JORGE ELIE HAYEK

\title{
AVALIAÇÃO DA DENSIDADE ÓTICA PERIMPLANTAR CERVICAL EM CONTROLE LONGITUDINAL DE IMPLANTES COM FUNÇÃO OCLUSAL IMEDIATA EM MAXILA
}




\section{Jorge Elie Hayek}

Avaliação da densidade ótica perimplantar cervical em controle longitudinal de implantes com função oclusal imediata em maxila

Tese apresentada à Faculdade de Odontologia da Universidade de São Paulo, para obter o título de Doutor pelo Programa de Pós-Graduação em Odontologia.

Área de Concentração: Diagnóstico Bucal

Orientador: Prof. Dr. Israel Chilvarquer

São Paulo

2005 
Catalogação-na-Publicação

Serviço de Documentação Odontológica

Faculdade de Odontologia da Universidade de São Paulo

Hayek, Jorge Elie

Avaliação da densidade ótica perimplantar cervical em controle longitudinal de implantes com função oclusal imediata em maxila / Jorge Elie Hayek; orientador Israel Chilvarquer. -- São Paulo, 2005.

126p. : tab., fig., graf., $30 \mathrm{~cm}$.

Tese (Doutorado - Programa de Pós-Graduação em Odontologia. Área de Concentração: Diagnóstico Bucal) -- Faculdade de Odontologia da Universidade de São Paulo.

1. Implante dentário endoósseo - osso alveolar perimplantar - Alterações 2 Radiografia periapical digitalizada 3. Diagnóstico bucal

AUTORIZO A REPRODUÇÃO E DIVULGAÇÃO TOTAL OU PARCIAL DESTE TRABALHO, POR QUALQUER MEIO CONVENCIONAL OU ELETRÔNICO, PARA FINS DE ESTUDO E PESQUISA, DESDE QUE CITADA A FONTE E COMUNICADO AO AUTOR A REFERÊNCIA DA CITAÇÃO.

São Paulo,

Assinatura:

E-mail: hayek@usp.br 


\section{FOLHA DE APROVAÇÃO}

Hayek JE. Avaliação da densidade ótica perimplantar cervical em controle longitudinal de implantes com função oclusal imediata em maxila [Tese de Doutorado]. São Paulo: Faculdade de Odontologia da USP; 2005.

São Paulo, /2005

\section{Banca Examinadora}

1) $\operatorname{Prof}(a) . \operatorname{Dr}(a)$.

Titulação:

Julgamento:

Assinatura:

2) $\operatorname{Prof}(a) . \operatorname{Dr}(a)$.

Titulação:

Julgamento:

Assinatura:

3) $\operatorname{Prof}(a) . \operatorname{Dr}(a)$

Titulação:

Julgamento:

Assinatura:

4) $\operatorname{Prof}(a) . \operatorname{Dr}(a)$.

Titulação:

Julgamento:

Assinatura:

5) $\operatorname{Prof}(a) . \operatorname{Dr}(a)$.

Titulação:

Julgamento:

Assinatura: 


\section{DEDICATÓRIA}

Aos meus queridos filhos Giovana (in memorian) e Bruno pela indescritivel e maravilhosa sensação de ser pai.

A querida Fernanda pelo apoio e colaboração na execução desta obra.

Aos meus amados irmãos, Michel e Vilma, pela compreensão nas minhas ausências e pela amizade que nos une.

Aos meus queridos pais, Elie (in memorian) e Latifa pelas oportunidades e estímulos nos estudos, por me ensinarem a viver e pelos inúmeros bons momentos que passamos juntos, muito obrigado. 


\section{AGRADECIMENTOS ESPECIAIS}

Ao Prof. Dr. Israel Chilvarquer, pelos exemplos de dedicação ao ensino e pesquisa, pela amizade demonstrada em todos os instantes e pela minha formação e aperfeiçoamento profissional, enfim por ser meu orientador.

À Prof. Dra. Lilian Waitman Chilvarquer pelo auxílio na execução deste trabalho e pelo apoio nos momentos importantes. 


\section{AGRADECIMENTOS}

Ao Prof. Dr. Jurandyr Panella, Professor Titular da Disciplina de Radiologia e Chefe do Departamento de Estomatologia, pelas oportunidades concedidas e pela amizade.

À Profa. Dra. Marlene Fenyo Soeiro de Matos Pereira, pela constante disposição em colaborar para aumentar nossos conhecimentos desde a graduação.

Ao Prof. Dr. Claudio de Freitas, por sua dedicação, competência, esforço e exemplo.

Ao Prof. Dr. Moacyr Domingos Novelli, pelos seus conhecimentos e pela ajuda na elaboração deste trabalho.

Ao Laboratório de Informática Dedicado à Odontologia (LIDO), pela utilização de suas dependências e equipamentos na realização deste trabalho.

Aos Professores da Disciplina de Radiologia da Faculdade de Odontologia da Universidade de São Paulo, pela amizade e conhecimento científico compartilhado.

Ao amigo Prof. Mario Sergio Saddy pelo companheirismo deste ultimos anos.

Aos colegas do Curso de Pós-Graduação em Radiologia pela amizade e companheirismo.

Ao Prof. Dr. Laércio Wonhrath Vasconcelos, Diretor Clínico do Brånemark Osseointegration Center -São Paulo pelo apoio e disponibilização das radiografias utilizadas neste trabalho. 
A Profa. Fernanda Bragança Albanese Hayek e Marcel Frederico de Lima Taga pela realização do estudo estatístico.

Aos pacientes pela disposição e colaboração demonstradas durante a execução dos exames radiográficos.

Ao serviço de Documentação Odontológica da FOUSP, pela presteza na realização deste trabalho. 
Hayek JE. Avaliação da densidade ótica perimplantar cervical em controle longitudinal de implantes com função oclusal imediata em maxila [Tese de Doutorado]. São Paulo: Faculdade de Odontologia da USP; 2005.

\section{RESUMO}

A proposta neste estudo foi avaliar as alterações da densidade ótica do osso alveolar perimplantar cervical em controle longitudinal, por meio de radiografias periapicais digitalizadas de dez pacientes, nos quais foram instalados seis implantes na maxila submetidos à função oclusal imediata, mediante a instalação de uma prótese fixa 24 horas após a cirurgia. Todos os pacientes foram avaliados clinicamente, com exames da análise da freqüência de ressonância, além de controle radiográfico. Foi utilizada a técnica radiográfica intrabucal do parale lismo, com cone longo, sendo que o feixe de raios $\mathrm{X}$ incidiu perpendicularmente ao longo eixo do implante. Os controles radiográficos foram realizados na instalação da prótese, após 6 meses e após 12 meses. As radiografias obtidas foram então capturadas por uma câmera de vídeo (preto e branco) por meio de um microscópio ótico (40 vezes de aumento). Devido à ampliação utilizada, os implantes tiveram suas imagens digitalizadas em 2 etapas (metade direita e metade esquerda), sendo consideradas como amostras independentes. Após a sobreposição de um gabarito sobre a imagem, com a finalidade padronizar as áreas a serem estudadas, foram analisadas as densidades óticas na área de interesse osso + implante e na área de controle implante (onde não é esperada alteração) por meio do software ImageLab. Para a correção de possíveis variações na densidade da radiografia e projeção geométrica oriundas da metodologia empregada, foi utilizada uma equação 
matemática para validar a análise dos dados obtidos. Os resultados mostraram que ocorreu variação percentual da densidade ótica na área de interesse (osso + implante) nos primeiros seis meses (T2) com diminuição de aproximadamente $5 \%$ para o lado direito e diminuição de aproximadamente $6 \%$ para o lado esquerdo em relação às radiografias iniciais $(\mathrm{T} 1)$ e após doze meses, a diminuição da densidade ótica estabilizou-se, não sendo encontradas alterações estatisticamente significantes em relação ao período correspondente entre T2 (seis meses) e T3 (doze meses). Os resultados da análise digital das radiografias periapicais demonstraram coincidência com os resultados da análise da freqüência de ressonância e exame clínico dos implantes e demonstraram um aspecto compatível com o sucesso dos implantes osteointegrados com função imediata na maxila.

Palavras-Chave: Implante osteointegrado - Função imediata - Carga imediata Controle radiográfico longitudinal - Processamento digital de imagens - Radiografias periapicais 
Hayek JE. Evaluation of the cervical perimplantar optical density in a longitudinal control of implants with immediate occlusion function in maxilla [Tese de Doutorado].

São Paulo: Faculdade de Odontologia da USP; 2005.

\section{ABSTRACT}

The aim in this study was the evaluation of the variations of the perimplantar optical bone density at the cervical region in a longitudinal control, by the use of digitized radiographs of ten patients, who received six implants installed in the maxilla and submitted to immediate occlusion function, through fixed prosthesis installed 24 hours after the surgery. All the patients were observed in clinical control, with resonance frequency analysis and also radiographic control. It was performed a intraoral radiograph using the paralleling technique, with the long cone and the beam of x-ray aimed perpendicular to the long axis of the implant. The radiographic controls were done at the time of the installation of the prosthesis, after six months and after twelve months after the first control. The obtained radiographs were captured by a black and white video camera by an optical microscope (40 times of magnification). Due to the utilized magnification, the implants have their images digitized in two steps: half right and half left, and they were considered as independent samples. After the superimposition of a standardized pattern, to help the standardization of the areas of the study, it was analyzed the optical density at the areas of interest bone + implant and at areas of control bone (where it is not hope changes) through the software ImageLab. To correct possible variations of the effect of the absence of standardization of the geometric projection and the radiographic density, it was realized a mathematic equation and it was obtained a correction factor of density in 
order to compensate. The results showed that there were percentage variation of the optical density at the area of interest (bone + implant) at six months (T2) showed a decreased of about $5 \%$ for the right side and showed a decreased of about $6 \%$ for the left side when analyzed the first control and after twelve months no significant statistical difference was observed between the T2 period (six months) and T3 period (twelve months). The results of digital analysis from the intraoral radiographs showed as the same as the results of resonance frequency analysis and the clinic examination of the implants and showed a success of implants installed in the maxilla with immediate occlusion function.

Keywords: Endosseous implants - Immediate occlusion function - Longitudinal radiographic control - Digital analysis - Intraoral radiographs 


\section{LISTA DE TABELAS}

Tabela 5.1 - Medidas descritivas das densidades óticas corrigidas da área de interesse osso + implante para cada um dos lados e nos períodos..... 88

Tabela 5.2 - Medidas descritivas da variação percentual da densidade ótica corrigida da área de interesse osso + implante dos períodos T2 e T3 em relação ao período $T 1$ 91

Tabela 5.3 - Medidas descritivas da variação percentual do segundo período (T2) em relação ao primeiro período (T1) (P2DOI e P2EOI) estratificados por aumento ou diminuição da densidade ótica corrigida da área de interesse osso + implante 92

Tabela 5.4 - Medidas descritivas da variação percentual do terceiro período (T3) em relação ao primeiro período (T1) (P3DOI e P3EOI) estratificados por aumento ou diminuição da densidade ótica corrigida da área de interesse osso + implante 92

Tabela 5.5 - Medidas descritivas da variação percentual do terceiro período (T3) em relação ao segundo período (T2) estratificados por aumento ou diminuição da densidade 93

Tabela 5.6 - Coeficientes de correlação entre as medidas das densidades óticas .. 94

Tabela 5.7 - Comparações entre os períodos (T1, T2 e T3) para a densidade ótica da área de interesse osso + implante para o lado direito do implante .95

Tabela 5.8 - Comparações entre os períodos (T1, T2 e T3) para a densidade ótica da área de interesse osso + implante para o lado esquerdo do implante 95 


\section{LISTA DE GRÁFICOS}

Gráfico 5.1 - Box Plot do percentual da densidade ótica da área de controle implante em relação à média das densidades óticas da área de controle implante do lado direito, com 57 dados amostrais

Gráfico 5.2 - Box Plot do percentual da densidade ótica da área de controle implante em relação à média das densidades óticas da área de controle implante do lado direito, sem os dados discrepantes 81

Gráfico 5.3 - Box Plot do percentual da densidade ótica da área de controle implante em relação à média das densidades óticas da área de controle implante do esquerdo, com 57 dados amostrais 82

Gráfico 5.4 - Box Plot do percentual da densidade ótica da área de controle implante em relação à média das densidades óticas da área de controleimplante do lado esquerdo, sem os dados discrepantes. 82

Gráfico 5.5 - Gráfico da densidade ótica da área de interesse (osso + implante) do lado direito (TiDOI onde $i=1,2,3$ ) sem correção e respectivas médias. 83

Gráfico 5.6 - Gráfico da densidade ótica da área de interesse (osso+implante) do lado esquerdo (TiEOI onde $i=1,2,3$ ) sem correção e respectivas médias. .84

Gráfico 5.7 - Gráfico da densidade ótica corrigida da área de interesse osso+ implante do lado direito (TiDOI Cor onde $i=1,2,3$ ) e respectivas médias 85 
Gráfico 5.8 - Gráfico da densidade ótica corrigida da área de interesse osso+ implante do lado esquerdo (TiEOI Cor onde $\mathrm{i}=1,2,3$ ) e respectivas médias 85

Gráfico 5.9 - Box plots da densidade osso + implante corrigida ao longo do tempo para os dois lados 86

Gráfico 5.10 - Box plots da variação percentual ao longo do tempo para os dois lados 87

Gráfico 5.11 - Histograma das variações percentual da densidade ótica na área de interesse osso + implante os primeiros 6 meses no lado direito 89

Gráfico 5.12 - Histograma das variações percentual da densidade ótica na área de interesse osso + implante os primeiros 6 meses no lado esquerdo 89

Gráfico 5.13 - Histograma das variações percentual da densidade ótica na área de interesse osso + implante nos 12 meses no lado direito 90

Gráfico 5.14 - Histograma das variações percentual da densidade ótica na área de interesse osso + implante nos 12 meses no lado esquerdo 90 


\section{LISTA DE FIGURAS}

Figura 4.1 - Radiografia panorâmica após a instalação dos implantes...................65

Figura 4.2 - Radiografias periapicais padronizadas.....................................65

Figura 4.3 - Câmera de vídeo acoplada ao microscópio ótico............................66

Figura 4.4 - Captura da imagem radiográfica do implante realizada em 2 etapas...67

Figura 4.5 - Sobreposição do gabarito.......................................................69

Figura 4.6 - União dos pontos do polígono.................................................70

Figura 4.7 - Seleção das áreas de interesse e de controle...............................71 


\section{LISTA DE ABREVIATURA E SIGLAS}

\begin{tabular}{|c|c|}
\hline BITS & dígito binário \\
\hline CCD & Charge Coupled Device \\
\hline $\mathrm{cm}$ & centímetro \\
\hline $\mathrm{KVp}$ & quiloVoltagempico \\
\hline LIDO & Laboratório dedicado a Odontologia \\
\hline $\mathrm{mA}$ & miliAmperagem \\
\hline $\mathrm{mg}$ & miligrama \\
\hline mGy & microGray \\
\hline $\min$ & minutos \\
\hline $\mathrm{mm}$ & milímetros \\
\hline Ncm & Newtons por centímetro \\
\hline$\mu \mathrm{m}$ & micrometro \\
\hline pixels & picture element \\
\hline $\mathrm{s}$ & segundos \\
\hline $3 D$ & tridimensional \\
\hline $\mathrm{T} 1$ & período T1 \\
\hline $\mathrm{T} 2$ & período T2 \\
\hline T3 & período T3 \\
\hline I & área de controle implante \\
\hline Ol & área de interesse osso + implante \\
\hline $\mathrm{D}$ & lado direito \\
\hline$E$ & lado esquerdo \\
\hline
\end{tabular}


DI lado direito da área de controle implante

El: $\quad$ lado esquerdo da área de controle implante

DOI: lado direito da área de interesse osso+implante

EOI: $\quad$ lado esquerdo da área de interesse osso+implante

T1DI densidade ótica no período 1 da área de controle implante na metade direita

T2DI densidade ótica no período 2 da área de controle implante na metade direita

T3DI densidade ótica no período 3 da área de controle implante na metade direita

T1DOI densidade ótica no período 1 da área de interesse osso + implante da metade direita

T2DOI densidade ótica no período 2 da área de interesse osso + implante da metade direita

T3DOI densidade ótica no período 3 da área de interesse osso + implante da metade direita

T1El densidade ótica no período 1 da área de controle implante na metade esquerda

T2El densidade ótica no período 2 da área de controle implante na metade esquerda

T3EI densidade ótica no período 3 da área de controle implante na metade esquerda

T1EOI densidade ótica no período 1 da área de interesse osso + implante da metade esquerda 
T2EOI densidade ótica no período 2 da área de interesse osso + implante da metade esquerda

T3EOI densidade ótica no período 3 da área de interesse osso + implante da metade esquerda

PorTiDI: $\quad$ porcentagem que a densidade ótica da área de controle implante no lado direito no período $\mathrm{i}$, onde $\mathrm{i}=$ período 1,2 ou 3

PorTiEl: $\quad$ porcentagem que a densidade ótica da área de controle implante no lado esquerdo no período $\mathrm{i}$, onde $\mathrm{i}=$ período 1,2 ou 3

T1DOICor densidade ótica no período 1 da área de interesse osso + implante da metade direita corrigida

T2DOICor densidade ótica no período 2 da área de interesse osso + implante da metade direita corrigida

T3DOICor densidade ótica no período 3 da área de interesse osso + implante da metade direita corrigida

T1EOICor densidade ótica no período 1 da área de interesse osso + implante da metade esquerda corrigida

T2EOICor densidade ótica no período 2 da área de interesse osso + implante da metade esquerda corrigida

T3EOICor densidade ótica no período 3 da área de interesse osso + implante da metade esquerda corrigida

P1DOI variação percentual da densidade ótica na área de interesse osso + implante da metade direita nos primeiros 6 meses

P1EOI variação percentual da densidade na área de interesse osso + implante da metade esquerda nos primeiros 6 meses 
P2DOI variação percentual da densidade na área de interesse osso + implante da metade direita nos últimos 12 meses

P2EOI variação percentual da densidade na área de interesse osso + implante da metade esquerda nos últimos 12 meses 


\section{SUMÁRIO}

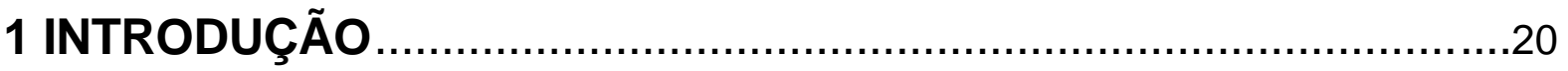

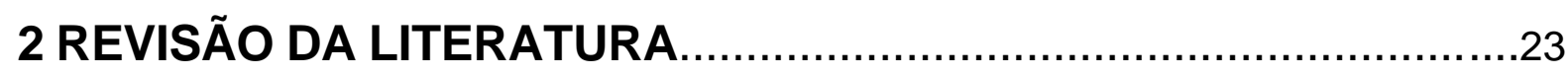

2.1 Aspectos radiográficos dos implantes, suas alterações, metodologia de aquisição e manipulação de imagens......................................23

2.2 Implantes: função e / ou carga imediata....................................49

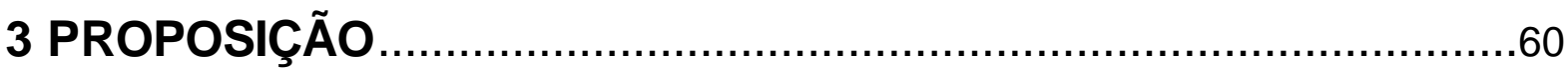

4 CASUÍSTICA-MATERIAL E MÉTODOS....................................61

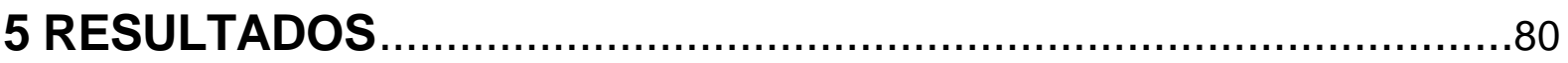

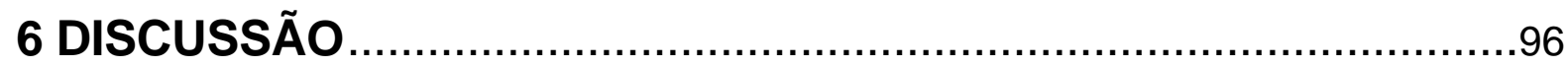

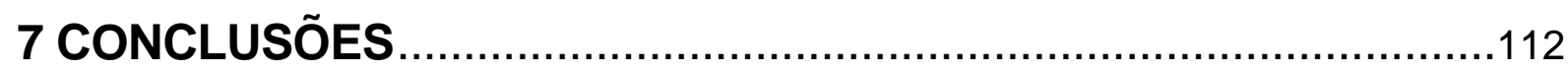

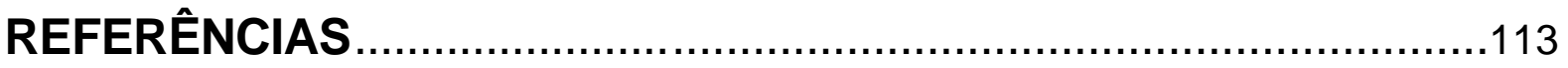

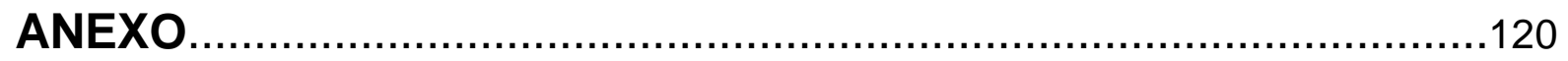

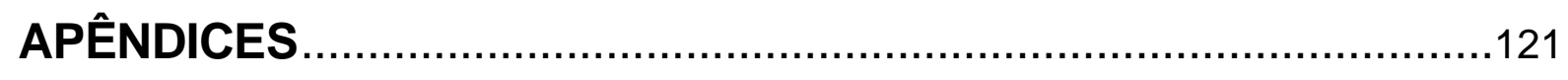




\section{INTRODUÇÃO}

A perda da dentição leva os pacientes, na maioria das vezes, a problemas morfo-funcionais e alterações patológicas que com o passar do tempo, se agravam, pela contínua perda óssea causada pela falta de estimulo funcional e ou trauma das próteses removíveis totais e parciais (VASCONCELOS, 2004).

A perda dental e óssea alveolar e a conseqüente necessidade de se usar próteses podem afetar a sociabilidade dos pacientes, assim como dificultar a mastigação, gerando problemas de digestão, aproveitamento de proteínas, o que debilita ainda mais os pacientes, principalmente os mais idosos (SOUZA PINTO, 2004).

A colocação de implantes osteointegrados mantém o processo alveolar, tanto em altura como em espessura, o que é importante para o resultado protético final Vasconcelos et al. (2005).

O tratamento realizado com a fase cirúrgica em dois tempos foi idealizado para que tanto os casos com boas condições anatômicas e qualidade óssea fossem tratados igualmente aos casos onde a anatomia e a qualidade óssea não fossem ideais. Isso possibilitou o sucesso da osteointegração, que alcança índices de previsibilidade entre 95 e $98 \%$ em mandíbulas com acompanhamento acima de 10 anos (ADELL et al., 1990).

Após o comprovado sucesso na mandíbula, a osteointegração passou a ser utilizada em maxilas desdentadas e em casos parciais e unitários, com boa previsibilidade (BAHAT, 2000). 
Brånemark et al. (1999) publicaram o protocolo The Brånemark Novum Protocol for the Same Day Teeth onde é descrita uma técnica de colocação de três implantes na mandíbula com carga imediata. Apresentaram um protocolo cirúrgico protético que permite a colocação dos implantes após seis ou 8 horas da cirurgia, instalavam as proteses .

A carga imediata trouxe para os profissionais e pacientes, muitas vantagens, pois possibilita a diminuição dos custos, evita uma segunda intervenção e diminui o tempo de tratamento. No entanto, a maioria das publicações e dos estudos clínicos tem ocorrido quando esta técnica é aplicada na mandíbula (VASCONCELOS et al., 2005).

A maxila apresenta situações anatômicas e de qualidade óssea diferente da mandíbula.

As radiografias realizadas no exame pré-cirúrgico de implantes têm como finalidade a avaliação da quantidade e qualidade do tecido ósseo, localização dos reparos anatômicos em relação aos locais onde se planeja realizar os implantes, a presença ou não de lesões ósseas nessas regiões e a determinação do posicionamento e quantidade de implantes a serem colocados. São utilizadas com essa finalidade as radiografias periapicais, panorâmicas e tomografias (lineares, hipocicloidais, circulares e computadorizadas) (CHILVARQUER, 1993).

Já a realização do exame radiográfico pós-cirúrgico é necessária para a verificação da posição e alinhamento dos implantes, adaptação dos pilares às fixações, avaliação da altura e densidade óssea ao redor dos implantes e fratura do parafuso do pilar ou da fixação dos implantes. Para atingir estes objetivos são utilizadas radiografias periapicais e panorâmicas. (CHILVARQUER, 1997; GRÖNDAHL; EKESTUBBE; GRÖNDAHL, 1996b). 
Desde a década de 90 são utilizados para a avaliação longitudinal de implantes odontológicos, os chamados métodos convencionais, digital direto e digitais com captação indireta. Sendo que cada vez mais a metodologia é mais utilizada (GRÖNDAHL; EKESTUBBE; GRÖNDAHL, 1996a; HAYEK, 2002).

O objetivo neste trabalho é avaliar a densidade ótica perimplantar em maxilas com edentulismo total e que foram reabilitadas com implantes com função imediata, com o intuito de estudar a resposta óssea frente a essa nova modalidade terapêutica, auxiliando no diagnóstico precoce de possíveis perdas ósseas. 


\section{REVISÃO DA LITERATURA}

Este capítulo tem como objetivo apresentar conceitos em relação às imagens radiográficas de implantes osteointegrados, suas alterações decorrentes de perdas ósseas, bem como métodos de aquisição e manipulação de imagens. Por fim, são apresentados artigos referentes a implantes onde foram utilizadas as técnicas de função e / ou carga imediata.

\subsection{Aspectos radiográficos dos implantes, suas alterações, metodologia de aquisição e manipulação de imagens}

Brånemark et al. (1977), após realizarem controle de 10 anos, com 211 casos tratados descreveram um novo procedimento para reabilitação de pacientes edêntulos através de próteses suportadas por implantes de titânio osteointegrados. Foi efetuado um controle radiográfico pós-cirúrgico anual por meio da técnica periapical, utilizando um suporte de Eggen. Concluíram que existe uma relação direta entre a presença de uma área radiolúcida perimplantar e a mobilidade clínica do implante, na radiografia periapical. Os autores verificaram que durante a fase reparação, houve uma redução da altura óssea perimplantar de 1 a $2 \mathrm{~mm}$ (ao redor de 9 meses). Enquanto que na fase de remodelação ocorreu uma perda de 0,2 a 0,3mm por ano na altura óssea marginal. Esta fase se inicia durante a fase de reparação e dura em torno de 18 meses.

Hollender e Rockler (1980), por meio de estudo radiográfico realizado em modelos de mandíbula, estaram a precisão do exame radiográfico periapical na 
avaliação dos implantes. Foram utilizados três modelos de mandíbula feitos com cortical e osso esponjoso de elefante com dimensões correspondentes as de mandíbula humana edêntula, com a porção de osso trabecular contendo 7 a $8 \mathrm{~mm}$ e as corticais com $2 \mathrm{~mm}$ de espessura, onde foram colocados 13 implantes do Tipo Brånemark e simulados defeitos ósseos, através de remoções de tecido ósseo ao redor dos implantes para aparentar a presença de bolsas infra-ósseas. As radiografias foram realizadas com e sem a presença das corticais ósseas, para simular diferenças existentes entre as mandíbulas humanas e variando as angulações horizontal e vertical dos raios $\mathrm{X}$. Os autores concluíram que a variação da angulação vertical dos raios $X$ exerce grande influência na avaliação do tecido ósseo perimplantar. Quando a variação do ângulo vertical é a partir de $9^{\circ}$ de desvio em relação à incidência perpendicular à fixação, as porções mais internas das espiras dos implantes não são mais observadas e quando esta variação ultrapassar $13^{\circ}$ de desvio, as porções mais externas das espiras tornam-se pouco discerníveis. Os autores citaram que quanto mais espesso for o rebordo ósseo, maior o risco de uma avaliação inadequada do nível ósseo perimplantar.

Adell et al. (1981) realizaram um acompanhamento de 15 anos em pacientes submetidos a implantes osteointegrados, analisando os tecidos moles circunjacentes, a osteointegração e a altura óssea. No exame radiográfico, observaram que as perdas ósseas que ocorreram nas fases de reparação e remodelamento em média eram de aproximadamente $1,2 \mathrm{~mm}$ e que nos anos seguintes de $0,1 \mathrm{~mm}$. Os autores concluíram que os implantes com mobilidade apresentavam imagens radiolúcidas perimplantares, enquanto que os implantes que clinicamente estavam estáveis, mantinham um íntimo contato com tecido ósseo 
adjacente, sendo que em alguns implantes foi encontrado um aumento da densidade óssea que foi atribuído à incidência de cargas funcionais.

Baxes (1984), comentou conceitos fundamentais para a compreensão dos trabalhos que empregam processamento digital de imagens, os quais de maneira geral, referem-se às alterações e análises da imagem, com o objetivo de intensificar visualmente ou avaliar estatisticamente algum aspecto de uma imagem. São utilizadas três técnicas: o processamento ótico, o processamento analógico e o processamento digital.

Webber, Ruttiman e Groenhuis (1984), devido às distorções das imagens radiográficas causadas por erro no posicionamento do filme em relação à fonte de raios $X$, que interferem quando da realização da subtração radiográfica, propuseram um método de correção das distorções de projeção em radiografias dentais através do computador. O método localiza pontos de referência conhecidos de uma imagem dentro de pontos homólogos na outra imagem. As imagens podem então ser sobrepostas e subtraídas com uma significativa redução das diferenças de registro.

Strid (1985), estabeleceu parâmetros para que todas as radiografias sejam obtidas de maneira padronizada para possibilitar comparações com exames radiográficos dos implantes em épocas diferentes. A técnica radiográfica a ser utilizada é a técnica periapical do tipo paralelismo, com o filme colocado paralelo ao longo eixo do implante e o feixe principal de raios $\mathrm{X}$ incidindo perpendicularmente a esse eixo, com o regime de trabalho do aparelho de raios $\mathrm{X}$, operando entre 65 e 70 $k V p$, não sendo menor que $60 \mathrm{kVp}$ e recomenda-se o uso de suporte de Eggen ou de Rockler. Cita que em rebordos alveolares extremamente reabsorvidos, devido ao desconforto causado ao paciente no posicionamento do filme e a possibilidade de dobras ou curvaturas, a porção apical do implante pode ser excluída da área da 
imagem, sendo necessário observar ao menos $3 \mathrm{~mm}$ de osso marginal ao longo do implante (porção coronária do implante). Como periodicidade do exame radiográfico, o autor propõe imediatamente após a colocação da prótese, 6 meses, 12 meses e 3 anos após, e a cada 3 anos. Recomenda não realizar a tomada radiográfica antes da colocação da prótese devido ao fato de que não serão obtidas informações radiográficas que tenham utilidade clínica e a possibilidade de uma resposta desfavorável do tecido ósseo em processo de reparação devido à radiação ionizante. Conclui que o exame radiográfico é o único meio de análise do implante não invasivo, citando que um implante clinicamente estável é caracterizado por imagem de osso normal em íntimo contato com a superfície metálica da fixação e a presença de imagem radiolúcida perimplantar é indicativa de mobilidade do implante.

Cox e Pharoah (1986), desenvolveram um suporte porta filmes, adaptável ao suporte "Rinn" que possibilitava a reprodutibilidade das radiografias periapicais nos paciente portadores de implantes osteointegrados na Universidade de Toronto, Canadá. O suporte era construído de resina acrílica autopolimerizável incolor, feito com tamanhos diferentes e foi desenhado para ser preso ao abutment do implante, sendo necessário que a prótese do paciente fosse removida. O suporte permitia a estandardização densitométrica através de uma escala de alumínio.

Ruttimann, Webber e Schmidt (1986), citaram que as variações da imagem radiográfica causadas, por posicionamento de filme e raios $\mathrm{X}$ e alterações de exposição e processamento dos filmes, nos estudos longitudinais realizados com subtração radiográfica, devem ser as menores possíveis. Os autores apresentaram um método digital que produz a transformação única e monotônica dos níveis de 
cinza diretamente a partir dos histogramas associados com as radiografias para obter a correção das diferenças de contraste em radiografias a serem subtraídas.

Smith e Zarb (1989), citaram novos critérios para avaliação do sucesso de implantes osteointegrados. Entre os critérios clínicos sugeridos, estavam a presença de mobilidade, profundidade do sulco, saúde gengival, presença de infecção, perda óssea marginal, conforto do paciente, aparência estética, penetração no seio maxilar, canal mandibular ou assoalho da fossa nasal e durabilidade do trabalho. Relataram que a radiografia periapical fornece uma imagem bidimensional de uma estrutura tridimensional, possibilitando verificar as faces mesial e distal do implante, mas não permitindo a avaliação das faces vestibular e lingual. A presença de radiolucidez ao redor do implante sugere a existência de tecido mole e a provável ocorrência de mobilidade que será verificada com a remoção da supra estrutura protética, nos casos onde haja vários implantes. A estabilidade do suporte ósseo é importante para determinação de sucesso do implante. Com o passar do tempo, nos casos de implante bem sucedido, o contato ósseo aumenta, enquanto na presença de cargas oclusais excessivas, a quantidade de contato ósseo diminui, podendo perder a osteointegração. Consideram aceitável uma perda óssea anual menor que 0,2 mm após o primeiro ano de função da prótese. Os autores revisando a literatura sugerem que para a correta avaliação radiográfica, o feixe de raios $X$ central deve incidir perpendicularmente ao implante e ao filme.

Sewerin (1990), por meio de um trabalho experimental, avaliou a influência da angulação vertical dos raios $\mathrm{X}$ e da espessura vestíbulo-lingual do rebordo ósseo nas medidas da altura óssea perimplantar realizadas em radiografias periapicais. Utilizou blocos de acrílico de diferentes espessuras, que simularam rebordos alveolares de 5, 9, 11 e 13mm de dimensão vestíbulo-lingual e colocou implantes de 
titânio do tipo Brånemark. $\mathrm{O}$ autor variou a angulação vertical dos raios $\mathrm{X}$ de $0^{\circ}$ (perpendicular), $5^{\circ}, 1^{\circ}, 1^{\circ}$ e $20^{\circ}$ e verificou que em pequenos desvios da angulação vertical, a precisão da mensuração óssea fica comprometida e que os diferentes tipos de rebordo ósseo influenciam a interpretação.

Adell et al. (1990) citaram que o exame radiográfico isoladamente nem sempre pode ser conclusivo na avaliação da osteointegração. Realizaram estudo radiográfico em 23 pacientes que receberam implantes osteointegrados (188 áreas) com enxertos autógenos cortico-esponjosos de osso ilíaco e encontraram 5 áreas de 4 implantes com menor densidade no osso perimplantar em relação ao osso mais periférico, mas em apenas dois destes implantes foi confirmada a mobilidade clínica em testes individuais. Os autores sugeriram que os implantes com áreas radiolúcidas perimplantares, mas sem mobilidade clínica, podem não estar osteointegrados nas faces proximais, mas nas faces vestibular e lingual ter mantido a osteointegração.

Stenström et al. (1990), realizaram estudo para verificar se o exame radiográfico após a instalação cirúrgica dos implantes até a conexão dos pilares deveria ser considerado contra-indicado, em relação ao risco de dano celular, devido à excessiva liberação de elétrons secundários do metal, ocorrida após a exposição, multiplicando a dose de radiação por aproximadamente 25 vezes nos limites entre metal e osso. Os autores utilizaram um modelo teórico, onde foi calculado que o osso imediatamente perimplantado seria exposto a elétrons secundários com uma dose de $27 \mathrm{mGy}$, que poderia dobrar no espaço entre 2 espiras do implante. A distância do osso exposto por elétrons secundários parece ser limitada a $20 \mu \mathrm{m}$ a partir da superfície do implante. E a partir de $8 \mu \mathrm{m}$ da superfície do implante foi calculado que a dose absorvida era menor que 1mGy. Os autores concluíram serem 
extremamente improváveis os danos somáticos em uma dose pequena de exposição aos raios $\mathrm{X}$.

Reddy, Jeffcoat e Richardson (1990), utilizaram a subtração radiográfica digital com o intuito de detectar pequenas alterações na altura e densidade óssea no período de reparação em pacientes que receberam implantes cilíndricos, como também compararem a utilização de flurbiprofen (antiinflamatório não esteroidal) em pacientes em relação ao suporte ósseo do redor de implantes em pacientes que não fizeram uso desta droga. Foram realizadas radiografias padronizadas no pósoperatório imediato e 4 meses após, com o uso de um cefalostato e distância focofilme de aproximadamente $127 \mathrm{~cm}$. As radiografias foram convertidas em imagens digitalizadas por meio de um sistema de circuito fechado de vídeo acoplado a um conversor analógico para digital, em um microcomputador. As diferenças de contrastes e discrepâncias geométricas foram corrigidas por algorítmico apropriado e o resultado da subtração de imagens mostrado em um monitor de vídeo e fotografado com uma câmara computadorizada de $35 \mathrm{~mm}$. Um examinador analisou as imagens, e os resultados indicaram que a subtração de imagens evidenciou aumento de densidade óssea na região das espiras da fixação nos pacientes testes, enquanto não foi observado perda ou ganho ósseo nos pacientes controlados. Segundo os autores, a subtração radiográfica digital é importante na avaliação óssea perimplantar e que a administração sistêmica do antibiótico não esteroidal flubirpofen pode estar associada ao aumento de densidade óssea durante a fase inicial de reparação óssea perimplantar.

Van Der Stelt e Geraets (1991) realizaram um trabalho para verificar e quantificar os defeitos ósseos angulares observados em radiografias com o auxílio do computador. Os autores relataram que a capacidade do observador humano em 
detectar e definir pequenos defeitos ósseos é limitada, e o processamento digital da imagem pode fornecer uma valiosa contribuição no processo de diagnóstico. Compararam os dados de uma inspeção cirúrgica de lesões ósseas, com os resultados dos procedimentos digitais e concluíram que estes forneceram informações confiáveis em relação ao tamanho das lesões.

Brägger et al. (1991), por meio de subtração digital entre radiografias padronizadas de controle longitudinal de implantes, avaliaram as modificações de densidade radiográfica dos tecidos perimplantares. Realizaram fotografias digitalizadas das radiografias por meio de uma câmara CCD preto e branco. Inicialmente era feito o alinhamento de cada radiografia padronizada com a radiografia inicial, sendo compensadas as diferenças de densidade, após a comparação de histogramas dos níveis de cinzas das duas imagens, por meio de correção de contraste, descrito por Ruttimann, Webber e Schmidt (1986), que não permitia correções na projeção das imagens decorrentes de dobras do filme durante a tomada radiográfica. Dentro das imagens subtraídas foram estabelecidas regiões de interesse, sendo áreas de controle onde não era esperada modificação (espaço interoclusal) e área de teste nas quais alterações poderiam ocorrer (osso perimplantar). As avaliações foram feitas pixel por pixel, indicando informações do histograma dos níveis de cinza, seus valores médios e desvios padrões. Os autores por meio da subtração radiográfica digital verificaram que as alterações ósseas ocorridas no osso perimplantar podem ser acentuadas visualmente. Concluíram que a utilização do método de subtração radiográfico digital, com radiografias estandardizadas, pode ser um dos métodos mais sensitivos e não invasivos para diagnóstico de alterações precoces da densidade dos tecidos perimplantares. 
Wenzel (1991) realizou estudo sobre a influência da informática na qualidade radiográfica das imagens intrabucais, onde citou que a maioria dos parâmetros relevantes para o controle de qualidade de imagem na radiografia convencional não são úteis em relação à técnica digital. O borramento da imagem está relacionado no filme ao tamanho dos grãos halogenados de prata, enquanto que, na imagem digital, isto se dá pela resolução da matriz. O autor relatou que cada um dos parâmetros que define qualidade de imagem, ou seja, contraste, borramento e ruído, pode ser alterado digitalmente. A capacidade de um ajuste digital da densidade e do contraste da imagem pode resultar em um menor número de exames e repetições, resguardando o paciente em relação à dose, pois radiografias com baixa densidade podem ser manipuladas tendo um ganho suficiente de contraste. Além disso, uma radiografia de determinada densidade pode ter seu brilho e seu contraste ajustados de acordo com a conveniência da tarefa específica de diagnóstico.

Com o propósito de comparar o diagnóstico obtido por meio de radiografias realizadas com o filme Ultra-Speed e com o filme Ektaspeed (Eastman Kodak Co.) quando analisadas convencionalmente e após o processo de subtração radiográfica digital, Nicopoulou-Karayianni et al. (1991) criaram lesões ósseas através de brocas (em baixa rotação) medindo 0,$5 ; 0,7 ; 0,9$ e $1,1 \mathrm{~mm}$ de diâmetro nos quatro quadrantes de um crânio seco, na região da crista interdental entre o $1^{\circ}$ pré molar e 2 o molar; por vestibular e lingual. As radiografias foram padronizadas através de uma modificação no posicionador do sistema Rinn e obtidas antes e após os defeitos. Com a exceção do tempo de exposição (o filme Ektaspped com cerca de redução de $50 \%$ no tempo de exposição em relação ao utilizado para o filme Ultra-Speed), todos os fatores de exposição e processamento radiográficos foram idênticos. A medida que o tamanho das lesões ósseas foi aumentando, novas radiografias foram 
realizadas. As radiografias foram digitalizadas através de um câmera preta e branca, alinhadas e após a melhor superposição possível foram corrigidas algumas mudanças na densidade causadas por diferentes condições de exposição e/ou processamento. Posteriormente ao ajustes nos histogramas de tons de cinza, a subtração digital foi realizada. Os resultados foram analisados por quatro dentistas e demonstraram que a sensitividade em detectar as lesões foi dobrada após a digitalização e a subtração das imagens quando comparadas com a interpretação radiográfica convencional, independente do uso de filme Ektaspeed ou Ultra-Speed na radiografia original.

Hollender (1992) recomendou que a incidência dos raios X seja direcionada perpendicularmente ao longo eixo dos implantes, para que os passos de espiras da fixação possam servir como referência para controle das alterações ósseas perimplantares em acompanhamento longitudinal. Nos casos em que as condições anatômicas não permitem o posicionamento correto do filme ao longo de toda a extensão da fixação, o exame deve se restringir às regiões mais próximas à crista óssea alveolar. Quanto ao exame radiográfico periapical, citou que é possível saber qual é a correção necessária na angulação vertical dos raios $\mathrm{X}$ para ficarem nítidas as espiras dos implantes. Quando o desvio na inclinação do feixe de raios $\mathrm{X}$ for maior que $13^{\circ}$, o contorno das espiras perde definição na imagem radiográfica. Nos casos onde o feixe principal de raios $\mathrm{X}$ for direcionado com ângulo vertical maior que a ideal, as espiras irão se apresentar com menor detalhe do lado direito do que as do lado esquerdo, do ponto de vista do observador, na maxila e na mandíbula. Se o feixe de raios $X$ tiver angulação menor que a ideal, as espiras do lado esquerdo vão perder detalhe. Acrescentou que variações na angulação horizontal do feixe de raios $X$ entre um e outro exame radiográfico podem provocar a sobreposição de diferentes 
porções da crista óssea alveolar, dando alterações na interpretação. Assim como a inclinação do implante em relação à crista óssea alveolar pode levar a uma falsa impressão da quantidade de suporte ósseo integrado à fixação. Cita que suportes especiais porta-filme, para acompanhamento longitudinal tem sido indicados, mas devido à necessidade de remoção da prótese fixa ou confecção de suportes individuais, não obtiveram popularidade. Relata que imagens digitalizadas obtidas através de radiografias convencionais ou obtidas diretamente auxiliam a interpretação e avaliação da densidade ótica do osso perimplantar. Recomendou que o exame radiográfico deva ser executado de 6 em 6 meses, no primeiro ano, após um ano e seguido por intervalos de 2 a 3 anos.

Meijer, Steen e Bosman (1992), propuseram a padronização do exame radiográfico periapical longitudinal de implantes na região anterior da mandíbula, por meio de um suporte porta-filme preso diretamente aos pilares dos implantes. 0 suporte necessitava para sua estabilização, que os pilares possuíssem diâmetro entre 3,5 e $5 \mathrm{~mm}$ e altura supra-gengival de no mínimo 3,5mm. Foi testado em 4 diferentes sistemas de implantes e os autores concluíram que o método é adequado para controle radiográfico de implantes dentários.

Brägger et al. (1992), citaram que os parâmetros radiográficos utilizados para avaliação de implantes odontológicos em uso eram: avaliação de alterações na altura óssea perimplantar; análise desta altura através do computador; avaliação da qualidade óssea perimplantar; e verificação do conteúdo mineral ósseo, por fotoabsormetria. Lembraram que as radiografias convencionais possuem alta especificidade, mas baixa sensitividade na detecção de alterações perimplantares e descreveram procedimentos de processamento de imagens na avaliação de implantes odontológicos, feitos com o mesmo equipamento e metodologia do 
trabalho anterior. A subtração digital de imagens de uma região sem alterações de densidade deve apresentar, preferencialmente, um perfeito cancelamento das estruturas, e cada "pixel" deve ter um valor de nível de cinza igual a 128, que é correspondente ao centro da faixa estabelecida pelo programa. $\mathrm{Na}$ análise das imagens, áreas com níveis de cinza menores que 128 na subtração aparecem escuras sobre um fundo de 128 , demonstrando uma perda de densidade, enquanto áreas com níveis maiores que 128 apareceram claras, indicando um aumento de densidade. Através de conversão de alguns níveis de cinza para pseudo-cores, dentro da imagem subtraída, notaram um realce das modificações precoces de densidade. Os autores concluíram que o método descrito de processamento de imagens pode incrementar o diagnóstico precoce na remodelação óssea após a colocação de implantes odontológicos devido às cargas mastigatórias funcionais ou na perda da osteointegração, antes que estas alterações ósseas tornem-se clínicas ou radiograficamente evidentes.

Jeffcoat (1992), preconizou o uso da subtração radiográfica para avaliação de implantes longitudinal, o qual depende da padronização do contraste e da geometria das radiografias. A correção de contraste pode ser feita pelo algoritmo não paramétrico de correção de Ruttimann, Webber e Schmidt (1986) enquanto a padronização geométrica da radiografia pode ser obtida por suportes que fisicamente posicionam a fonte de raios $\mathrm{X}$, objeto e filme ou por cefalostatos. $\mathrm{O}$ autor concluiu que as informações relativas aos níveis de cinza da imagem subtraída, podia fornecer uma avaliação quantitativa da perda ou ganho ósseo perimplantar durante as fases de reparação, remodelação ou de função.

Chilvarquer (1993), ressaltou a importância do planejamento radiográfico para implantes, por meio de tomografias lineares para mensurar a altura e espessura do 
rebordo ósseo da maxila e da mandíbula. Citou que a radiografia panorâmica é importante para a avaliação pré e pós operatória de implantes osseointegrados, quando tecnicamente bem executada.

Jeffcoat e Reddy (1993) descreveram o método de subtração radiográfica utilizado em seu laboratório para avaliação longitudinal de implantes osteointegrados. A descrição do método consiste em obter radiografias padronizadas realizadas em exames diferentes que posteriormente serão digitalizadas. A subtração radiográfica tem como vantagem isolar a área com alteração óssea, superposição desta área na radiografia inicial para facilitar a visão da região alterada e quantificar a alteração em termos de massa. Todas as estruturas que não sofreram alterações entre os exames como os implantes, aparecem em um fundo neutro. Por convenção, áreas com perda óssea aparecem em tons escuros de cinza e áreas com ganho ósseo aparecem mais claras que o fundo neutro. A utilização de uma escala de referência de alumínio no espaço interoclusal facilita o cálculo da soma da alteração óssea e não fornece referência para correção no contraste e densidade da imagem. A escala de referência é utilizada somente na radiografia inicial que é subtraída da radiografia realizada no controle posterior. A imagem subtraída contém a imagem da alteração óssea e a imagem negativa da escala de referência. A imagem negativa da escala é usada para determinar a espessura da escala que corresponde à mudança nos níveis de cinza da alteração óssea. As áreas com ganho ou perda óssea são isoladas e o sinal é convertido em uma imagem binária (preta ou branca sem tons de cinza). Para o cálculo das alterações ósseas, multiplica-se a (área $x$ espessura $x$ densidade do alumínio x fator de conversão da densidade do alumínio para o osso). Os autores citam que este cálculo nem sempre fornece medidas absolutas das alterações 
ósseas devido a erros não lineares. Para validar o método de subtração radiográfica digital, realizaram radiografias em diferentes regiões da boca em macacos. Seis pequenos chips ósseos com massa variando entre 5 e $54 \mathrm{mg}$ foram fixados ao filme. A primeira radiografia foi realizada com o chip ósseo e a escala de referência de alumínio e o segundo filme foi realizado removendo o chip (simulando uma lesão)e a escala. As radiografias foram subtraídas pelo método acima descrito. O resultado entre a massa da lesão e a massa real do chip mostrou uma excelente correlação $\left(R^{2}=0,99\right)$. Os autores ressaltam que a alta qualidade e padronização dos filmes são essenciais para o sucesso da implementação da técnica que pode facilitar o controle dos implantes dentários

Fourmousis et al. (1994), por meio de um estudo in vitro, avaliaram a quantidade de alterações de densidade em imagens por subtração digital que eram provocadas por ruído eletrônico (transformação de uma radiografia analógica para uma imagem digitalizada) e por erros de alinhamento na sobreposição de duas imagens radiográficas. Utilizaram uma mandíbula de porco, onde foi instalado um implante ITI Bonefit@ de 10 milímetros. Após séries de radiografias padronizadas obtidas, com diferentes tempos de exposição $(0,34 ; 0,39 ; 0,44 ; 0,51$ e 0,58 seg.), suas imagens foram capturadas por uma câmera de vídeo preto e branco, digitalizadas através de uma placa de captura de imagens e armazenadas em um computador. O ruído devido à transformação analógica para digital foi calculado em aproximadamente dois níveis de cinza, ou seja, $2 \%$ da escala. Este tipo de erro foi reduzido em até $40 \%$, capturando as imagens mais de uma vez e estabelecendo as médias dos valores por pixel. Em relação a sobreposição manual das imagens a serem subtraídas, o erro foi calculado em mais ou menos 3 níveis de cinza (2,7 da escala). Os autores concluíram que os ruídos eletrônicos e de sobreposição devem 
ser considerados antes de qualquer avaliação qualitativa ou quantitativa de imagens por subtração digital.

Ludlow, Gates e Nason Jr (1995), avaliaram a precisão do diagnóstico da perda óssea nas faces vestibular e lingual de implantes odontológicos por meio das técnicas radiográficas periapical, oclusal e tomográfica. A técnica radiográfica periapical fornece informações diagnosticas das faces mesial e distal dos implantes, enquanto que aproximadamente metade do suporte ósseo, correspondente às faces vestibular e lingual, devido às sobreposições da imagem radiopaca da fixação, permanece obscurecida na radiografia. Foram colocados 3 implantes de titânio em uma mandíbula seca nas regiões de incisivo pré-molar, e molar onde foram simuladas perdas ósseas ao redor dos implantes com o uso de brocas esféricas de diâmetro crescente. Os autores realizaram radiografias periapicais, oclusais e tomográficas que foram avaliadas por œis dentistas, para verificar a presença ou ausência de alteração de densidade óssea nas regiões vestibular e lingual dos implantes. A análise foi realizada quanto à sensitividade (número de todas as observações corretas da presença das lesões dividido pelo número real de lesões), especificidade (número de todas as observações corretas de ausência de lesão dividido pelo número de situações onde a lesão não estava efetivamente presente) e precisão (número de todas as observações corretas dividido pelo número total de observações possíveis). Os resultados sugeriram que as imagens obtidas pela técnica radiográfica periapical convencional não permitiram a detecção de perda óssea nas faces vestibular e lingual dos implantes. As radiografias oclusais ofereceram sensitividade e especificidade satisfatória. Os autores alertaram para o fato de ter sido utilizado um modelo com mandíbula seca, onde devido a ausência de tecidos moles, foram obtidos um nível de detalhe e contraste radiográfico superior 
obtido em um modelo em vivo. As tomografias apresentaram baixa sensitividade em pequenas perdas ósseas, mas foram superiores as radiografias oclusais, quando os defeitos ósseos apresentavam maior diâmetro. Os autores concluíram que as técnicas tomográficas associadas a subtração digital podem contribuir para o melhor diagnóstico de alterações ósseas nas faces vestibular e lingual dos implantes.

Ludlow et al. (1995), por meio da digitalização, subtração e manipulação de contraste de imagens, compararam as técnicas periapical e tomográfica para melhor avaliação da capacidade de detecção de perda óssea nas faces vestibular e lingual de implantes de Titânio, utilizando metodologia semelhante ao do trabalho anterior. A cada perda óssea simulada, foram obtidas radiografias periapicais e tomografias. As radiografias foram digitalizadas em escala de 256 níveis de cinza e as subtrações foram realizadas com o software Image. As faces mesial e distal das fixações foram cobertas para centralizar a atenção dos observadores (oito) apenas nas faces vestibular e lingual. A manipulação das projeções periapicais não foi suficiente para permitir a detecção de perda óssea nas faces vestibular e lingual. A comparação por subtração de tomografias pode incrementar o diagnóstico de alterações iniciais nas faces vestibular e lingual de implantes, apesar do tempo despendido na digitalização e subtração de imagens, concluíram os autores.

Kullendorff e Nilsson (1996) verificaram em um trabalho experimental, a precisão das radiografias digitais no diagnóstico de lesões ósseas periapicais, por meio de um estudo comparativo entre a imagem radiográfica digital em sua forma original e imagem radiográfica manipulada com as facilidades dos recursos digitais. Os autores concluíram que não foi observada diferença entre as duas imagens em relação à precisão no diagnóstico. Ressaltaram que o processamento da imagem foi mais efetivo com a manipulação do brilho e do contraste e que os outros 
procedimentos disponíveis para a manipulação das imagens radiográficas tiveram um menor efeito na precisão do diagnóstico.

Kullendorff, Nilsson e Rohlin (1996) verificaram a precisão das radiografias digitais no diagnóstico de pequenas lesões ósseas periapicais, por meio de um estudo experimental comparativo entre a imagem radiográfica do filme Ektaspped e a imagem radiográfica digital direta do sistema CCD, Visualix-Vixa. Foram examinadas as regiões periapicais de mandíbulas humanas maceradas, e posteriormente as radiografias foram analisadas por sete observadores. Os autores concluíram que a qualidade das imagens digitais diretas é comparável à do filme Ektaspped na detecção de lesões ósseas periapicais.

Gröndahl, Ekestubbe e Gröndahl (1996a) citaram que não é necessária a tomada radiográfica durante o período compreendido entre a instalação dos implantes e a conexão dos pilares, a menos que ocorra o aparecimento de sinais e sintomas cuja origem não seja diagnosticada sem um exame radiográfico. As radiografias são indicadas quando da instalação da prótese para verificação da adaptação dos componentes da fixação, servindo as imagens base para futuras comparações em controle longitudinal. Os exames posteriores devem apresentar o nível ósseo marginal, estrutura óssea perimplantar e fraturas da fixação ou do parafuso do pilar que são raras. O exame radiográfico é especialmente importante aproximadamente um ano após a instalação da prótese, porque a maioria das alterações clínicas significantes ocorre durante o primeiro ano de função. As informações neste momento podem também ser usadas para identificar pacientes de grande risco de desenvolver complicações futuras.

Gröndahl, Ekestubbe e Gröndahl (1996b), citaram que a técnica radiográfica indicada para o controle dos implantes é a técnica intrabucal que possibilita a 
alteração da angulação relativa a cada fixação, sendo que quando a angulação é correta, podem ser vistas nitidamente as espiras em ambos os lados da fixação. Nos casos onde as espiras se apresentam precisas do lado esquerdo, mas borradas do lado direito deve-se repetir a radiografia, diminuindo a angulação vertical. Quando as espiras aparecem precisas do lado direito e difusas do lado esquerdo, nova tomada deve ser feita aumentando a angulação vertical do feixe de raios $X$, independente do arco em que os implantes estão posicionados inferior ou superior. $\mathrm{O}$ ajuste na angulação vertical será de aproximadamente 10ำ nos casos onde apenas as espiras de um dos lados da fixação estiverem difusas, e deverá ser corrigida em torno de $20^{\circ}$, quando as espiras estiverem borradas em ambos os lados.

Van der Stelt (1996) em trabalho intitulado: "Radiologia Digital com o Uso do Digora para Registros Técnicos" relatou que as melhorias na tecnologia digital tem trazido grande alteração na execução do radiodiagnóstico, com o registro e análise das imagens facilitados pelo computador. As vantagens do sistema digital Digora sobre os sistemas CCD, são as similaridades da placa de fósforo com o filme padrão no que diz respeito à forma fotográfica de registro de raios $\mathrm{X}$ e o fato de seu sensor não possuir fios conectados, o que permite uma maior liberdade de movimento em relação à localização dos equipamentos digitais e aparelhos de raios $\mathrm{X}$.

Jeffcoat et al. (1996) avaliaram a capacidade da técnica de subtração radiográfica digital para detectar e quantificar alterações conhecidas de massa óssea alveolar "in vivo" em 3 centros de estudos (Universidade de Washington, Universidade da Florida e Universidade do Alabama). Foram realizados 34 pares de radiografias interproximais em dezessete (17) pessoas usando chips de massa conhecida de 1, 7 e 10mg, para melhor simular a perda ou ganho de osso periodontal. O chip foi fixado ao filme e em cada região foram realizadas duas 
radiografias, sendo uma com o chip e a outra sem o chip. Se a primeira radiografia fosse realizada com o chip, o resultado da subtração radiográfica deveria apresentar perda óssea. E no caso da segunda radiografia ser realizada com o chip, o resultado da subtração radiográfica deveria apresentar ganho ósseo. Foram utilizados códigos para determinar qual exposição foi realizada com o chip. As radiografias foram posteriormente digitalizadas e a primeira radiografia foi subtraída da segunda após correção no contraste e discrepâncias geométricas através de software escrito na linguagem C. O método utilizado para avaliação da subtração permitia isolar a alteração óssea, superpor a área com alteração óssea na radiografia original para facilitar a interpretação da região com alteração e quantificar o tamanho da alteração em termos de massa. Os resultados mostraram que a mais baixa sensitividade no método ocorreu quando da utilização do chip de $1 \mathrm{mg}$ (uma falha em dois centros e duas falhas em um centro). As "lesões" com $7 \mathrm{mg}$ ou mais foram detectadas com sensitividade e especificidade de $100 \%$. Os autores concluíram que a subtração radiográfica digital é uma técnica válida para medir as alterações do osso alveolar.

A ausência de radiolucência perimplantar em radiografias tem sido utilizada com um critério para avaliar o sucesso de um implante. Com o propósito de avaliar a exatidão no diagnóstico das radiolucências perimplantares, Sewerin, Gotfredsen e Stoltze (1997) realizaram estudo “in vitro" em 20 mandíbulas humanas. Após preparo dos sítios ósseos para colocação de implantes Astra (Astra Tech A/S, Taastrup, Denmark) de $10 \mathrm{~mm}$ com diâmetro de $3,5 \mathrm{~mm}$ nas regiões do incisivo, pré-molar e molar e do posicionamento do implante em íntimo contato com o osso, foram realizadas radiografias à $90^{\circ}$ de angulação com o implante e a 105․ Posteriormente o implante foi removido (desparafusado) e realizado um defeito ósseo por meio de uma broca de $3,7 \mathrm{~mm}$ de diâmetro $(0,1 \mathrm{~mm}$ de espaço de cada lado). Novas 
radiografias foram obtidas após o reposicionamento do implante. Com uma broca de 3,85mm de diâmetro, novo defeito ósseo foi realizado e após a colocação do implante no osso $(0,175 \mathrm{~mm}$ de espaço $)$ foram executadas novas radiografias. A avaliação dos resultados por 10 examinadores mostrou baixa concordância interexaminadores. A especificidade encontrada foi marcadamente baixa e a sensibilidade moderada. Foi achada uma diferença significativa no diagnóstico exato para o espaço perimplantar de $0,175 \mathrm{~mm}$ quando comparado ao espaço de $0,1 \mathrm{~mm}$, sendo que o maior índice de acerto ocorreu para o espaço de $0,175 \mathrm{~mm}$. Os autores concluíram que a radiografia não parece ser um método adequado para o diagnóstico de espaço perimplantares, embora a exatidão no diagnóstico aumentou com o aumento da largura dos espaços, sendo que uma correta projeção ortorradial não aumentou a exatidão no diagnóstico.

Chilvarquer (1997) citou os critérios para a execução de procedimentos radiográficos estabelecidos por Strid (1985) para a avaliação da osteointegração. A técnica radiográfica utilizada deve ser a técnica do paralelismo de cone longo, com a distância área focalfilme de $40 \mathrm{~cm}$, realizada em aparelhos de raios $X$ com quilovoltagem marcando entre 65 e $70 \mathrm{kVp}$. A radiografia deve ser executada o mais ortorradial a cada implante, utilizando-se preferencialmente o filme infantil. A periodicidade segundo Strid (1985) citado pelo autor, deve ser após a colocação da prótese (aproximadamente 6 meses da cirurgia), após 6 meses e anualmente até o $3^{\circ}$ ano. Depois o exame deve ser feito a cada 3 anos. Chilvarquer (1997) lembra que - exame clínico é o principal critério para se afirmar com segurança a osteointegração, não sendo o exame radiográfico conclusivo quando da definição de osteointegração. 
Brägger (1998) fez uma revisão das informações recentes obtidas por meio de avaliações radiográficas em diversos estágios clínicos da vida do implante, ressaltando que o exame radiográfico dos tecidos perimplantares é essencial para o diagnóstico do sucesso, estabilidade, bem como das falhas do implante dental, além de ser usado em estudos do controle das alterações do osso perimplantar.

Brägger et al. (1998) realizaram um estudo em 20 voluntários saudáveis com o propósito de verificar in vivo os erros do método de subtração radiográfica, bem como o efeito dos parâmetros quando da obtenção de radiografias periapicais padronizadas para análise densitométrica por computador. Os pacientes foram orientados a não realizar controle de placa mecânico ou químico durante 21 dias. Inicialmente foi realizada uma radiografia periapical padronizada por meio de uma modificação no posicionador do sistema Rinn (usado com um bloco de mordida de acrílico) na região de pré-molar e ou molar (superior e inferior) e após 21 dias nova tomada radiográfica foi executada. As radiografias foram digitalizadas por meio de uma câmera branca e preta. As radiografias foram superpostas, alinhadas (o melhor possível) e corrigidas as diferenças de densidade e contraste e posteriormente subtraídas. A diferença nos níveis de cinza entre a radiografia inicial e a radiografia após 21 dias em um local sem mudanças na densidade, deveria mostrar um perfeito cancelamento das estruturas. Áreas com níveis de cinza menor que 128 (metade da escala digital de cinza dada pelo software utilizado) na subtração radiográfica apareceriam escuras, sendo indicativas de perda de densidade e as áreas com níveis de cinza maior que 128 apareceriam mais claras, indicando um aumento de densidade. Foram selecionadas áreas de interesse retangulares nos tecidos moles que recobriam as cristas ósseas interproximais e nas cristas ósseas. Para as áreas de interesse no osso, as alterações na densidade indicariam os erros da 
metodologia mais uma remodelação óssea superficial. Nas áreas de interesse em tecido mole, as alterações na densidade refletiriam os erros na metodologia mais a possibilidade de mudanças na densidade dos tecidos moles devido à gengivite experimental. Foram utilizados três parâmetros de correção de níveis de tons de cinza: 0 (sem correção); +5 tons de cinza e +10 tons de cinza. No parâmetro 0 (sem correção), todas as áreas de interesse mostraram alterações ra densidade. Quando da utilização do parâmetro $+5,44$ das 45 regiões de interesse em osso maxilar e 60 das 66 regiões de osso mandibular apresentaram alterações de densidade. Das regiões de interesse em tecido mole, 41 das 45 da maxila e 26 das 66 na mand íbula demonstraram alterações. Quando da utilização do parâmetro + 10, 16 regiões em osso maxilar e 12 em osso mandibular apresentaram alterações. Já nas regiões de interesse em tecido mole, 13 na maxila e 1 na mandíbula também apresentaram alterações. Os autores concluíram que a utilização de parâmetros pode evitar o diagnóstico de falso positivo.

Vale, Bramante e Bramante (1998) avaliaram o fator de distorção da placa óptica do sistema de imagem digital Digora na determinação do comprimento de sessenta dentes. Concluíram que não houve diferença estatisticamente significante entre as medidas real e digital nas três imagens Digora (padrão, negativa e 3D). Explicam que imagem padrão obtida no Digora é a imagem semelhante a radiografias convencionais com a vantagem de poder ajustar contraste e brilho da imagem. Imagem negativa é a conversão da imagem dental em um negativo pela mudança das estruturas radiolúcidas em radiopacas e vice-versa. Imagem 3D é o resultado da transformação da imagem dental em imagem tridimensional, na qual as imagens de alta densidade física aparecem em alto relevo. 
A subtração radiográfica digital tem sido considerada importante método não invasivo, para avaliar e quantificar as alterações na massa óssea alveolar ocorrida após terapia periodontal ou reabilitação com implantes. Loftin et al. (1998) realizaram um experimento controle para estimar as alterações na massa óssea através da subtração radiográfica de radiografias realizadas em mandíbulas secas com alterações na posição espacial de um chip ósseo com a massa variando de 1 a 35 mg. Foi construído um jig para fixar o filme na mandíbula para minimizar o "ruído" estrutural resultante da discrepância geométrica. Também foi fixada ao jig uma escala de alumínio para facilitar a análise quantitativa. Foram realizadas cinco radiografias com chips de diferentes massas, posicionados com o lado maior paralelo à face vestibular da mandíbula. Uma segunda série de 5 radiografias foi realizada utilizando os mesmos chips, com mesma localização espacial e projeção geométrica, mas cada chip foi reposicionado com o lado maior perpendicular à face vestibular da mandíbula. Obtiveram uma série de cinco radiografias controles que foram realizadas sem chip ou escala de alumínio para facilitar a subtração radiográfica digital. As radiografias foram digitalizadas através de uma câmera de vídeo (Panasonic 5100). As imagens foram subtraídas usando o software TACT (Verity Software, Winston-Salem, NC, USA) e minimizado o efeito das diferenças de contraste nos filmes devido a variações na exposição e processamento químico através da correção de Gamma descrita por Ruttimann, Webber e Schmidt (1986). A massa óssea estimada derivada dos dois chips com orientações diferentes foram comparadas usando o teste t-Student's e apresentaram diferenças estatisticamente significantes $(p<0.05)$. Os autores não conseguiram demonstrar uma correlação significante entre a massa do chip e o tamanho da discrepância entre as duas orientações para estimar as diferenças na massa relativa do chip ósseo. A 
correlação entre a massa real do chip e a massa estimada derivada da radiografia com orientação perpendicular foi maior $\left(r^{2}=0,945\right)$ que a massa estimada da imagem com orientação do lado maior do chip paralelo à face vestibular da mandíbula $\left(r^{2}=\right.$ 0.81). Concluem que não foi possível estimar com um alto grau de confiabilidade a massa dos chips ósseos e que a orientação do chip demonstrou produzir um efeito significante na estimativa de massa óssea. A orientação do chip que atenua ao máximo o feixe de raios $X$ resulta na melhor estimativa da massa óssea. Loftin et al. (1998) sugerem que estimar a massa óssea através dos dados da subtração radiográfica pode variar significativamente dependendo da orientação (forma) da lesão.

Chilvarquer e Chilvarquer (2000), avaliaram os métodos recentes por imagem e descreveram as diferenças e os conceitos das radiografias digitais diretas e indiretas e suas aplicações no controle e planejamento de implantes osteointegrados.

Inicialmente os implantes osseointegrados foram utilizados principalmente na região anterior da mandíbula, sendo que atualmente, o seu uso é comum na região posterior em ambos os arcos. Para avaliar o sucesso de implantes na região posterior da mandíbula, Bahat (2000) apresentou um estudo clínico em 660 implantes tipo Brånemark em 202 pacientes. Os pacientes foram reabilitados com próteses fixas de metalocerâmicas e proservados por 12 anos. O protocolo radiográfico foi realizado com radiografias periapicais obtidas pela técnica do paralelismo cone longo no ato cirúrgico, após a confecção da prótese e anualmente. As radiografias foram digitalizadas por meio de um scanner e mensurado o nível da crista óssea em milímetros utilizando o software NIH Image (Scion Corp, Bethesda, MD). Os resultados mostraram sucesso em 94,4\% entre 5 e 6 anos e 93,4\% após 10 
anos. Os dados obtidos sugeriram que alguns pacientes têm grande propensão a perder implantes. Entre os 30 pacientes que perderam implantes, 3 perderam 2 implantes, 1 perdeu 3 e 1 paciente perdeu 5 implantes. Nenhum destes 14 implantes perdidos foram devido à fratura. Estes 5 pacientes respondem por $36 \%$ do total de implantes perdidos. Os implantes com maior comprimento e diâmetro obtiveram resultados melhores do que os implantes menores e mais finos. A qualidade e quantidade de osso parecem ter pequena influência no sucesso no tratamento. A taxa de sucesso observada (95\% em 5 anos) apresentou-se como uma expectativa razoável para implantes osseointegrados localizados na região posterior da mandíbula.

Vedovato e Chilvarquer (2001) avaliaram os aspectos clínicos e radiográficos de implantes osteointegrados submetidos a carga de overdenture na mandíbula.

Hayek (2002) avaliou as alterações da densidade ótica do osso alveolar perimplantar em controle longitudinal, por meio de radiografias periapicais digitalizadas, de dezenove pacientes, os quais foram reabilitados com próteses totais inferiores tipo overdenture por meio de 2 implantes do tipo Brånemark. Foi realizada uma telerradiografia em norma lateral de cada paciente logo após a instalação da prótese sobre implantes, para a obtenção da inclinação dos implantes em relação ao plano de Frankfurt, para a posterior execução da técnica radiográfica intrabucal pelo paralelismo, com cone longo e com o feixe de raios $\mathrm{X}$ incidindo perpendicularmente ao longo eixo do implante. Os controles radiográficos foram realizados na instalação da prótese, após 6 meses e após 18 meses. As radiografias intrabucais padronizadas foram executadas com suporte porta-filmes (tipo Hanshin) e foram obtidas com os mesmos parâmetros na execução da técnica e de processamento, sendo então examinadas em um negatoscópio com luz de intensidade fixa e com o 
uso de máscara negra, comparando-as visualmente com o auxílio de uma lupa com aumento de 5 vezes, buscando assim a padronização da técnica. As radiografias que apresentaram diferenças na imagem das espiras do implante ou na densidade em relação à radiografia padrão (realizadas imediatamente após a instalação da prótese) foram repetidas e corrigidas segundo Gröndahl, Ekestubbe e Gröndahl (1996b). As referidas radiografias obtidas foram então capturadas por uma câmera de vídeo (preto e branco) por meio de um microscópio ótico (40x de aumento). Devido à ampliação utilizada, os implantes tiveram suas imagens digitalizadas em 2 etapas (metade direita e metade esquerda), sendo englobadas as três primeiras espiras do implante com margem de segurança. Estas imagens foram analisadas pelo software Imagelab versão 2000 desenvolvido pelo laboratório de informática dedicado à Odontologia (LIDO) da Faculdade de Odontologia da Universidade de São Paulo. Visando a padronização das áreas que foram mensuradas, o autor utilizou um gabarito personalizado, o qual foi sobreposto às imagens e analisadas as densidades óticas nas áreas de interesse (osso + implante), aonde eram esperadas alterações na densidade e nas áreas de controle (implante e osso), as quais não eram esperadas alterações. Nas áreas de controle foram realizadas regressões lineares e obtido um fator de correção da densidade, para compensar o efeito da falta de padronização da projeção geométrica e da densidade radiográfica. Os resultados mostraram que ocorreu variação percentual igual da densidade ótica na área de interesse em ambos os lados dos implantes analisados. Nos primeiros 6 meses e nos 18 meses após a instalação da prótese, a densidade ótica na área de interesse apresentou em média uma diminuição de aproximadamente 3 e $4 \%$ (respectivamente) enquanto que a variação percentual da densidade ótica na área de controle implante foi nula. A área de controle osso, demonstrou não ser 
adequada devido a sua grande variabilidade e pouca reprodutibilidade. $\mathrm{O}$ autor concluiu que as diferenças na densidade ótica da região de interesse (osso e implante) demonstraram aspecto compatível com o sucesso dos implantes osteointegrados, o que também é observado na literatura especializada.

\subsection{Implantes: função e / ou carga imediata}

Para a obtenção da osteointegração segundo Brånemark et al. (1977) era necessário aguardar um período de tempo após a instalação do implante no osso, para aplicar a carga oclusal protética. Este protocolo foi fundamentado em três pontos: reduzir o risco de infecção; impedir o crescimento da mucosa na direção apical do implante e minimizar o risco de cargas desfavoráveis e ou precoces sobre o implante, evitando a sua movimentação durante a fase inicial de reparo, o que resultaria em encapsulamento do implante por tecido fibroso. Baseando-se nos conceitos biológicos e tecnológicos da época, os autores recomendavam um período de reparo com ausência de cargas oclusais de três a quatro meses para implantes realizados na mandíbula e cinco a seis meses para a maxila.

Lekholm e Zarb (1985) classificaram a forma ou quantidade do processo alveolar residual em cinco grupos, dependendo do grau de reabsorção óssea após a extração dentária. Na forma ou quantidade tipo A, a maior parte do processo alveolar está presente; na forma tipo B ocorreu uma reabsorção moderada; na forma tipo C, ocorreu avançada reabsorção do processo alveolar e permaneceu somente osso basal; no tipo D já começou alguma reabsorção do osso basal; na forma tipo $E$, já 
aconteceu extrema reabsorção óssea. Em relação a qualidade óssea, os autores propuseram uma classificação em quatro tipos conforme suas características anatômicas. No tipo I, quase todo o osso é homogeneamente compacto; no tipo II uma camada de osso espessa e compacta circunda um núcleo de osso trabecular denso; no tipo III, uma fina camada de osso cortical circunda um núcleo de osso trabecular denso de resistência favorável e no tipo IV, uma fina camada de osso cortical circunda um núcleo de osso trabecular de baixa densidade.

Schnitman, Wohrle e Rubenstein (1990) realizaram estudos em mandíbulas edêntulas que foram reabilitadas com implantes, com o objetivo de avaliar 0 desempenho de implantes submetidos a função imediata. Foram realizados cinco a seis implantes em cada mandíbula, sendo que em apenas três foram instalados abutments e sobre estes, construída uma prótese total. Os outros implantes foram mantidos submersos, conforme o protocolo tradicional de dois tempos cirúrgicos. Os autores não encontraram diferenças estatisticamente significativas quando compararam os níveis de falhas dos implantes com função oclusal imediata, com os implantes sem carga, no mesmo paciente, durante um período de proservação de cinco anos.

De acordo com Brunsky (1992) os implantes dentais podem receber função oclusal precoce e/ou imediata, desde que os micromovimentos na superfície do implante não excedam $150 \mu \mathrm{m}$ durante a fase de osteointegração, evitando a formação de cápsula fibrosa. Os autores citam que a formação de tecido conjuntivo cicatricial na forma de cápsula fibrosa, anteriormente a adequada deposição e mineralização óssea, interfere no processo de osteointegração do implante, podendo levar ao insucesso do tratamento. 
Collaert e De Bruyn (1998) compararam a perda óssea ocorrida em implantes osseointegráveis tipo Brånemark realizados em um só estágio com o uso do procedimento clássico de dois estágios. Após um ano de função, os autores verificaram as mudanças radiográficas típicas de reabsorção óssea até a primeira espira mais coronária em ambas as modalidades.

Brånemark et al. (1999) apresentaram o protocolo The Brånemark Novum Protocol for the Same Day Teeth onde é descrita uma nova técnica de colocação de 3 implantes com carga imediata em um protocolo cirúrgico protético que permite a reabilitação do paciente através dos implantes e da prótese entre 6 e 8 horas após a cirurgia.

De acordo com Brånemark (2001) o principio do Novum foi concebido após anos de pesquisas, onde a preocupação era controlar a dinâmica espacial na interface entre o titânio e o osso e ao mesmo tempo verificar no entendimento da biologia dessa interface, assim como os efeitos dos procedimentos cirúrgicoprotéticos e forças funcionais na mandíbula.

Gottlow e Lundgren (2002) esclareceram a diferença entre a função oclusal imediata e a precoce em razão do tempo necessário para a instalação da prótese. A carga ou função oclusal imediata é aquela em que a prótese é instalada no mesmo dia da inserção dos implantes e a carga ou função oclusal precoce é aquela em que a prótese é instalada em até semanas após a inserção dos implantes.

Bogaerde et al. (2003) realizaram estudo com 124 implantes osteointegrados com função precoce em maxilas totais edêntulas e maxilas e mandíbulas posteriores parcialmente edêntulas. Enfatizaram a necessidade de obter uma alta estabilidade primária dos implantes e que as cargas oclusais devam ser controladas. Para o estudo realizado, os autores excluíram os pacientes com bruxismo e evitaram a 
confecção de próteses com extensões distais e usaram plataformas oclusais estreitas com cúspides rasas e contatos oclusais leves. As próteses parciais fixas foram conectadas em média uma semana após a instalação dos implantes, não excedendo 20 dias Após dezoito meses de controle, foram perdidos dois implantes, configurando uma taxa de sobrevivência de $96,4 \%$. Foi verificada uma perda óssea marginal em média de 1,6mm, sendo que a maior parte ocorreu nos primeiros seis meses, permanecendo estável após dezoito meses. Bogaerde et al. (2003) concluíram que a função precoce é viável e que os resultados obtidos são comparáveis aos dos protocolos convencionais de dois estágios.

Calandriello, Tomatis e Rangert (2003) analisaram o efeito da carga imediata no tratamento do edentulismo total, parcial e ou unitário tanto na maxila como na mandíbula posteriores, com a finalidade de avaliar se a estabilidade primária aumentada dos implantes seria um fator determinante para o sucesso da função imediata. Os autores descreveram uma técnica cirúrgica de sub preparação do leito receptor para as diferentes qualidades ósseas da mandíbula e da maxila. A oclusão das próteses foi realizada com contatos cêntricos leves e desoclusão lateral. Foram instalados cinqüenta implantes, sendo que transcorrido um a dois anos, apenas um implante localizado na maxila falhou. Foi observada uma perda óssea em média de 1,22mm após um ano. Calandriello, Tomatis e Rangert (2003) concluíram que a estabilidade primária aumentada dos implantes e uma oclusão leve resultaram em um alto índice de sucesso.

Rocci, Martignoni e Gottlow (2003) estudaram o efeito da carga imediata em cento e vinte um implantes instalados em mandíbulas posteriores, sendo sessenta e seis implantes com superfícies rugosas e cinqüenta e cinco com superfícies torneadas. Os resultados demonstraram após um ano, uma taxa de sucesso de 
$85,5 \%$ para os implantes torneados e $95,5 \%$ para os implantes com superfície rugosa. A remodelação óssea marginal verificada foi de $0,9 \mathrm{~mm}$ para o grupo de implantes com superfície rugosa e de $1,0 \mathrm{~mm}$ para o grupo de implantes torneados. Nos implantes torneados o número de implantes fracassados foi significativamente maior em tabagistas e em implantes realizados em sítios ósseos do tipo IV, segundo a classificação de Lekholm e Zarb (1985).

Constantino (2004) realizou estudo clínico em trinta e cinco pacientes os quais receberam noventa e oito implantes cônicos $\left(\right.$ Intra-Lock $^{\circledR}$ System ${ }^{\circledR}$ ) na maxila (46 implantes) e mandíbula (52 implantes) em regiões de osso tipo I, II e III, segundo a classificação de Lekholm e Zarb (1985), fazendo uso da osteocompressão (sob o torque de $80 \mathrm{~N} / \mathrm{cm}$ ), com o objetivo de otimizar a estabilidade primária dos implantes. Para verificar a resposta óssea sem a interferência de cargas oclusais, todos os implantes do grupo de estudo foram mantidos inativados durante o período de três meses. Foram realizadas radiografias periapicais no pós-operatório imediato e após trinta e noventa dias, além de exames clínicos. Os resultados demonstraram que do total de noventa e cinco implantes proservados (um paciente com três implantes interrompeu a proservação), quatro apresentaram mobilidade e foram removidos, sendo que três implantes demonstraram sinais radiográficos de perda na crista óssea alveolar marginal próxima de $3 \mathrm{~mm}$ em pelo menos uma face e um implante não foi detectada alteração radiográfica. O autor ressalta que não houve qualquer indício clínico ou radiográfico de necrose óssea decorrente da compressão exercida na instalação dos implantes (torque de $80 \mathrm{~N} / \mathrm{cm}$ ), atingindo $95,8 \%$ de osteointegração na amostra estudada.

Francischone (2004) destacou a importância da estabilidade primária e secundária do implante, fundamentais na determinação dos critérios para a carga 
imediata. A primária, que é a mecânica, é definitiva para se conseguir indicar uma carga imediata. Relacionada ao ato cirúrgico, depende da geometria do implante, da técnica cirúrgica e também da densidade óssea. Por outro lado, a estabilidade secundária é um complemento da mecânica. Tem aspectos biológicos relacionados às respostas dos tecidos na cirurgia e ao implante, além do próprio processo de cicatrização óssea. Cita a questão da nomenclatura mais adequada: carga ou função imediata? O autor considera que carga é alguma coisa estática e o que se tem na boca é algo dinâmico.

Tortamano Neto, Camargo e Veiga (2004) realizaram estudos em oito pacientes com ausências de dentes posteriores inferiores em um ou ambos os lados e que receberam dois implantes do sistema ITI (com 10mm de comprimento), com o objetivo de estabelecer critérios clínicos de qualidade óssea e estabilidade inicial dos implantes osteointegrados e para determinar quando estes poderiam ser receber cargas oclusais após a instalação dos mesmos. A estabilidade inicial dos implantes foi verificada imediatamente após a cirurgia por meio da utilização do Periotest ${ }^{\circledR}$. As próteses foram instaladas após dois dias da cirurgia e removidas após seis, oito, dez e doze semanas para a avaliação da mobilidade realizada pelo Periotest ${ }^{\circledR}$ e para a realização e comparação de radiografias periapicais padronizadas em relação a perda óssea marginal. Foram relacionadas aos fatores mobilidade, perda óssea e tipo de osso, às taxas de sucesso obtidas com o tratamento. Os resultados mostraram que implantes instalados em osso tipo II ou III, segundo a classificação de Lekholm e Zarb (1985), tendo valores de estabilidade inicial abaixo de zero (medidos com o Periotest $^{\circledR}$ ), podem ser carregados imediatamente após a cirurgia e alcançar sucesso clínico. Os autores concluíram que dois implantes de bom comprimento unidos entre si, são suficientes para se obter a estabilidade de 
implantes com carregamento imediato e que o Periotest ${ }^{\circledR}$ é uma ferramenta útil para analisar a estabilidade inicial dos implantes.

Lenharo e Cosso (2004) descreveram uma técnica de instalação imediata de implantes, restabelecendo ausências unitárias, com um protocolo cirúrgico e protético feito em um período de 2 horas. As modificações relativas ao diâmetro dos implantes, técnica cirúrgica, comprimentos maiores e biossegurança são fatores que alteram o potencial de qualidade da osteointegração. Os autores citam que a biomecânica relacionada com o desenho das próteses está associada diretamente com médias de sucesso e insucesso. Concluem que a prótese sobre implantes com carga imediata requer uma seleção cuidadosa dos implantes para se alcançar a estabilidade primária.

Nary Filho et al. (2004) publicaram um caso clínico no qual foi utilizado o sistema IOL (3I Implant Innovations Inc., Florida EUA) para a confecção de prótese total fixa provisória implanto-suportada, com o objetivo de apresentar uma alternativa de tratamento reabilitador com carga imediata. Segundo os autores, o sistema proporciona vantagens como baixo custo, praticidade técnica e reduzido tempo clínico, contudo entende-se o método como provisório, necessitando após o período de osteointegração, a realização de uma nova prótese, respeitando os protocolos técnicos convencionais que determinam a esplintagem rígida dos implantes, por meio de uma infra-estrutura metálica.

Oliveira et al. (2004) apresentaram um caso clínico de um novo sistema de implantes (XiVE ${ }^{\circledR}$, Dentsply Friadent, Mannheim, Alemanha) desenvolvido para o protocolo de carga imediata e fizeram uma análise da literatura em relação aos critérios para a sua utilização. O principio básico para a instalação de implantes em um estágio é a minimização de cargas excessivas, a fim de controlar a 
micromovimentação dos implantes durante a fase cicatricial. Foram ressaltadas a quantidade e qualidade do tecido ósseo; as propriedades macroscópicas dos implantes (tratamento de superfície); a estabilização bicortical e a distribuição dos implantes.

Viegas et al. (2004) realizaram breve revisão de literatura acerca da literatura acerca da aplicação da carga imediata sobre implantes e relataram um caso clínico com três implantes $\left(\right.$ Ankylos $\left.^{\circledR}\right)$ que receberam carga imediata e foram colocados na região posterior de maxila. Logo após a cirurgia foi instalada uma prótese provisória em resina acrílica unindo os implantes. Foi realizado exame radiográfico periapical aos três meses, o qual não demonstrou alterações significativas no tecido perimplantar e novo controle radiográfico aos trinta meses, sendo então observada uma pequena reabsorção óssea na região mesial do implante, a qual não consideraram significativa. Os autores concluíram que para maior previsibilidade na reabilitação por meio de próteses parciais sobre implantes com carga imediata devese selecionar adequadamente o caso, verificando estabilidade primária das fixações, oclusão, número e localização dos implantes, qualidade e quantidade óssea, dentes antagonistas e as expectativas do paciente em relação ao tratamento.

Souza Pinto (2004) realizou estudo clínico e radiográfico em treze pacientes que apresentavam edentulismo mandibular parcial posterior uni ou bilateral e que foram tratados com implantes osseointegráveis e função oclusal precoce. Foram instalados cinqüenta e dois implantes (trinta e nove implantes do tipo MKIII e 13 do tipo MKIV, ambos com superfície lisa) e estabelecida a função oclusal precoce com próteses parciais fixas aparafusadas, as quais foram instaladas em um período médio de sete dias, com variação de cinco a vinte e sete dias. Com objetivo de maximizar a estabilidade primária dos implantes, foi utilizada uma técnica cirúrgica 
adequada por meio de sub-preparação do leito receptor. Como protocolo protético foram executados ajustes oclusais nas próteses, mantendo a oclusão de relação central e sem contatos nos movimentos mandibulares protrusivos e de lateralidade. O protocolo radiográfico foi realizado com radiografias periapicais padronizadas por meio de posicionador XCP (Rinn Corporation Dentsply International-USA) associado a um bloco de mordida e executadas no dia da instalação da prótese, mensalmente até seis meses e após um ano. As radiografias periapicais foram digitalizadas por meio de scanner de mesa e analisadas no programa Computed Dental Radiography versão 2.6 (Schick Technologies, USA). A análise consistia na identificação de pontos nas faces mesiais e distais dos implantes e no nível ósseo, para posterior mensuração das alterações óssea lineares marginais. Entre os cinqüenta e dois implantes instalados, apenas um não obteve osteointegração durante o período de observação. O implante fracassado (tipo MKIV) foi instalado em uma mandíbula de qualidade óssea tipo IV segundo a classificação de Lekholm e Zarb (1985) e no decorrer do quarto mês de observação, o paciente apresentou desconforto persistente a mastigação, sem no entanto apresentar sinal radiográfico de perda óssea. Os resultados obtidos demonstraram em média uma perda óssea marginal aos seis meses de $1,04 \mathrm{~mm}$ e aos doze meses $1,07 \mathrm{~mm}$ não sendo influenciada pela qualidade óssea verificada na amostra estudada (tipo II; III e IV). Os dados, segundo o autor, sugerem que a possibilidade de sucesso do tratamento pela técnica da função oclusal precoce na mandíbula posterior, tem como pontos fundamentais: o grau de estabilidade primária do implante; sua posição no arco; a união dos implantes por meio de uma estrutura rígida que impeça a micromovimentação e a qualidade e quantidade óssea. Souza Pinto (2004) cita a necessidade de ajustes 
oclusais freqüentes no primeiro após a instalação das próteses com função oclusal precoce, até que a estabilidade dos contatos oclusais seja obtida.

Vasconcelos (2004) avaliou a função oclusal imediata em implantes instalados em maxilas desdentadas totais, no momento da cirurgia e após seis e 12 meses de função. Para tanto foi utilizada uma técnica cirúrgica modificada (com implantes instalados inclinados e com o uso da osteocompressão) e a avaliação da estabilidade dos implantes foi feita por meio da análise da freqüência de ressonância. Foram selecionados 10 pacientes, nos quais foram instalados 6 implantes na maxila com a submissão imediata dos mesmos à função oclusal imediata mediante a instalação de uma prótese fixa, com infra-estrutura metálica, 24 horas após a cirurgia. Estes pacientes foram acompanhados por um período de 12 meses em controles clínicos e radiográficos (radiografias panorâmicas e periapicais). As medidas da estabilidade do implante foram realizadas no momento da instalação dos implantes e após 6 e 12 meses. Após o período de acompanhamento, o autor obteve índices de sucesso de 95\% para os implantes e 90\% para as próteses. Dos sessenta implantes realizados, Vasconcelos (2004) não obteve sucesso em três implantes que foram removidos. Em relação aos valores da estabilidade dos implantes foi utilizado o aparelho OSSTELL ${ }^{\mathrm{TM}}$ (modelo 6.0 software versão 060, Integration Diagnostics, Suécia), sendo observada uma diferença estatisticamente significativa entre os valores iniciais e após 6 e 12 meses. Não houve diferença estatisticamente significativa entre os valores da estabilidade obtidos entre os períodos de 6 e 12 meses. Vasconcelos (2004) salienta que, embora a maxila (na região posterior aos pré-molares) tenha predominância de osso tipo III segundo a classificação de Lekholm e Zarb (1985), a utilização de implantes longos, instalados de forma inclinada, na posição distal bilateral, associada à técnica da 
osteocompressão, garantiu a estabilidade inicial destes implantes e que a união dos implantes por meio de uma infra-estrutura metálica rígida, a qual impediu a micromovimentação acima dos limites biologicamente aceitáveis, constituíram-se em fatores que contribuíram para o índice de sucesso alcançado. O autor conclui que a submissão dos implantes instalados na maxila, por intermédio da técnica cirúrgica modificada, à função oclusal imediata é um procedimento com alta previsibilidade, desde que bem selecionado e executado e que a análise da freqüência de ressonância é um método eficiente para a avaliação da estabilidade inicial e tardia dos implantes.

Vasconcelos et al. (2005) propuseram um novo protocolo para reabilitação de pacientes com edentulismo total na mandíbula, com a finalidade de simplificar os procedimentos cirúrgicos e protéticos e reduzir os custos do tratamento. Os autores citam que o edentulismo pode debilitar o paciente tanto funcional quanto esteticamente, sendo que após a perda dentária, se inicia um processo contínuo de reabsorção óssea que pode ser acelerado pelo uso da prótese total. 


\section{PROPOSIÇÃO}

A proposta neste trabalho é avaliar longitudinalmente a densidade ótica do osso alveolar perimplantar na região cervical em pacientes previamente reabilitados com implantes osteointegrados com função imediata realizados em maxila por meio de radiografias periapicais cone longo analisadas digitalmente pelo software Imagelab. 


\section{CASUÍSTICA-MATERIAL E MÉTODOS}

\subsection{Casuística-Material}

Foram selecionados para o estudo dez pacientes, sendo sete do sexo feminino e três do sexo masculino, com faixa etária variando de 35 a 75 anos, os quais receberam reabilitações por meio de próteses apoiadas em seis implantes osteointegrados com função imediata (tipo Brånemark) na maxila.

Os dez pacientes foram selecionados pela necessidade de instalação de implantes na maxila para reabilitação protética e por apresentarem boa saúde geral.

Esta pesquisa teve aquiescência do Comitê de Ética em Pesquisa da Faculdade de Odontologia da Universidade de São Paulo - protocolo 168/04 (Anexo A). 


\subsection{Métodos}

4.2.1 realização dos implantes

O Brånemark Osseointegration Center - São Paulo sob supervisão do Prof. Dr. Laércio W. Vasconcelos, realizou reabilitações por meio de próteses apoiadas em implantes osteointegrados com função imediata (tipo Brånemark) na maxila nos dez pacientes utilizados neste estudo.

Os pacientes foram submetidos a exames clínicos, laboratoriais, avaliação cardiológica com eletrocardiograma e radiografias panorâmicas e tomografias no pré-operatório.

Quanto às condições prévias da maxila, cinco pacientes eram desdentados totais e quatro possuíam dentes que foram submetidos à extração no mesmo ato cirúrgico da instalação dos implantes e um paciente apresentava um implante do tipo justa-ósseo que foi removido no mesmo ato cirúrgico da instalação dos implantes.

Para a execução deste estudo foram utilizados implantes Standard de superfície lisa e hexágono externo Nobel Biocare (Nobel Biocare, Gothenburg, Suécia) com diâmetro de $3,75 \mathrm{~mm}$ ou $4 \mathrm{~mm}$ e comprimentos de $13 \mathrm{~mm}, 15 \mathrm{~mm}, 18 \mathrm{~mm}$, e $20 \mathrm{~mm}$.

Os implantes foram instalados em regiões com diferentes qualidades ósseas, que foram identificadas pela experiência do cirurgião durante a preparação e inserção do implante.

Para a obtenção da maior estabilidade primária possível, os implantes distais foram instalados com inclinação no sentido distal para mesial, procurando estabilizá- 
los em osso de maior densidade (região entre os pré-molares). A técnica cirúrgica também foi direcionada para a obtenção de estabilidade na cortical da parede anterior do seio maxilar e na cortical da fossa nasal.

A avaliação da estabilidade do implante foi realizada pela análise da freqüência de ressonância obtida por meio do aparelho OSSTELL ${ }^{\mathrm{TM}}$ (modelo 6.0, programa versão 1060, Integration Diagnostics, Suécia). Um coeficiente de estabilidade alto corresponde à uma estabilidade alta.

Todas as próteses fixas foram instaladas em até 24 horas após a cirurgia.

Após sete dias da instalação foram verificadas novamente a oclusão e os contatos prematuros nas posições de relação cêntrica e máxima intercuspidação funcional, movimentos de lateralidade e protrusão, fazendo-se os ajustes oclusais necessários.

Os pacientes após a instalação das próteses fixas foram acompanhados em controles clínicos e radiográficos. Os períodos de controle considerados para o estudo bram imediatamente após a instalação das próteses, após seis meses e doze meses. Nestes períodos procedeu-se a avaliação clinica, radiográfica e mediuse novamente a estabilidade dos implantes com o aparelho OSSTELL ${ }^{\mathrm{TM}}$.

\subsection{2 a valiação radiográfica da amostra}

O controle radiográfico foi realizado por meio de radiografias panorâmicas e radiografias periapicais obtidas imediatamente após a instalação das próteses, após seis meses e doze meses. 
A amostra inicial era de sessenta implantes, sendo que durante a avaliação da ressonância três implantes não apresentaram medidas compatíveis com os valores de estabilidade primária e foram removidos. Posteriormente devido a problemas de padronização geométrica, foram eliminados nove implantes, tal fato occorreu devido à excessiva inclinação cirúgica dos implantes distais.

A radiografia panorâmica foi executada no aparelho Orthopantomograph OP 100 (Instrumentarium Corp. Imaging Division, Tuusula, Finlândia) e teve como finalidade observar o posicionamento dos implantes e a sua relação com as estruturas anatômicas vizinhas (Figura 4.1).

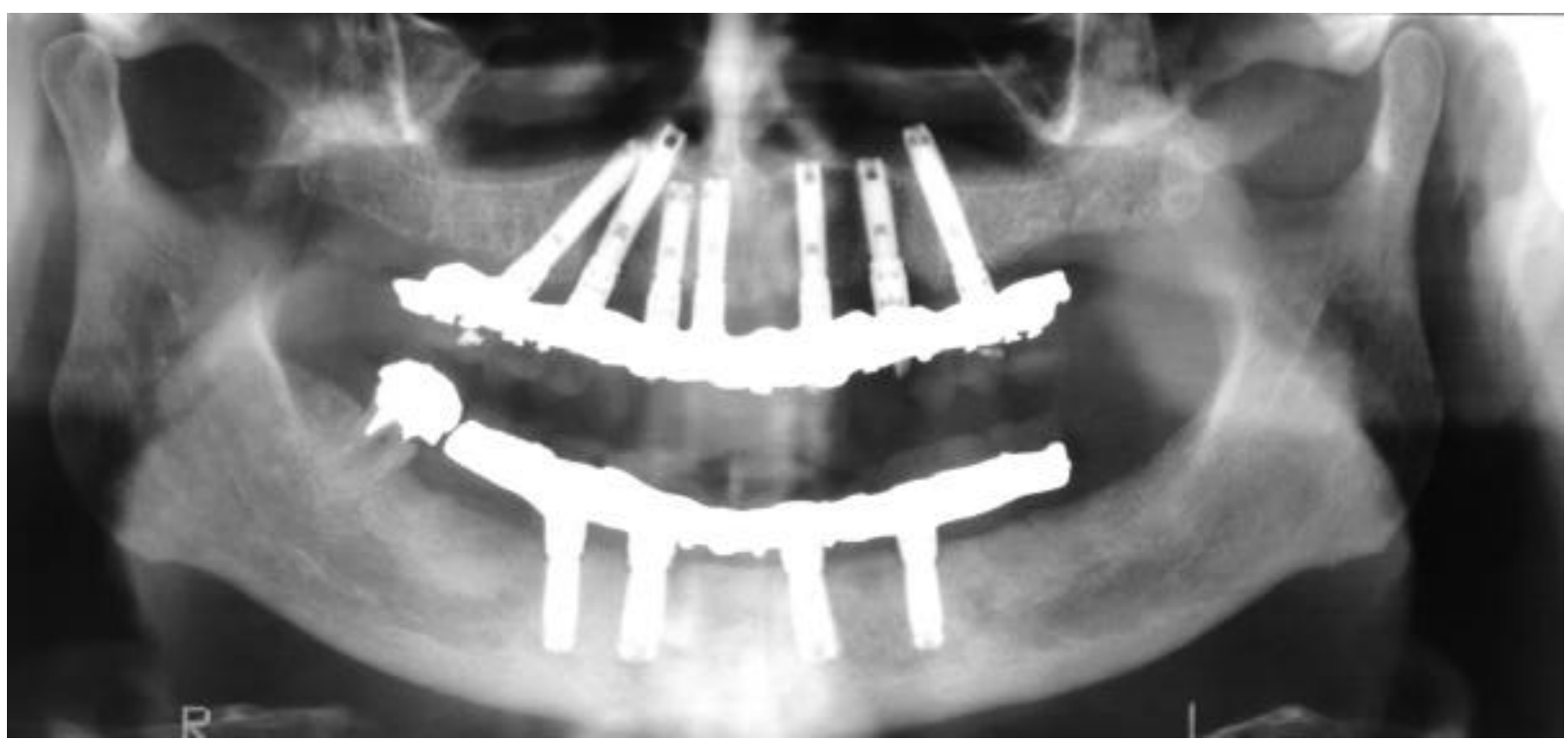

Figura 4.1 - Radiografia panorâmica após a instalação dos implantes

As radiografias periapicais foram obtidas pela técnica do paralelismo cone longo, com suporte para a região anterior do tipo Hanshin (Hanshin Technical Laboratory, Ltdinishinomiya, Japão), utilizando filme Ultraspeed (Eastman Kodak Company, Rochester, N.Y., USA), tamanho 1.2 (padrão), com o aparelho de raios X Yoshida X - 70s (Yoshida Dental MFG Co. Ltd, Tokyo, Japão) em regime de trabalho de $70 \mathrm{kVp}, 10 \mathrm{~mA}$ e tempo de exposição de $0.55 \mathrm{~s}$. 
Foi realizada uma radiografia periapical para cada implante, imediatamente após a instalação da prótese e nos controles realizados aos 6 e 12 meses. Para a correta execução da técnica periapical, utilizou-se como orientação para o ângulo horizontal a conexão do implante (a qual era visível clinicamente), sendo que a incidência dos raios $X$ foi perpendicular à mesma (zero de angulação horizontal em relação ao implante).

Em relação ao ângulo vertical, a radiografia periapical foi executada procurando posicionar o conjunto posicionador-filme o mais paralelo possível à inserção do implante, com o objetivo de obter um ângulo vertical perpendicular ao implante. Quando necessário, foi realizada a correção do ângulo vertical, baseandose no trabalho de Gröndahl, Ekestubbe e Gröndahl (1996b), o qual faz referência à alteração da angulação vertical relativa a cada fixação, demonstrando que quando a angulação é correta, podem ser vistas nitidamente as espiras em ambos os lados da fixação.

Nos casos onde as espiras se apresentavam precisas do lado esquerdo, mas borradas do lado direito, repetiu-se a radiografia, diminuindo a angulação vertical. Quando as espiras apareciam precisas do lado direito e difusas do lado esquerdo, nova tomada realizou-se, aumentando a angulação vertical do feixe de raios $X$. $O$ ajuste na angulação vertical foi de aproximadamente $10^{\circ}$ nos casos onde apenas as espiras de um dos lados da fixação estavam difusas, e em torno de $20^{\circ}$, quando as espiras estavam borradas em ambos os lados.

O processamento dos filmes foi realizado em processadora automática modelo Level 360 (J. Morita Corporation, Osaka, Japão), regulada a um tempo fixo de 4,5 min e foi utilizando soluções processadoras da marca Kodak. 
As radiografias periapicais foram realizadas procurando-se obter uma incidência ortorradial mais precisa em relação aos implantes (Figuras 4.2a, b e c).

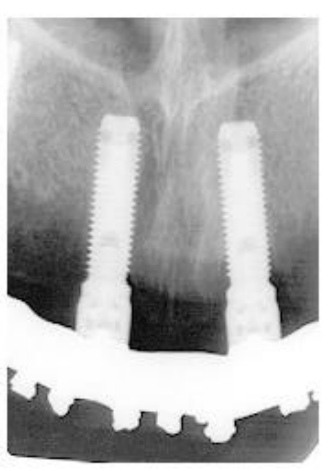

a) imediatamente após

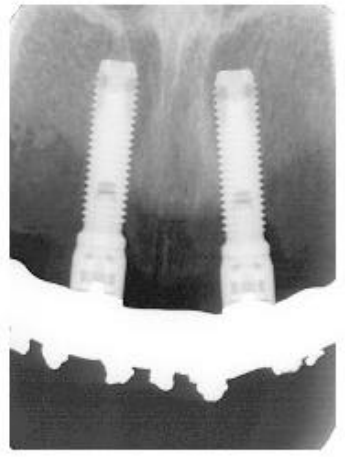

b) 6 meses após

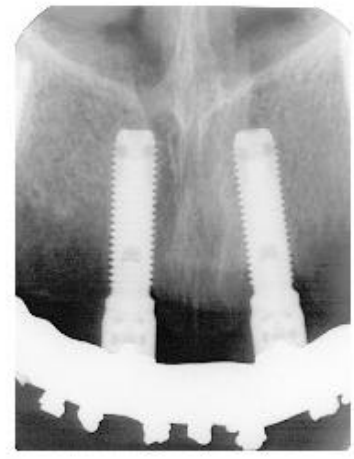

c) 12 meses após

Figura 4.2 - Radiografias periapicais padronizadas realizadas após a instalação da prótese

Posteriormente foi realizada a captura das imagens realizadas por meio de uma câmera de vídeo JVC TK-870U acoplada a um microscópio ótico Laborlux -S, utilizando ampliação de 40 vezes, possibilitando assim uma interpretação mais precisa da interface osso implante (Figura 4.3).

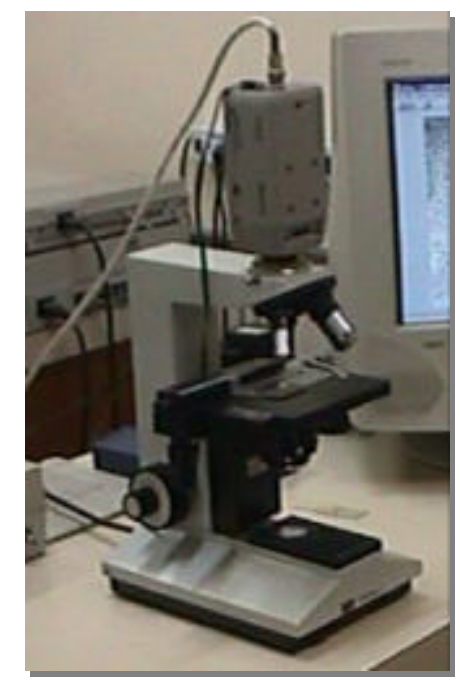

Figura 4.3 - Câmera de vídeo acoplada ao microscópio ótico 
Devido à ampliação utilizada, a captura da imagem de cada implante foi realizada em duas etapas, sendo primeiro na metade direita e na seqüência na metade esquerda do implante, envolvendo as três primeiras espiras do implante com uma margem de segurança (Figuras 4.4a e b).

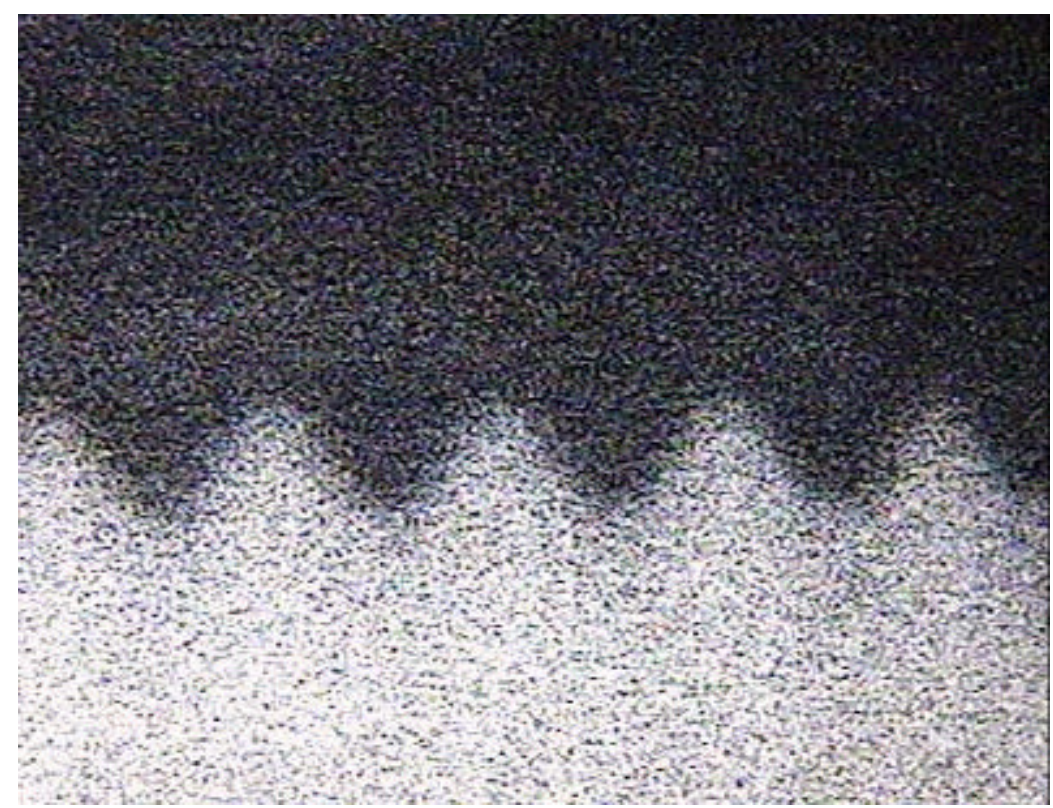

a) Metade direita do implante

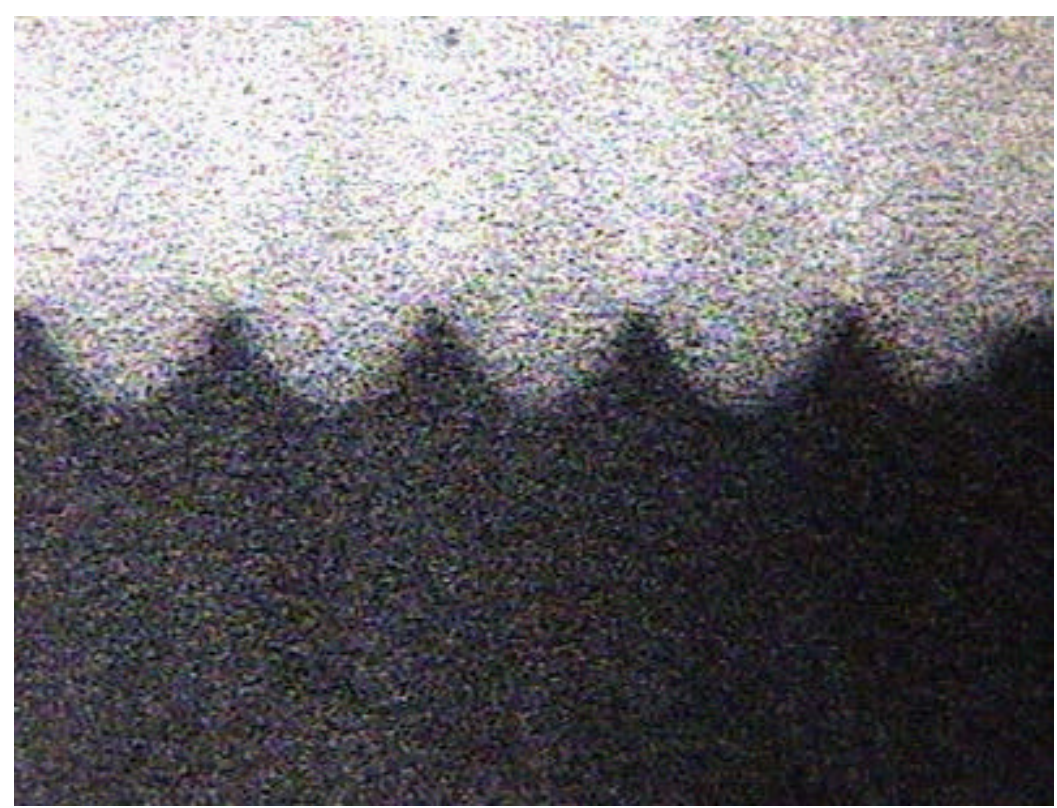

b) Metade esquerda do implante

Figura 4.4 - Captura da imagem radiográfica do implante realizada em duas etapas 
As imagens foram processadas em um microcomputador Pentium III Intel, 256 Mega bites de RAM, com monitor SVGA 17" e analisadas utilizando-se o programa Imagelab versão 2000 desenvolvido pelo laboratório de informática dedicado à Odontologia (LIDO) da Faculdade de Odontologia da Universidade de São Paulo.

Visando obter a padronização das áreas a serem posteriormente mensuradas, foi projetado um gabarito utilizando o programa de imagens gráficas Adobe Photoshop 5.0.

O programa ImageLab possibilita a sobreposição de imagens, a seleção de áreas e mensuração da densidade ótica (Figura 4.5).

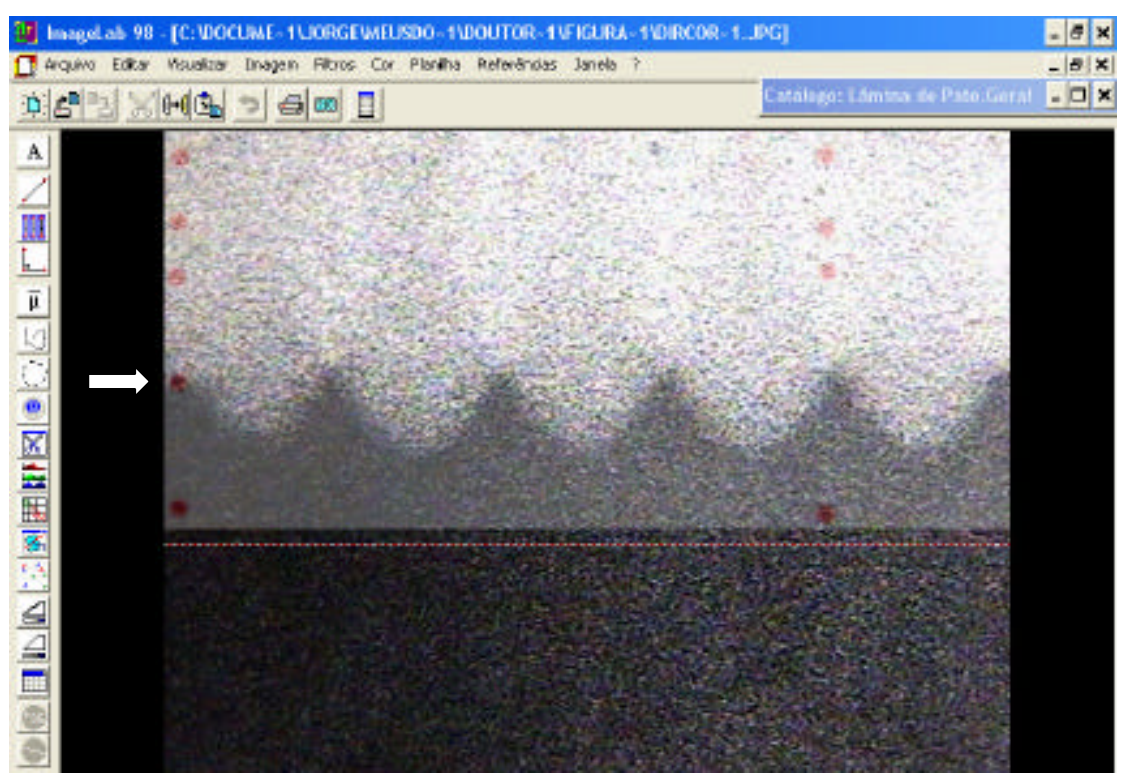

Figura 4.5 - Sobreposição do gabarito

O gabarito utilizado foi formado por dois polígonos de quatro lados cada, com marcações apenas por meio de pontos de referência localizados nos respectivos vértices, sendo que no maior polígono (a ser sobreposto na área de interesse) havia uma marcação de referência de forma a garantir a padronização das áreas quando da sobreposição das imagens, localizado no ponto de união da espira cervical com o implante (Figura 4.5). Após a sobreposição do gabarito sobre a imagem da 
radiografia, foram selecionadas as áreas por meio da ligação entre os pontos de cada polígono utilizando uma ferramenta disponível no programa (Figura 4.6).

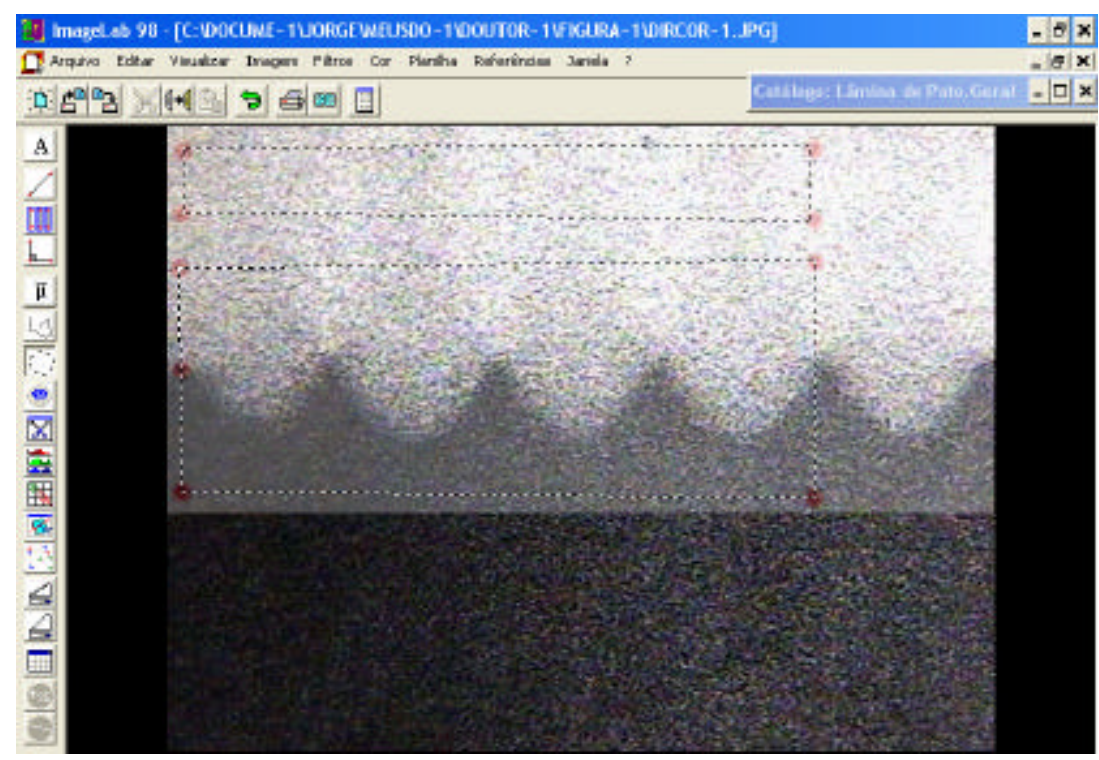

Figura 4.6 - União dos pontos do polígono

A sobreposição do gabarito à imagem a ser estudada foi realizada utilizando $25 \%$ de transparência do gabarito de forma a permitir a observação da área a ser mensurada.

Foram consideradas para o estudo a existência da variabilidade da projeção geométrica e a variabilidade na densidade. Para a correção da variabilidade apresentada pelo método, foi utilizado como controle a área do implante, baseada em metodologia utilizada em estudo pregresso (HAYEK, 2002).

O posicionamento dos polígonos que compunham o gabarito foi realizado de forma a abranger a área de interesse osso + implante (OI) e a área de controle implante (I), da imagem da metade direita e esquerda de cada implante (Figura 4.7). 


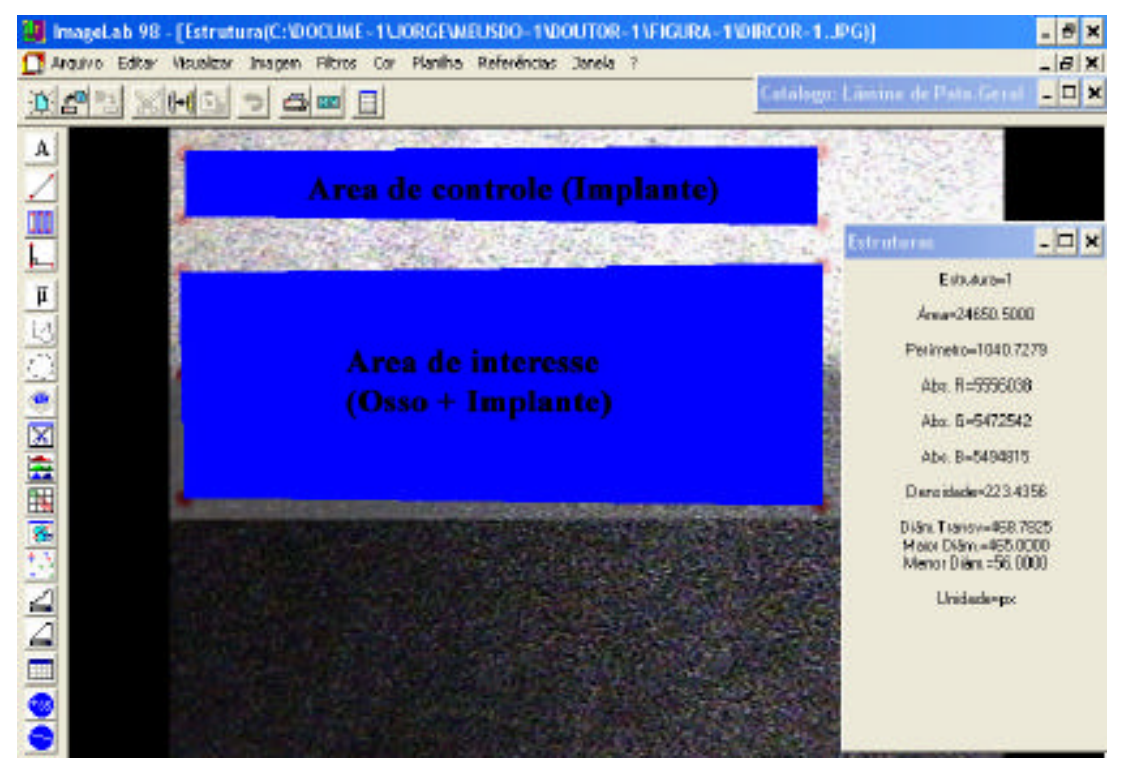

Figura 4.7 - Seleção das áreas de controle e de interesse

Imediatamente após a seleção das áreas, foram obtidas as mensurações de densidade ótica de cada área. A densidade ótica representa a quantidade de luz absorvida por unidade de área. O cálculo para obtenção da densidade ótica é realizado dividindo-se a absorção total de luz pela área estudada.

As medidas foram obtidas nas imagens capturadas das radiografias realizadas imediatamente após a instalação da prótese (T1), após 6 meses (T2) e 12 meses (T3), seguindo os parâmetros acima descritos.

Um radiologista treinado no procedimento de avaliação das radiografias no pós-operatório de implantes e na correção das espiras, realizou o controle de qualidade, examinando as radiografias periapicais dos dez pacientes em um negatoscópio com luz de intensidade fixa e com o uso de máscara negra, comparando-as visualmente com o auxílio de uma lupa com aumento de cinco vezes, realizando uma pré-seleção empírica da amostra.

Foram excluídas da amostra as radiografias que apresentaram diferenças visualmente significativas na avaliação da qualidade da imagem das espiras do implante ou na densidade em relação à radiografia padrão (realizadas imediatamente após a instalação da prótese). 


\subsection{3 análise exploratória dados}

Após a obtenção das medidas de densidade ótica procedeu-se na análise exploratória de dados, visando identificar se haviam discrepâncias nas medidas de densidade ótica das amostras.

Utilizou-se a metodologia proposta por Botter (2002) para retirada de dados discrepantes, conforme etapas descritas a seguir:

- Ordenação dos dados: verificou-se a presença de lacunas nos dados, duplicações e visualização de dados discrepantes, usando o programa Excel 2000;

Avaliação descritiva: elaborou-se estatística descritiva, utilizando programa de análise de dados Minitab 14;

Visualização dos dados: utilizourse histogramas, gráfico de freqüência acumulada e diagrama de dispersão para identificar o comportamento da amostra;

Agrupamento e limpeza dos dados: utilizou-se a metodologia de gráfico de caixas ou denominado "BoxPlot", disponível no programa Minitab 14 para identificar dados discrepantes com um nível de confiança estabelecido. 
Após a realização da análise descrita acima, obteve-se uma amostra consistente para a avaliação do experimento.

Para indicar as medidas utilizourse as seguintes nomenclaturas:

T1: período T1

T2: período T2

T3: período T3

I: área de controle implante

Ol: área de interesse osso + implante

D: Lado Direito

E: Lado Esquerdo

DI: lado direito da área de controle implante

El: lado esquerdo da área de controle implante

DOI: lado direito da área de interesse osso+implante

EOI: lado esquerdo da área de interesse osso+implante

Considerando a temporalidade, obteve-se as medidas com as seguintes nomenclaturas:

- T1DI - Densidade ótica no período 1 da área de controle implante na metade direita;

- T2DI - Densidade ótica no período 2 da área de controle implante na metade direita;

- T3DI - Densidade ótica no período 3 da área de controle implante na metade direita; 
- T1DOI - Densidade ótica no período 1 da área de interesse osso + implante da metade direita;

- T2DOI - Densidade ótica no período 2 da área de interesse osso + implante da metade direita;

- T3DOI - Densidade ótica no período 3 da área de interesse osso + implante da metade direita;

- T1El - Densidade ótica no período 1 da área de controle implante na metade esquerda;

- T2EI - Densidade ótica no período 2 da área de controle implante na metade esquerda;

- T3EI - Densidade ótica no período 3 da área de controle implante na metade esquerda;

- T1EOI - Densidade ótica no período 1 da área de interesse osso + implante da metade esquerda;

- T2EOI - Densidade ótica no período 2 da área de interesse osso + implante da metade esquerda;

- T3EOI - Densidade ótica no período 3 da área de interesse osso + implante da metade esquerda.

\subsubsection{2 correção das distorções de procedimentos}

Considerou-se que a densidade ótica da área de controle implante deveria permanecer inalterada ao longo do tempo, entretanto visando corrigir possíveis 
distorções de procedimentos, utilizou-se as medidas de variação percentual da densidade da área de controle implante de cada período em relação à média das densidades da área de controle implante nos três períodos, como referência para corrigir a densidade da área de interesse osso + implante.

As equações a seguir demonstram a correção das medidas realizadas em função da variação percentual da densidade da área de controle implante.

Inicialmente obteve-se a média das densidades óticas da área de controle implante ao longo dos períodos para cada lado conforme equação 4.1:

Média DI: T1DI + T2DI + T3DI / 3

Média EI: T1EI + T2EI + T3EI / 3

Equação 4.1: Média das densidades óticas da área de controle implantes

Na seqüência foi calculada a porcentagem da densidade ótica da área de controle implante de cada período individualmente, em relação à média conforme equação 4.2:

PorTiDI: média x 100 / TiDI (onde i= período 1, 2 ou 3)

PorTiEl: média x 100 / TiDI (onde i= período 1,2 ou 3)

Equação 4.2: Porcentagens das densidades óticas da área de controle implante

Onde:

- PorTiDI: porcentagem que a densidade ótica da área de controle implante no período i, representa em relação à média da densidade ótica da área de controle implante direita nos três períodos. (onde i= período 1,2 ou 3 )

- PorTiEl: porcentagem que a densidade ótica da área de controle implante no período i, representa em relação à média da densidade ótica da área de controle implante esquerda nos três períodos. (onde $\mathrm{i}=$ período 1,2 ou 3 ) 
Após a obtenção das porcentagens foi feita a correção dos valores das densidades da área de interesse osso + implante em T1, T2 e T3, aplicando o percentual obtido da área de controle implantes, obteve-se as densidades óticas da área de interesse osso + implante corrigidas conforme descrição a seguir:

- T1DOICor - Densidade ótica no período 1 da área de interesse osso + implante da metade direita corrigida.

- T2DOICor - Densidade ótica no período 2 da área de interesse osso + implante da metade direita corrigida.

- T3DOICor - Densidade ótica no período 3 da área de interesse osso + implante da metade direita corrigida.

- T1EOICor - Densidade ótica no período 1 da área de interesse osso + implante da metade esquerda corrigida.

- T2EOICor - Densidade ótica no período 2 da área de interesse osso + implante da metade esquerda corrigida.

- T3EOICor - Densidade ótica no período 3 da área de interesse osso + implante da metade esquerda corrigida.

Utilizando as medidas corrigidas da densidade ótica da área de interesse osso + implante em cada período e em cada lado, calculamos as variações percentuais do segundo período (T2) e do terceiro período (T3) em relação ao primeiro período (T1) (data da realização do implante), para cada lado do implante, independentemente. O cálculo das variações está representado na equação 4.3.

$$
\begin{aligned}
& \mathrm{P} 1 \mathrm{DOI}=(\mathrm{T} 2 \mathrm{DOICor}-\mathrm{T} 1 \mathrm{DOICor}) / \mathrm{T} 1 \mathrm{DOICor}){ }^{*} 100 \\
& \text { P2DOI }=((\text { T3DOICor }- \text { T1DOICor }) / \text { T1DOICor })^{\star} 100 \\
& \text { P1EOI }=((\text { T2EOICor }- \text { T1EOICor }) / \text { T1EOICor })^{*} 100 \\
& \text { P2EOI }=((\text { T2DOICor }- \text { T1EOICor }) / \text { T1EOICor })^{*} 100
\end{aligned}
$$


Equação 4.3: Variação percentual da área de interesse osso+implante corrigida nos períodos analisados.

A variação percentual representa a porcentagem de reabsorção ou não do osso, na área de estudo junto ao implante.

Para cada controle foram obtidos os seguintes parâmetros:

- P1DOI - Variação percentual da densidade ótica na área de interesse osso + implante da metade direita nos primeiros 6 meses

- P1EOI - Variação percentual da densidade na área de interesse osso + implante da metade esquerda nos primeiros 6 meses

- P2DOI - Variação percentual da densidade na área de interesse osso + implante da metade direita nos últimos 12 meses

- P2EOI - Variação percentual da densidade na área de interesse osso + implante da metade esquerda nos últimos 12 meses

\subsection{Método estatístico}

Para a realização da análise estatística, as amostra foram consideradas independentes, realizando-se uma análise temporal dos dados.

$\mathrm{Na}$ análise dos dados do experimento, após as correções descritas acima, foram utilizadas análises descritivas dos dados, obtendo-se as medidas de tendência central (número da amostra, média e mediana) e medida de dispersão (desvio padrão, valores mínimo e máximo).

Foi realizada uma análise de correlação entre os dados temporais e laterais. 
Utilizou-se o método estatístico Análise de Variância com medidas repetidas (WINER, 1971) para testar a igualdade das medias amostrais.

\subsection{1 medidas descritivas}

Foram realizadas medidas descritivas e de dispersão (número da amostra, média, desvio padrão, mínimo e máximo) para as densidades óticas da área de interesse osso + implante para cada lado independentemente (direito e esquerdo) e para cada período (T1, T2 e T3).

As mesmas medidas descritivas foram obtidas das variações percentuais do segundo período e terceiro período em relação ao primeiro período (T1), independente se houve aumento ou diminuição da densidade.

Outras medidas descritivas foram obtidas das variações percentuais entre os diferentes períodos e foram analisados estratificadamente os implantes que obtiveram aumento e os que tiveram diminuição da densidade nos períodos T2 em relação a T1; T3 em relação a T1 e T3 em relação a T2.

\subsection{2 correlação}

Visando identificar um relacionamento estatístico entre as densidades de cada período e cada lado, foi realizada uma medida de correlação dos valores 
observados, buscando identificar a força de relacionamento entre os parâmetros propostos (tempo e lado).

O grau de relacionamento entre as variáveis é sintetizado por um coeficiente de correlação conhecido como $r$ de Pearson variando de $-1,00$ a $+1,00$ que demonstra a força de correlação entre os dados.

\subsection{3 análise de variância}

A análise de variância foi aplicada à densidade ótica e à variação percentual com valores corrigidos.

A análise de aceitação da nulidade $(\mathrm{Ho})$ ocorreu através da análise do pvalue. O nível de confiança utilizado foi $95 \%, p$-value $=0,05$.

Portanto quando $p$-value $=0,05$, admitimos que Ho é verdadeira, rão sendo estatisticamente significante, portanto as diferenças observadas entre as medias amostrais são devidas a variações aleatórias da amostra e considerando-se que as médias populacionais são iguais.

As análises de variância foram realizadas para as seguintes variáveis:

- Densidade

- Variação percentual

- Densidade, comparando os lados Direito e Esquerdo

Densidade comparando os períodos 
4.3.4 teste de significância

O Teste de ajuste Bonferroni foi utilizado para validar a análise de variância realizada com as variações percentuais da densidade da área de interesse osso+implante e a variação na área de controle implante entre os períodos. 


\section{RESULTADOS}

\subsection{Análise exploratória dos dados}

A partir da amostra inicial de 60 implantes e após análise exploratória dos dados, foi possível observar que 3 implantes apresentavam deficiência de medidas no segundo e terceiro período (T2 e T3) e após verificação, fi constatado que os implantes haviam sido removidos portanto foram extraídos da amostra, restando inicialmente 57 implantes.

Posteriormente por meio de uma análise estatística, realizada no Minitab 14, utilizando gráfico Box Plot foi possível identificar dados discrepantes em algumas medidas de 9 implantes nas porcentagens das densidades óticas em relação à média da densidade da área de controle implante (PorTiDI e PorTiEl, onde i= 1, 2 ou 3), que após analisados foram retirados da amostra, provavelmente devido à dificuldade de padronização da tomada radiográfica nos implantes localizados distalmente (Gráfico 5.1)

Após a retirada dos dados discrepantes, um novo gráfico de Box Plot foi realizado com a amostra restante de 48 implantes, onde observourse que todos os dados encontravam-se dentro do intervalo esperado a um índice de confiança de 90\% (Gráfico 5.2). 


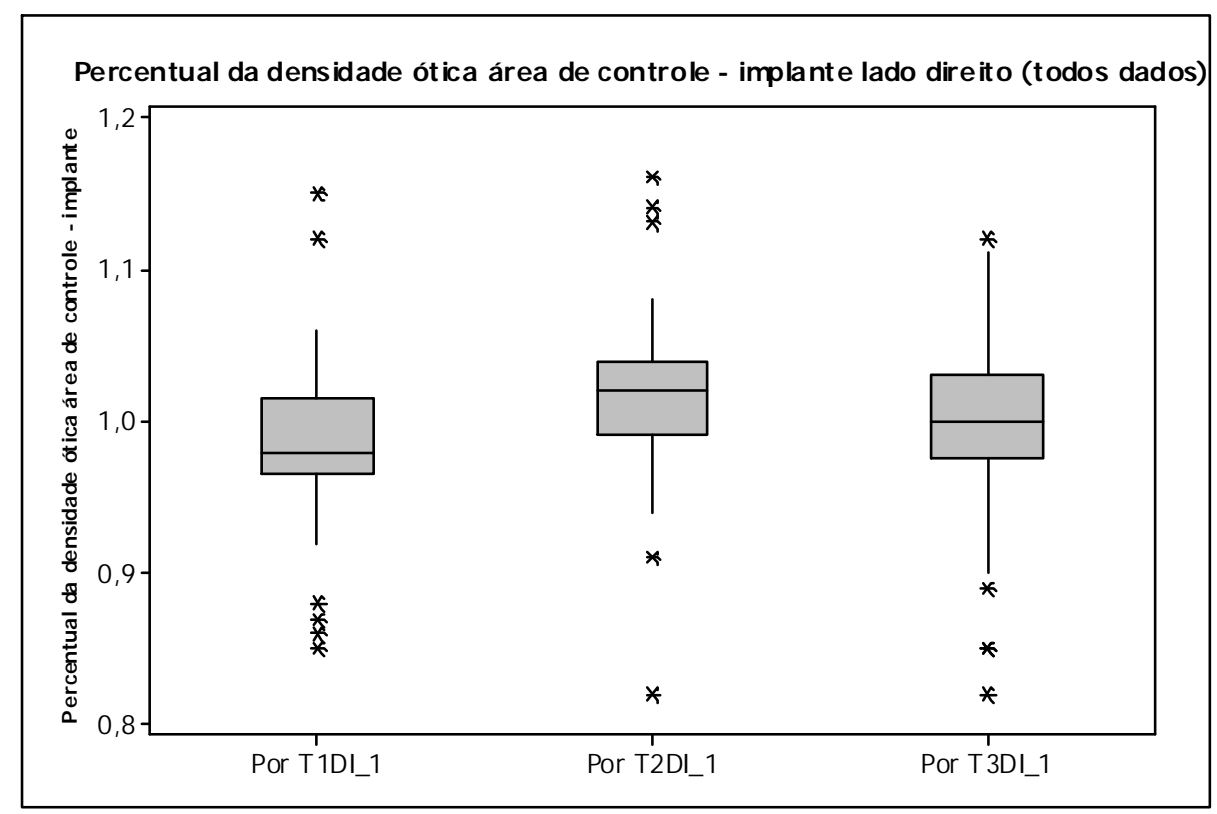

Gráfico 5.1 - Box Plot do percentual da densidade ótica da área de controle implante em relação à média das densidades óticas da área de controle implante do lado direito, com 57 dados amostrais

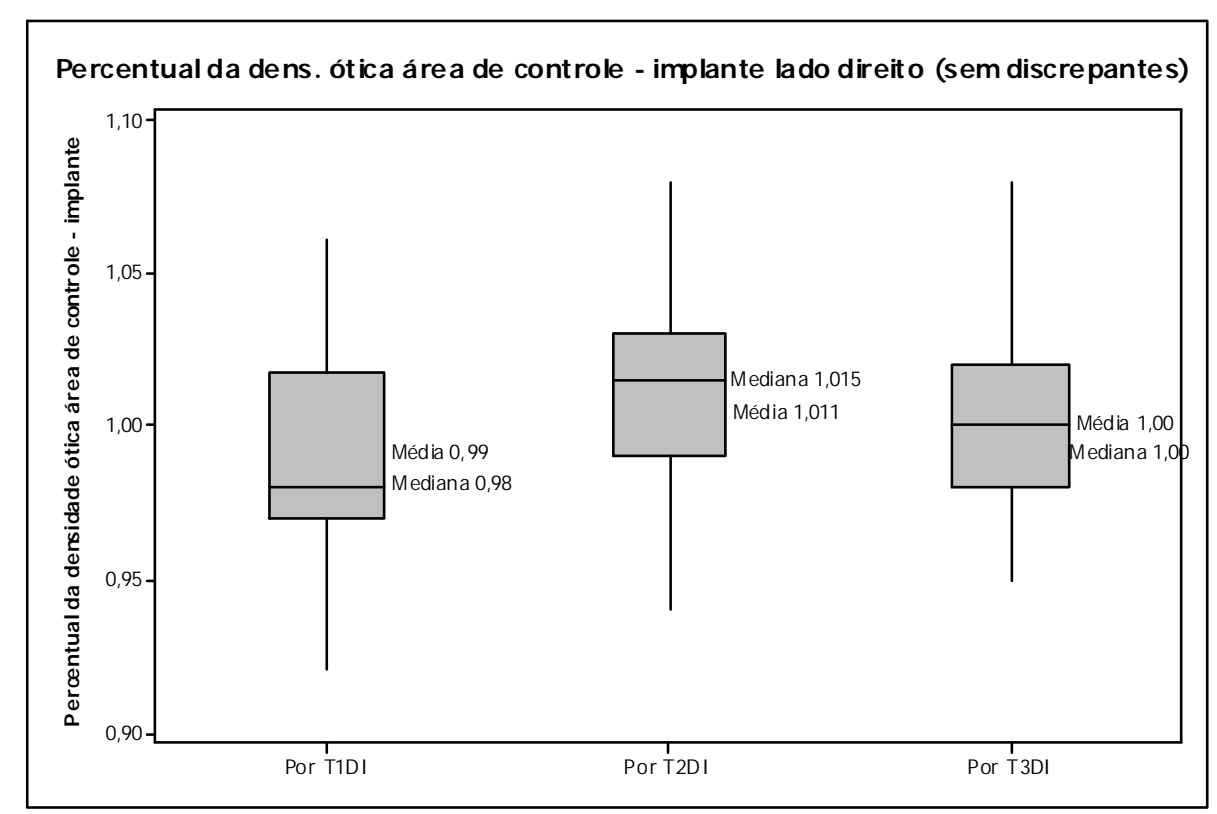

Gráfico 5.2 - Box Plot do percentual da densidade ótica da área de controle implante em relação à média das densidades óticas da área de controle implante do lado direito, sem os dados discrepantes

O gráfico Box Plot apresenta as características da distribuição da amostra com as respectivas mediana e média. Pode-se observar que no lado direito (Gráfico 5.2) em T1 e T2, as medianas apresentam-se deslocadas em relação à média e em T3 
apresentam-se coincidentes, tratando-se portanto, neste caso, de uma distribuição simétrica.

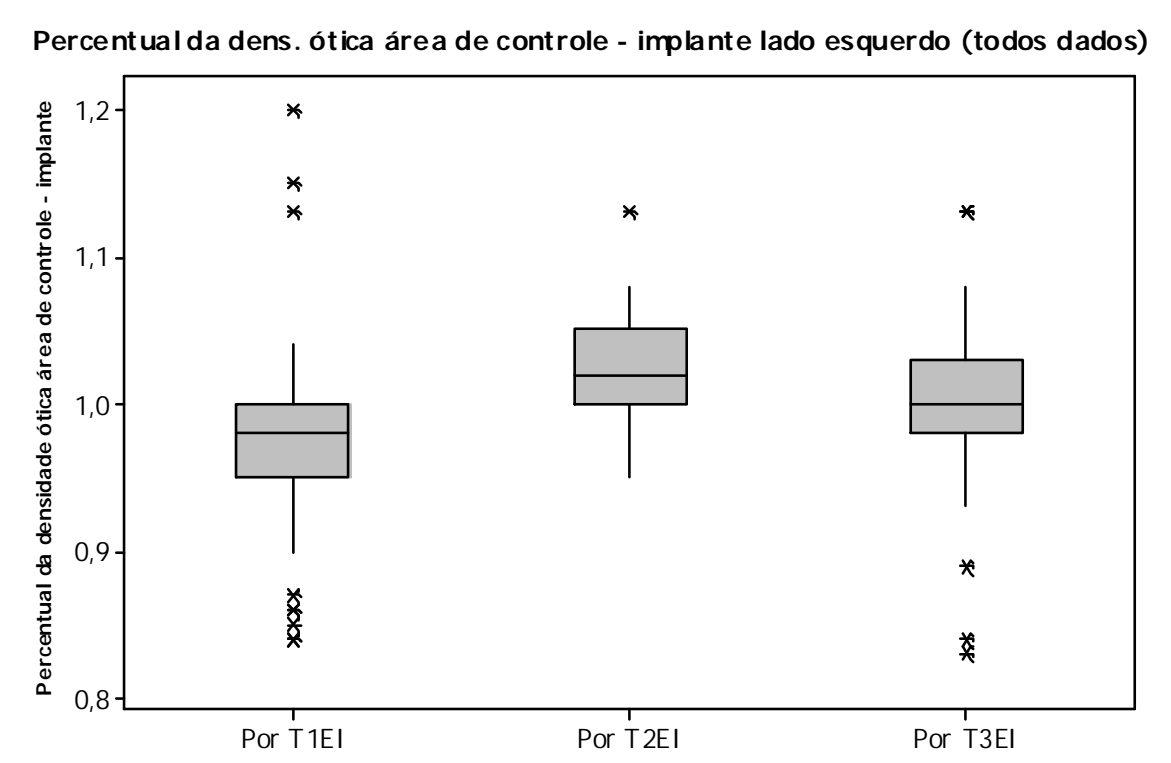

Gráfico 5.3 - Box Plot do percentual da densidade ótica da área de controle implante em relação à média das densidades óticas da área de controle implante do esquerdo, com 57 dados amostrais

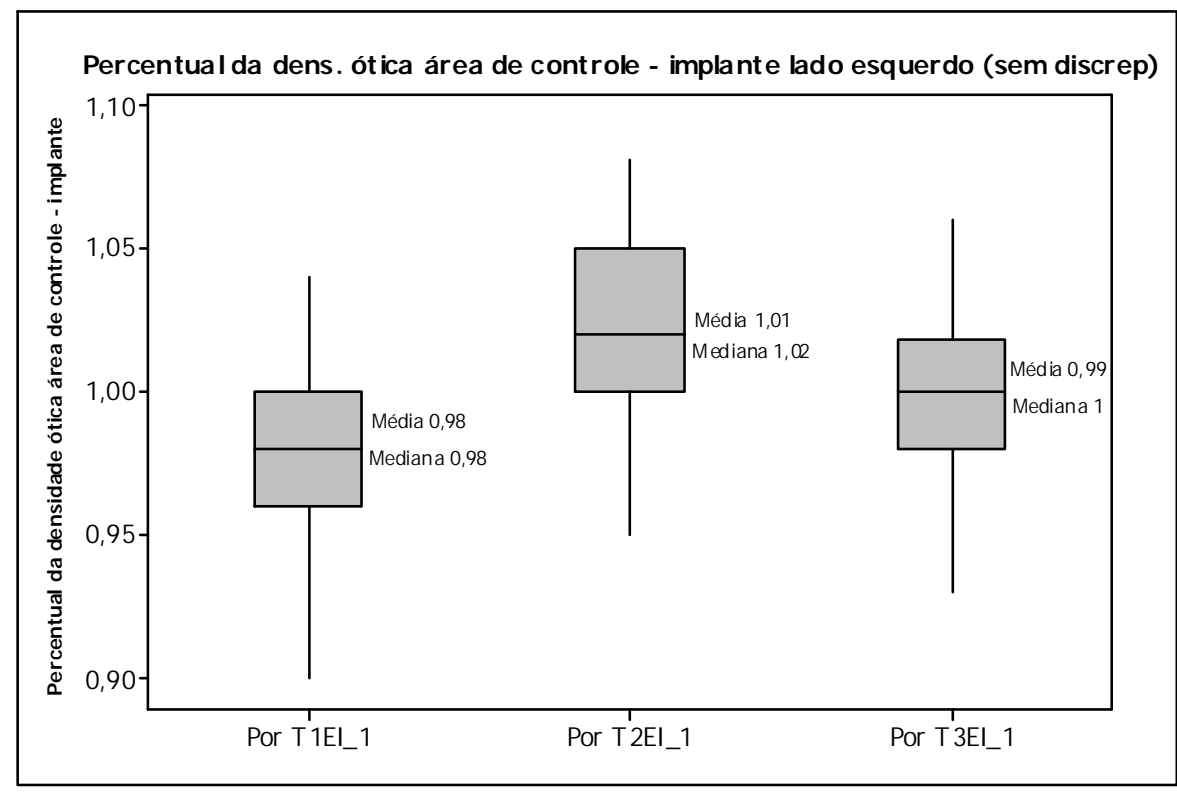

Gráfico 5.4 - Box Plot do percentual da densidade ótica da área de controle- implante em relação à média das densidades óticas da área de controle- implante do lado esquerdo, sem os dados discrepantes 
No lado esquerdo (Gráfico 5.4) em T1 a mediana e a média apresentam-se coincidentes, tratando-se portanto de uma distribuição simétrica.

\subsection{Análises gráficas dos dados}

5.2.1 análise das densidades óticas da área de interesse osso + implante, sem correção

A seguir são apresentadas análises gráficas da densidade ótica da área de interesse osso + implante sem correção (TiDOI e TiEOI onde $\mathrm{i}=1,2$ e 3 ) dos 48 implantes conforme Gráficos 5.5 e 5.6 .

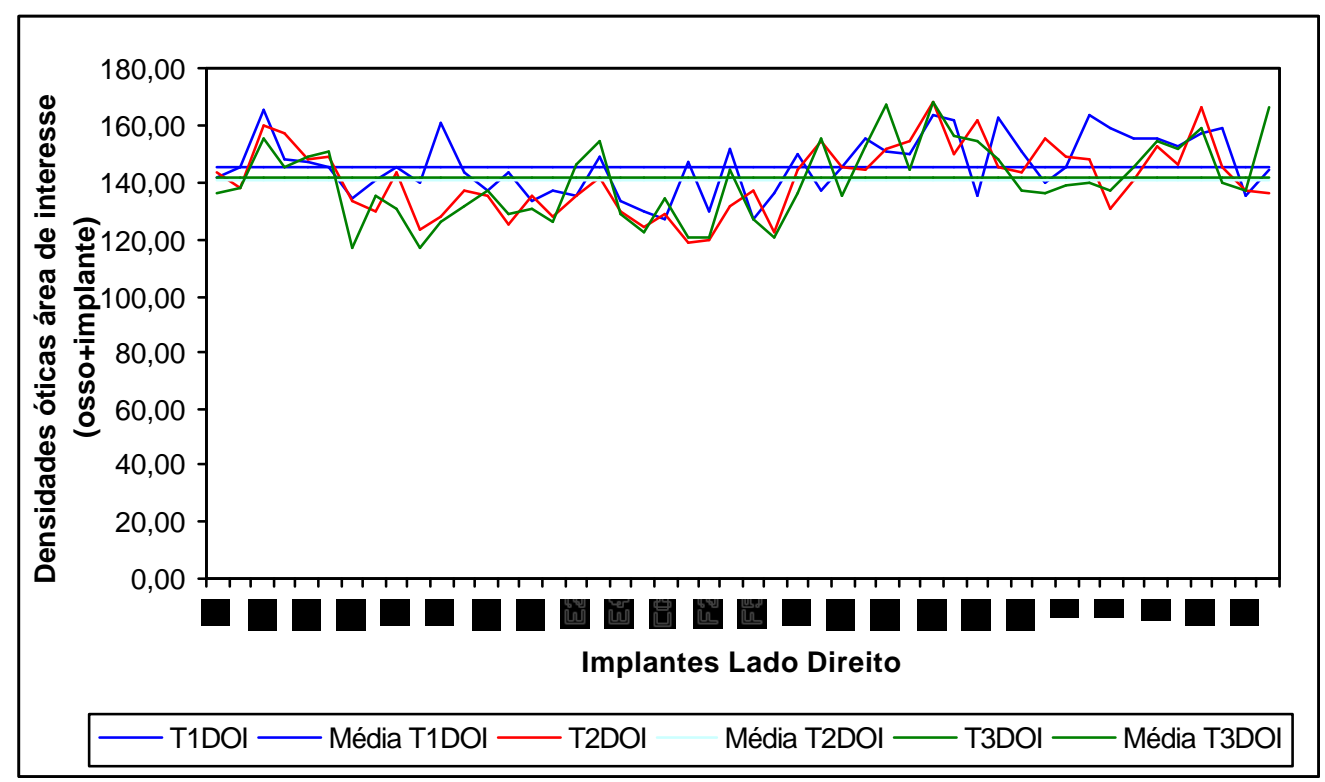

Gráfico 5.5 - Gráfico da densidade ótica da área de interesse (osso + implante) do lado direito (TiDOI onde $\mathrm{i}=1,2,3)$ sem correção e respectivas médias 


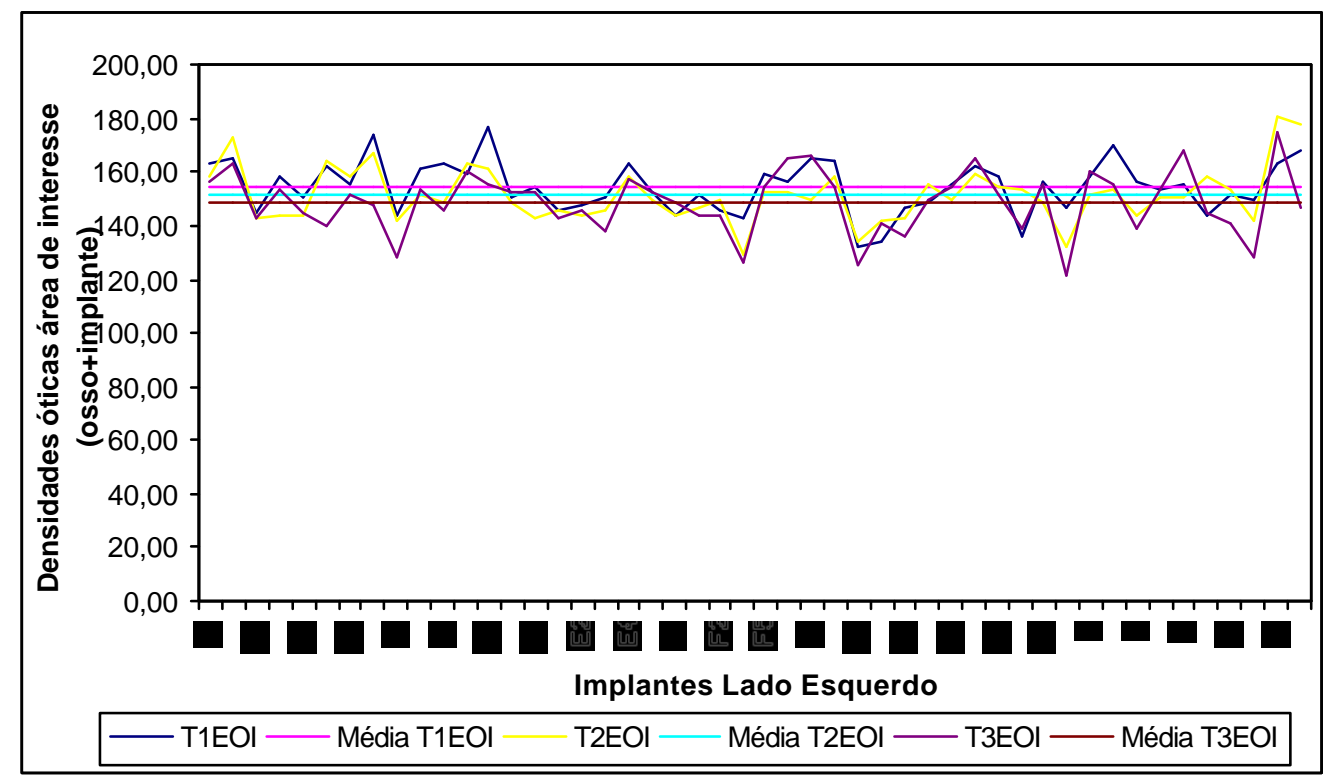

Gráfico 5.6 - Gráfico da densidade ótica da área de interesse (osso+ implante) do lado esquerdo (TiEOI onde $\mathrm{i}=1,2,3$ ) sem correção e respectivas médias

5.2.2 análise das densidades óticas da área de interesse osso + implante após correção

Os Gráficos 5.7 e 5.8 apresentam os valores corrigidos das densidades óticas da área de interesse osso + implante nos lados direito e esquerdo respectivamente, utilizando-se as porcentagens obtidas da densidade ótica da área de controle implante em função das respectivas médias (TiDOICor e TiEOICor). 


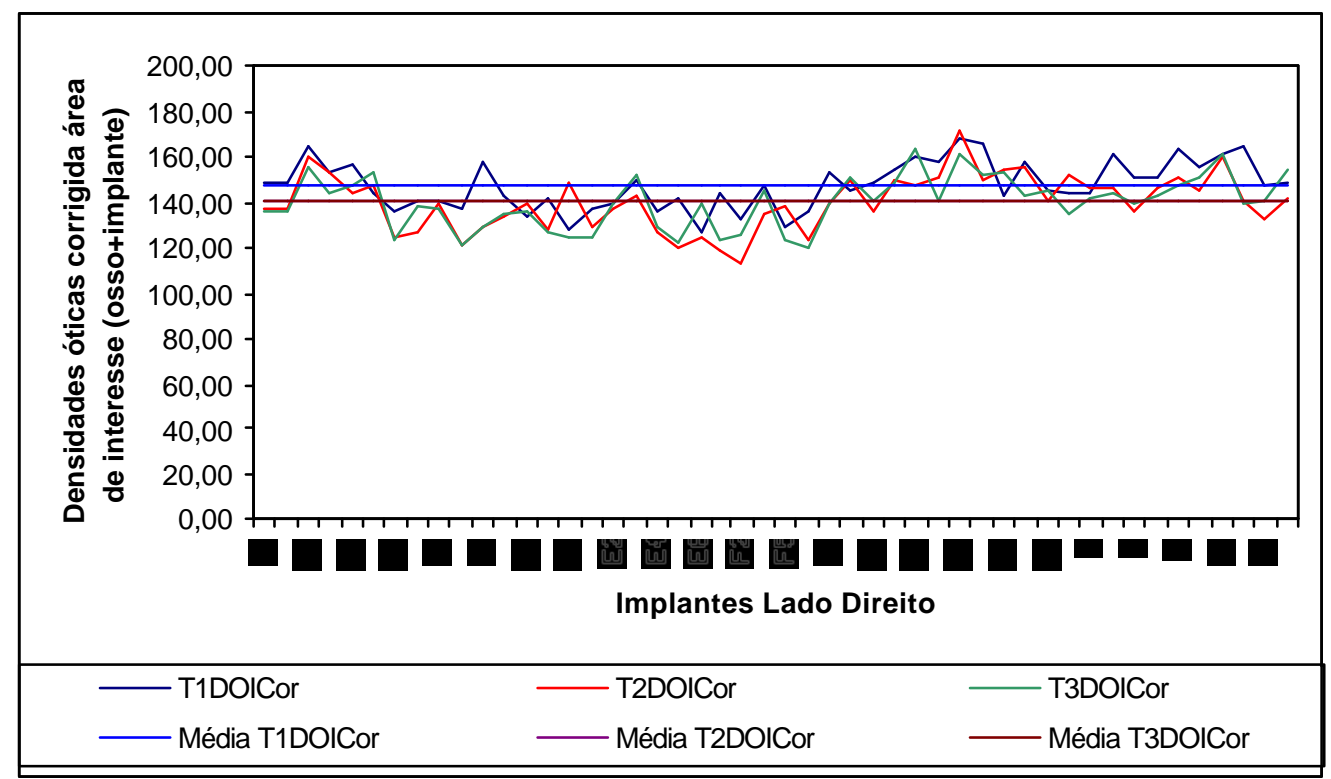

Gráfico 5.7 - Gráfico da densidade ótica corrigida da área de interesse osso+ implante do lado direito (TiDOI Cor onde $\mathrm{i}=1,2,3$ ) e respectivas médias

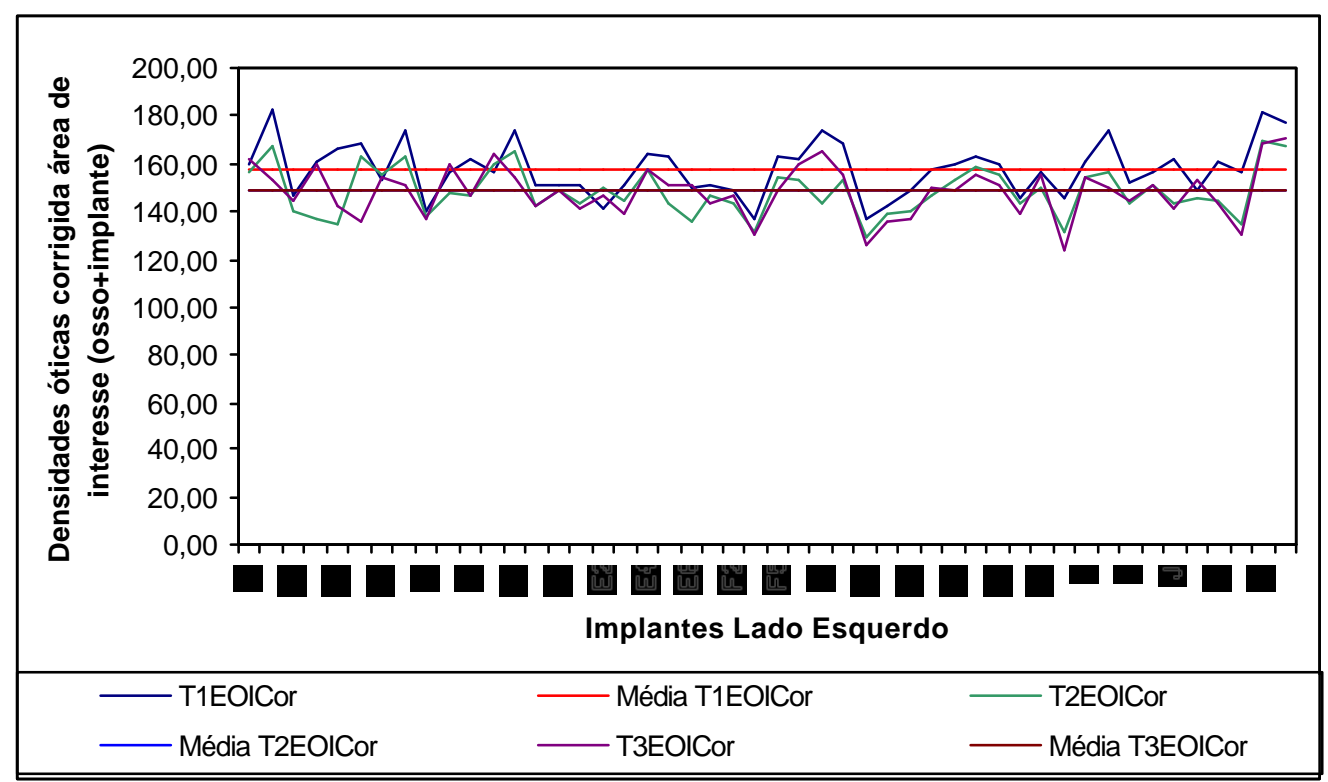

Gráfico 5.8 - Gráfico da densidade ótica corrigida da área de interesse osso+ implante do lado esquerdo (TiEOI Cor onde $\mathrm{i}=1,2,3$ ) e respectivas médias

Pode-se observar que em ambos os lados as densidades óticas corrigidas da área de interesse (osso+ implante) apresentam-se concentrada dentro de uma faixa de valores com médias próximas. 
O Gráfico 5.9 apresenta um gráfico tipo Box Plot, que permite observar a concentração dos valores em blocos e identificar o comportamento da mediana ao longo dos três períodos (T1, T2 e T3). Pode-se perceber que ocorre uma queda maior das densidades óticas da área de interesse osso + implante corrigidas do primeiro para o segundo período, entretanto entre o segundo e terceiro períodos os patamares praticamente se mantêm constantes, tanto para o lado esquerdo como para o lado direito. Notamos também que o lado direito parece apresentar níveis de densidades menores que o lado esquerdo.

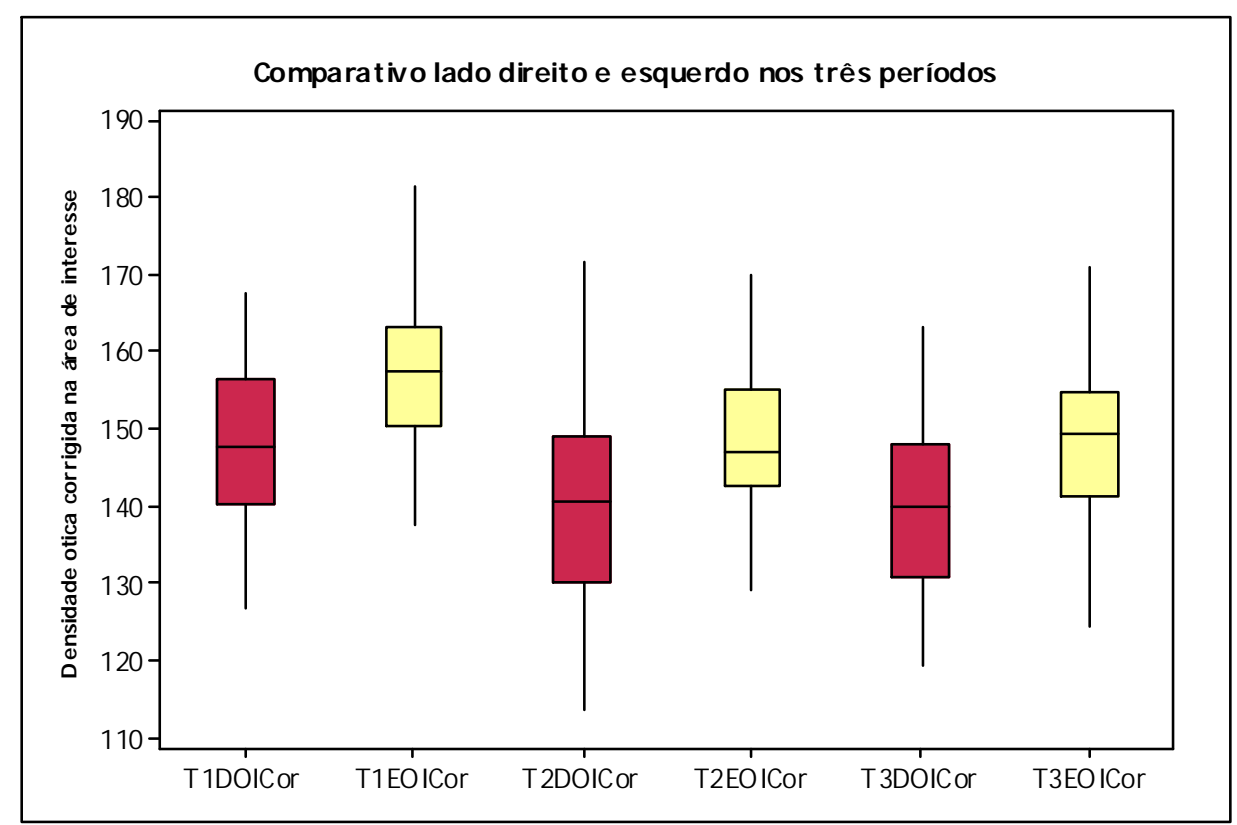

Gráfico 5.9 - Box plots da densidade osso + implante corrigida ao longo do tempo para os dois lados

O Gráfico 5.10 apresenta as variações percentuais das densidades óticas da área de interesse osso + implante em relação ao primeiro período, para cada lado. Pode-se observar que praticamente não se apresentam variações entre os períodos, em ambos os lados. 


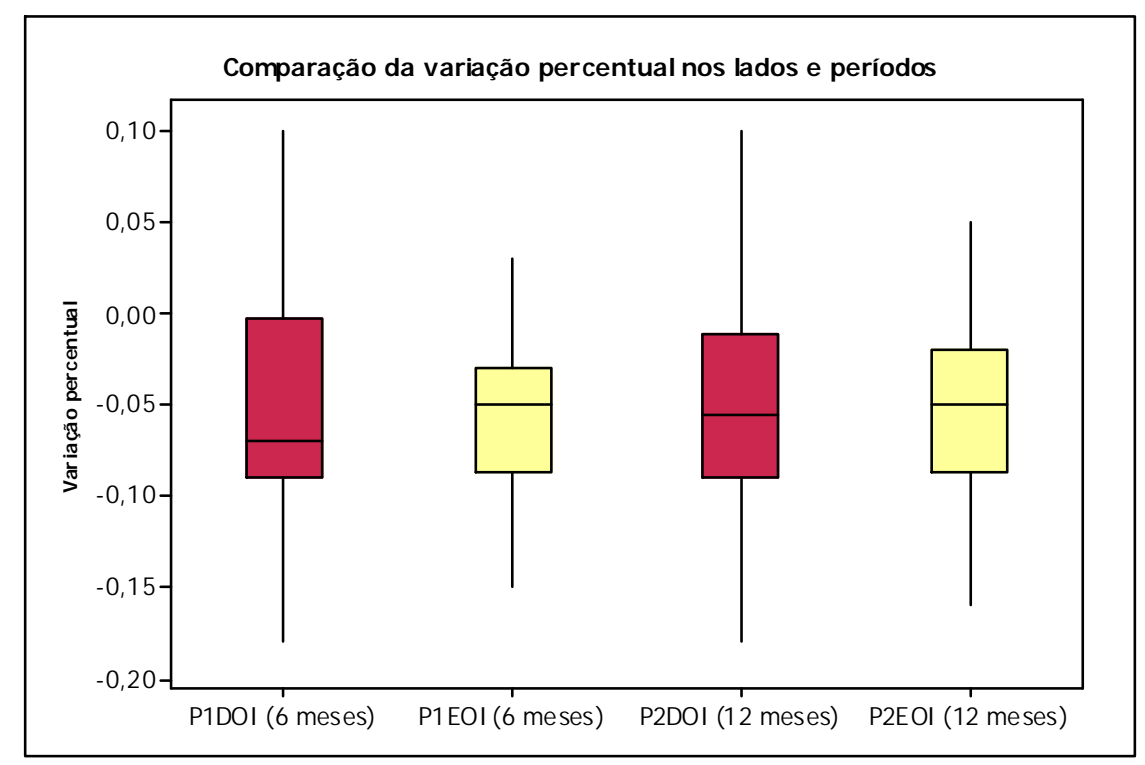

Gráfico 5.10 - Box plots da variação percentual ao longo do tempo para os dois lados

\subsection{Análise das medidas descritivas da densidade ótica corrigida na área de interesse}

A Tabela 5.1 apresenta as medidas descritivas (número da amostra, média, desvio padrão, valores mínimo e máximo) da densidade ótica corrigida da área de interesse osso + implante para cada lado e nos três períodos.

Pode-se observar que para o lado direito apresenta uma queda de 7,6 unidades na média entre o primeiro período e o segundo período e uma queda de apenas 0,04 unidade entre o segundo e o terceiro período. Para o lado esquerdo, o comportamento é similar, entretanto observa-se uma queda mais acentuada, de 9,3 unidades do primeiro para o segundo período e queda de 0,02 unidade do segundo para o terceiro período. 
Tabela 5.1 - Medidas descritivas das densidades óticas corrigidas da área de interesse osso + implante para cada um dos lados e nos períodos

\begin{tabular}{lllll}
\hline Lado & Estatísticas & $\mathbf{T 1}$ & $\mathbf{T 2}$ & T3 \\
\hline \multirow{4}{*}{ Direito } & $\mathrm{N}$ & 48 & 48 & 48 \\
& Média & 147,62 & 140,04 & 140,08 \\
& Desvio Padrão & 10,35 & 12,20 & 11,38 \\
& Mínimo & 126,80 & 113,57 & 119,63 \\
& Máximo & 167,64 & 171,73 & 163,00 \\
& $\mathrm{~N}$ & 48 & 48 & 48 \\
Esquerdo o & Média & 157,76 & 148,43 & 148,41 \\
& Desvio Padrão & 11,08 & 10,08 & 10345 \\
& Mínimo & 137,38 & 129,23 & 124,45 \\
& Máximo & 182,58 & 169,84 & 171,00
\end{tabular}

5.3.1 análise das medidas descritivas das variações percentuais das densidades óticas na área de interesse osso + implante

Os Gráficos 5.11 e 5.12 apresentam as freqüências das variações percentuais da densidade ótica na área de interesse osso + implante nos primeiros 6 meses nos lados direito e esquerdo respectivamente. 


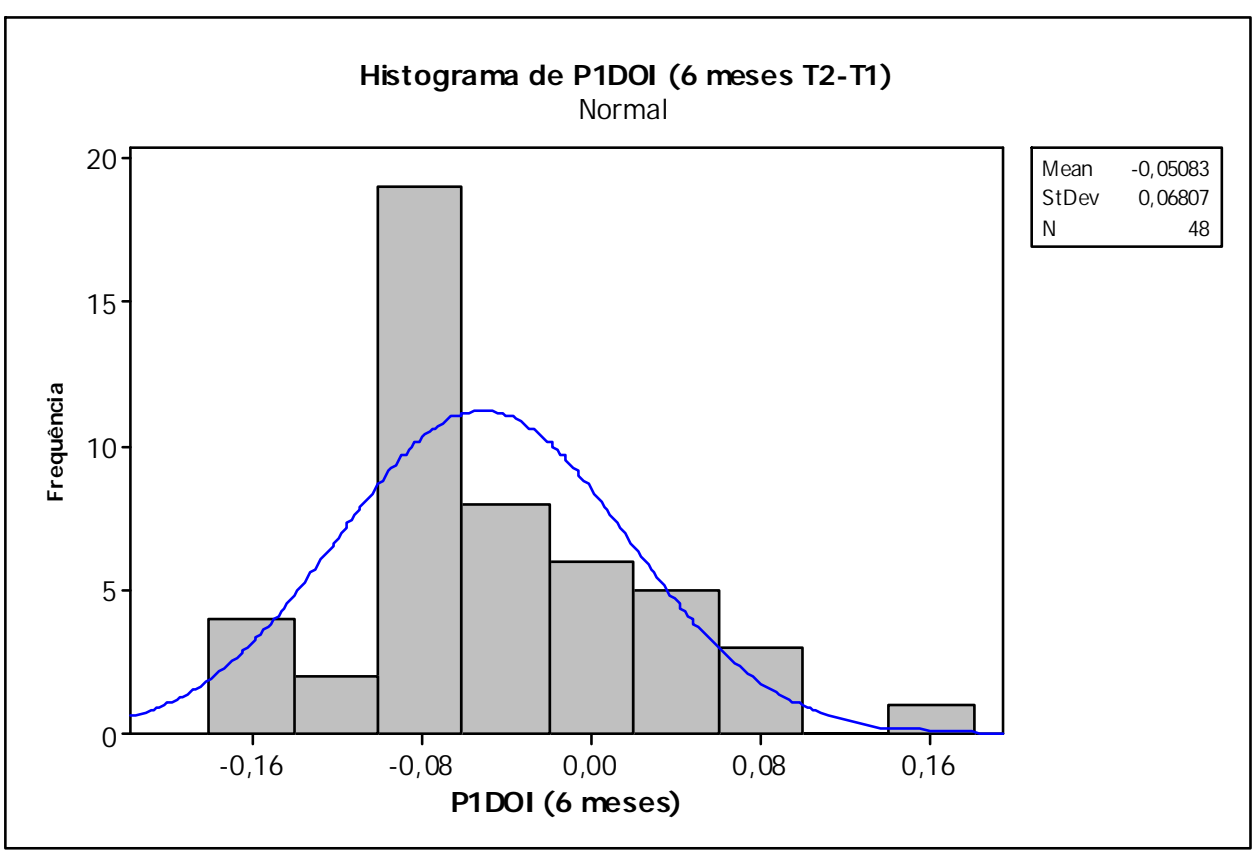

Gráfico 5.11 -Histograma das variações percentual da densidade ótica na área de interesse osso + implante os primeiros 6 meses no lado direito

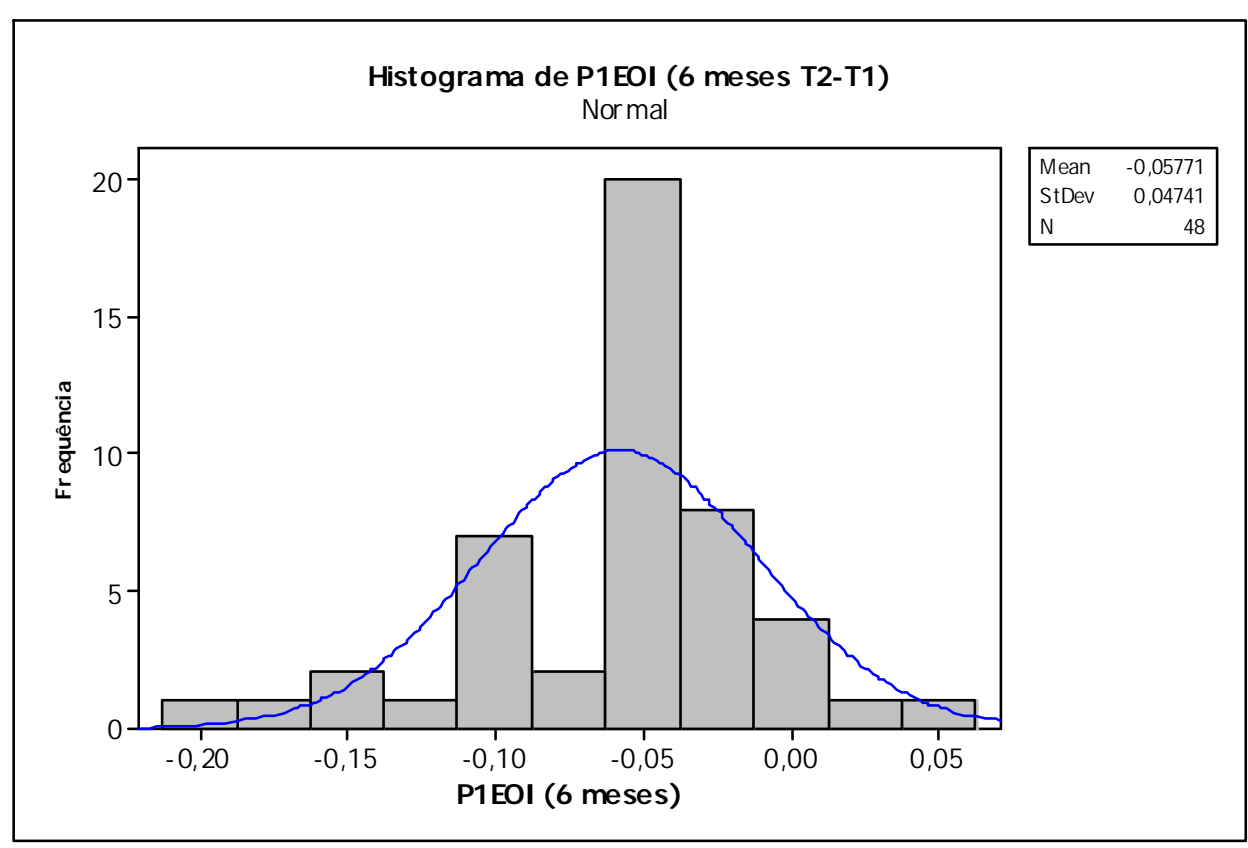

Gráfico 5.12 -Histograma das variações percentual da densidade ótica na área de interesse osso + implante os primeiros 6 meses no lado esquerdo 
Os Gráficos 5.13 e 5.14 apresentam as freqüências das variações percentuais da densidade ótica na área de interesse osso + implante nos 12 meses nos lados direito e esquerdo respectivamente.

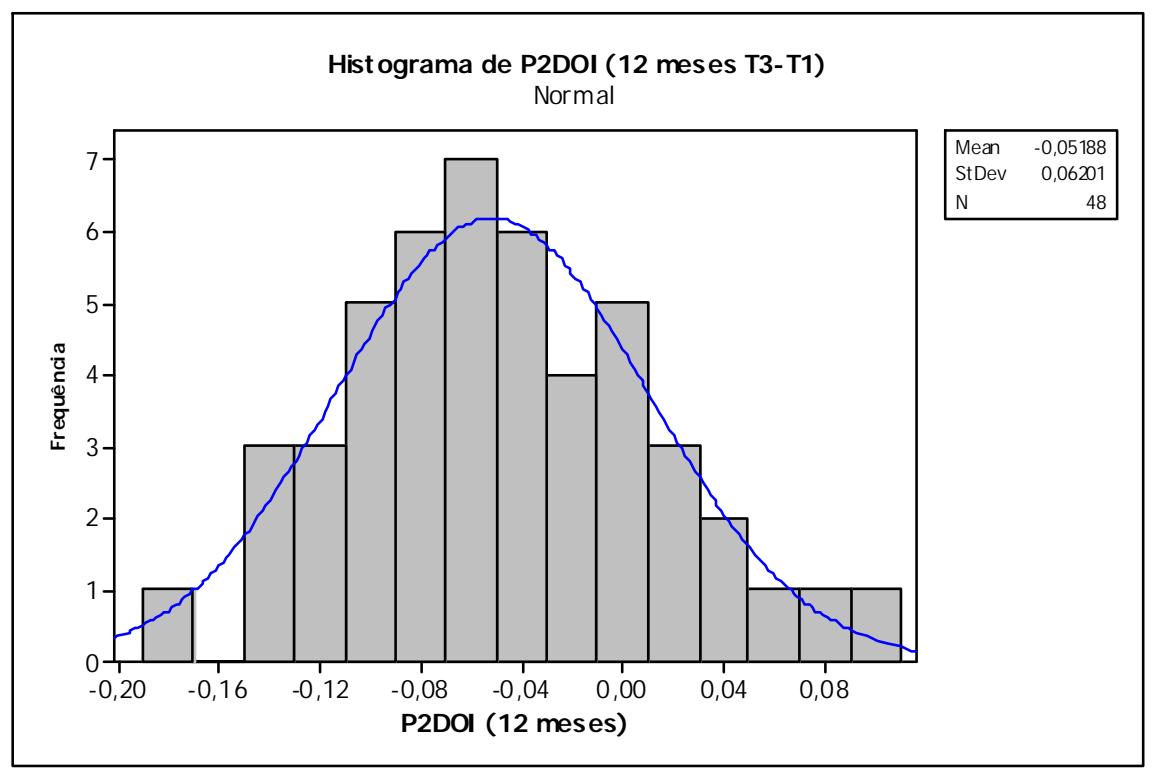

Gráfico 5.13 -Histograma das variações percentual da densidade ótica na área de interesse osso + implante nos 12 meses no lado direito

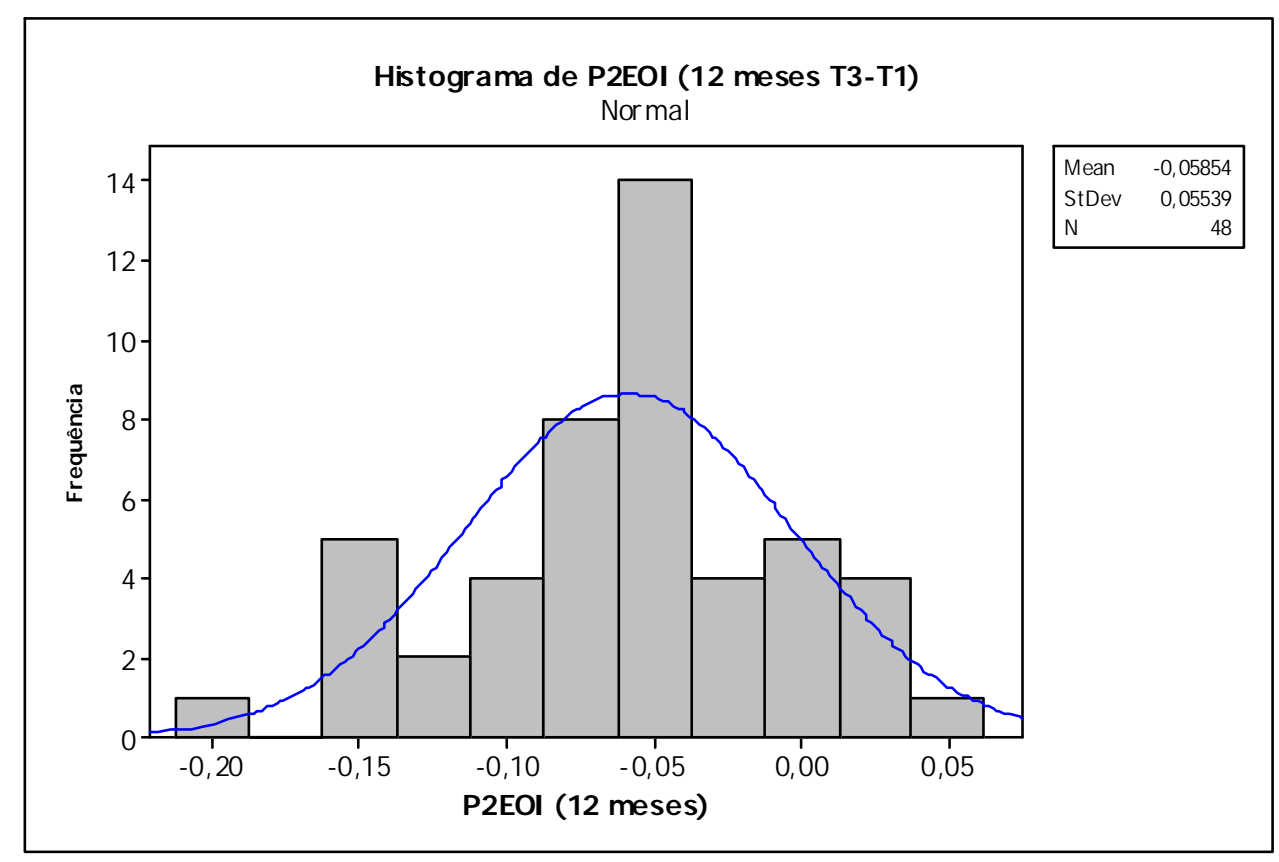

Gráfico 5.14 -Histograma das variações percentual da densidade ótica na área de interesse osso + implante nos 12 meses no lado esquerdo 
Os valores médios da variação percentual da densidade ótica da área de interesse osso + implante podem ser vistos na Tabela 5.2. Pode-se notar uma queda um pouco menor para o lado direito, 5.0\% nos dois períodos, em comparação com $6 \%$ de queda nos dois últimos períodos para o lado esquerdo, o que pode ser confirmado no Gráfico 5.8. Pode-se observar que ocorreu maior reabsorção no lado esquerdo do implante.

Tabela 5.2 - Medidas descritivas da variação percentual da densidade ótica corrigida da área de interesse osso + implante dos períodos T2 e T3 em relação ao período T1

\begin{tabular}{cccc}
\hline Lado & Estatística & T2 & T3 \\
\hline \multirow{4}{*}{ Direito } & $\mathrm{N}$ & 48 & 48 \\
& Média & $-5 \%$ & $-5 \%$ \\
& Desvio Padrão & $7 \%$ & $6 \%$ \\
& Mínimo & $-18 \%$ & $-18 \%$ \\
& Máximo & $15 \%$ & $10 \%$ \\
\multirow{5}{*}{ Esquerdo } & $\mathrm{N}$ & 48 & 48 \\
& Média & $-6 \%$ & $-6 \%$ \\
& Desvio Padrão & $5 \%$ & $6 \%$ \\
& Mínimo & $-19 \%$ & $-19 \%$ \\
& Máximo & $6 \%$ & $5 \%$ \\
\hline
\end{tabular}

A variação percentual média da densidade também foi avaliada considerando o aumento ou diminuição da densidade.

A Tabela 5.3 apresenta a variação percentual da densidade ótica de T2 para $\mathrm{T} 1$, onde podemos verificar que do total de 48 implantes realizados, $75 \%$ apresentou diminuição da densidade ótica da área de interesse osso + implante quando analisado o lado direito e $94 \%$ no lado esquerdo.

No lado direito, 12 implantes tiveram aumento da densidade ótica da área de interesse ossos + implante, em média aumentaram $4.11 \%$ a densidade ótica enquanto no lado esquerdo apenas 3 implantes apresentaram aumento da densidade, em média de 3.39\%. 
Tabela 5.3 - Medidas descritivas da variação percentual do segundo período (T2) em relação ao primeiro período (T1) (P2DOI e P2EOI) estratificados por aumento ou diminuição da densidade ótica corrigida da área de interesse osso + implante

\begin{tabular}{ccccccc}
\hline \multirow{2}{*}{ Estatísticas } & \multicolumn{3}{c}{ direito } & \multicolumn{3}{c}{ esquerdo } \\
\cline { 2 - 7 } & diminuição & aumento & Total & diminuição & aumentou & Total \\
\hline $\mathrm{N}$ & 36 & 12 & 48 & 45 & 3 & 48 \\
Média & $-8.06 \%$ & $4.11 \%$ & $-5,02 \%$ & $-6.39 \%$ & $3.39 \%$ & $-5.78 \%$ \\
Desvio-padrão & $4.22 \%$ & $4.53 \%$ & $6,81 \%$ & $4.15 \%$ & $2.44 \%$ & $4.32 \%$ \\
Mediana & $-7,98 \%$ & $2.76 \%$ & $-6.54 \%$ & $-5.59 \%$ & $2.52 \%$ & $-5.24 \%$ \\
Mínimo & $-18.18 \%$ & $-4.70 \%$ & $-18,18 \%$ & $-19.06 \%$ & $1.50 \%$ & $-17.65 \%$ \\
Máximo & $-0.99 \%$ & $15.47 \%$ & $15,47 \%$ & $-1.30 \%$ & $6.14 \%$ & $6.14 \%$ \\
\hline
\end{tabular}

A Tabela 5.4 apresenta a variação percentual da densidade ótica de T3 para $\mathrm{T} 1$, onde podemos verificar que do total de 48 implantes realizados, $77 \%$ apresentaram diminuição da densidade ótica quando analisado o lado direito e 85\% no lado esquerdo.

No lado direito, 11 implantes tiveram aumento da densidade, em média 3.33\% a densidade ótica enquanto no lado esquerdo apenas 7 implantes apresentaram aumento da densidade, em média de $2.41 \%$.

Quando analisada a variação percentual da média das densidades óticas de T3 para T1, nos implantes que apresentaram diminuição, verifica-se um decréscimo médio semelhante de $7.6 \%$, para o lado direito e $7.16 \%$ para o lado esquerdo dos implantes.

Tabela 5.4 - Medidas descritivas da variação percentual do terceiro período (T3) em relação ao primeiro período (T1) (P3DOI e P3EOI) estratificados por aumento ou diminuição da densidade ótica corrigida da área de interesse osso + implante

\begin{tabular}{ccccccc}
\hline \multirow{2}{*}{ Estatísticas } & \multicolumn{3}{c}{ direito } & \multicolumn{3}{c}{ esquerdo } \\
\cline { 2 - 7 } & diminuição & aumentou & Total & diminuição & aumentou & Total \\
\hline N & 37 & 11 & 48 & 41 & 7 & 48 \\
Média & $-7.645 \%$ & $3.33 \%$ & $-4.99 \%$ & $-7.16 \%$ & $2.41 \%$ & $-5.76 \%$ \\
Desvio-padrão & $4.22 \%$ & $3.34 \%$ & $6.01 \%$ & $4.73 \%$ & $1.50 \%$ & $4.71 \%$ \\
Mediana & $-7.11 \%$ & $2.50 \%$ & $5.38 \%$ & $-6.21 \%$ & $2.38 \%$ & $-5.01 \%$ \\
Mínimo & $-18.07 \%$ & $0.09 \%$ & $-18.07 \%$ & $-19.29 \%$ & $0.75 \%$ & $-16.40 \%$ \\
Máximo & $-0.57 \%$ & $10.26 \%$ & $10,26 \%$ & $-0.64 \%$ & $5.11 \%$ & $5.11 \%$ \\
\hline
\end{tabular}


Comparando a variação percentual do terceiro período (T3) em relação ao segundo período (T2) pode-se observar na Tabela 5.5 que houve um relativo equilíbrio no decréscimo médio $48 \%$ dos implantes para lado direito e $56 \%$ para lado esquerdo. Além disso, tanto para o lado esquerdo como para o lado direito, as médias nos dentes em que houve acréscimo e nos dentes em que houve decréscimo estão próximas, $4.06 \%$ aproximadamente no lado direito e $4.45 \%$ aproximadamente no lado esquerdo, bem como para a diminuição, $-3.93 \%$ e $-3.25 \%$ para o lado direito e esquerdo respectivamente.

Tabela 5.5 - Medidas descritivas da variação percentual do terceiro período (T3) em relação ao segundo período (T2) estratificados por aumento ou diminuição da densidade

\begin{tabular}{ccccccc} 
Estatísticas & diminuição & $\begin{array}{c}\text { direito } \\
\text { aumentou }\end{array}$ & Total & diminuição & $\begin{array}{c}\text { esquerdo } \\
\text { aumentou }\end{array}$ & Total \\
$\mathbf{N}$ & 23 & 25 & 48 & 27 & 21 & 48 \\
Média & $-3.93 \%$ & $4.06 \%$ & $0.31 \%$ & $-3.25 \%$ & $4.45 \%$ & $-0.12 \%$ \\
Desvio-padrão & $4.02 \%$ & $3.69 \%$ & $5.54 \%$ & $3.40 \%$ & $4.72 \%$ & $4.25 \%$ \\
Mediana & $-2.36 \%$ & $2.58 \%$ & $0.10 \%$ & $-2.18 \%$ & $3.70 \%$ & $-0.60 \%$ \\
Mínimo & $-15.87 \%$ & $0.08 \%$ & $-15.87 \%$ & $-16.89 \%$ & $-0.45 \%$ & $-16.89 \%$ \\
Máximo & $-0.55 \%$ & $12.71 \%$ & $12.71 \%$ & $-0.51 \%$ & $16.20 \%$ & $16.20 \%$ \\
\hline
\end{tabular}

\subsection{Correlação das medidas da densidade ótica no tempo}

As associações entre as medidas da densidade ótica, correlacionados no tempo e no lado podem ser vistas na Tabela 5.6, demonstra-se que o lado direito quando correlacionados no tempo, apresentam medidas com correlação relativamente forte entre si $(r=0,65, r=0,65$ e $r=0,75)$ bem como no lado esquerdo $(r=0,74, r=0,63$ e $r=-0,68)$. 
Apresentam-se correlações fracas entre os lados direito e esquerdo do implante, todas com $r$ menores que 0.05 , demonstrando que não há relação entre as medidas do lado direito e esquerdo.

Tabela 5.6 - Coeficientes de correlação entre as medidas das densidades óticas.

\begin{tabular}{cccccccc}
\hline Lado & & \multicolumn{3}{c}{ Direito } & \multicolumn{3}{c}{ Esquerdo } \\
\cline { 3 - 8 } & Tempo & T1 & T2 & T3 & T1 & T2 & T3 \\
\hline \multirow{3}{*}{ Direito } & T1 & 1 & 0.65 & 0.65 & 0.05 & -0.18 & -0.19 \\
& T2 & & 1 & 0.75 & $-0,01$ & $-0,06$ & $-0,18$ \\
& T3 & & & 1 & 0,04 & $-0,03$ & $-0,13$ \\
\multirow{4}{*}{ Esquerdo } & T1 & & & & 1 & 0.74 & 0.63 \\
& T2 & & & & 1 & 0.68 \\
& *3 & & & & & 1 \\
\hline significante & com um nível de significância de 5\% & &
\end{tabular}

\subsection{Análise estatística inferencial}

Utilizando-se o modelo de análise de variância com medidas repetidas com nível de confiança 95\% $(p=0,05)$ foi possível analisar a densidade e a variação percentual, a partir dos valores da densidade ótica corrigida da área de interesse osso + implante

Uma comparação entre densidades óticas da área de interesse osso + implante dos diferentes períodos (T1, T2 e T3) foi realizada, conforme resultados apresentados na Tabela 5.7

Comparando o segundo (T2) período com o terceiro período (T3) não obtivemos uma diferença estatisticamente significante $(p=0,93$ e $p=0,99$ para o lado direito e esquerdo respectivamente). 
Comparando o segundo (T2) período com o primeiro período (T1) e o terceiro (T3) período com o primeiro período (T1) obtivemos diferenças estatisticamente significantes ( $p=0,002$ e $p<0,001$ respectivamente).

Tabela 5.7 - Comparações entre os períodos (T1, T2 e T3) para a densidade ótica da área de interesse osso + implante para o lado direito do implante

\begin{tabular}{lcccc}
\hline $\begin{array}{c}\text { Período } \\
(\mathbf{I})\end{array}$ & Período (J) & $\begin{array}{c}\text { Diferença } \\
\text { Média (I-J) }\end{array}$ & F & $\mathbf{p}^{\mathbf{1}}$ \\
\hline 1 & 2 & 7.56 & 9.97 & 0.002 \\
1 & 3 & 0.22 & 0.008 & $<0.001$ \\
2 & 3 & 7.79 & 12.10 & 0.93 \\
\hline & & & \\
& & &
\end{tabular}

Tabela 5.8 - Comparações entre os períodos (T1, T2 e T3) para a densidade ótica da área de interesse osso + implante para o lado esquerdo do implante.

\begin{tabular}{|c|c|c|c|c|}
\hline $\begin{array}{l}\text { Período } \\
\text { (I) }\end{array}$ & Período (J) & $\begin{array}{c}\text { Diferença } \\
\text { Média (I-J) }\end{array}$ & $\mathbf{F}^{2}$ & $p^{1}$ \\
\hline 1 & 2 & 9.24 & 18.62 & $<0.001$ \\
\hline 1 & 3 & 0.014 & 0.00004 & $<0.001$ \\
\hline 2 & 3 & 8.88 & 17.31 & 0.99 \\
\hline
\end{tabular}

Verificamos portanto que as médias das densidades ótica da área de interesse osso + implante para o período T2 e T3, $p=0.93$ e $p=0.99$ para os lados direito e esquerdo respectivamente não são estatisticamente significantes, podendo atribuir a variação das médias à aleatoriedade da amostra. Portanto pode-se afirmar que as variações percentuais apresentadas nestes períodos são verdadeiras com $95 \%$ de nível de confiança. 


\section{DISCUSSÃO}

A reabilitação protética de áreas edêntulas com a utilização de implantes osteointegrados a partir do protocolo tradicional de dois estágios cirúrgicos, tem apresentado resultados clínicos satisfatórios (BRANEMARK, 1977; VASCONCELOS, 2004).

O protocolo tradicional estabelece a necessidade de se manter os implantes sem forças oclusais incidindo sobre eles, em uma situação que se estenderia por aproximadamente seis meses para a maxila e quatro meses para a mandíbula. Este período inicial de espera é necessário para que ocorra a osteointegração, submetendo os pacientes ao uso de próteses removíveis provisórias ou até mesmo de não utilizarem próteses. O uso destes aparelhos provisórios, desprovidos em alguns casos de estabilidade e retenção, gera situação de desconforto, necessidade de ajustes freqüentes e eventuais problemas psicológicos e de convívio social (NARY FILHO et al., 2004; SOUZA PINTO, 2004).

Um dos enfoques atuais da pesquisa em implantodontia é a redução do tempo de tratamento que visa agilizar e atender às demandas sociais e comportamentais. Em determinados casos, sob condições e circunstâncias favoráveis, é possível a aplicação de um protocolo cirúrgico de um só estágio no qual uma conexão rígida, a partir de implantes, suporta uma prótese construída sobre a mesma que é submetida à carga imediata e ou precoce com resultados satisfatórios (NARY FILHO et al., 2004; SCHNITMAN; WOHRLE; RUBENSTEIN, 1990; SOUZA PINTO, 2004; VASCONCELOS, 2004; VASCONCELOS et al., 2005). 
Segundo Gottlow e Lundgren (2002) e Vasconcelos (2004) a terminologia que deveria ser empregada na literatura em relação ao tempo de instalação da prótese após a cirurgia, é a que define como carga imediata quando a prótese é instalada no mesmo dia do implante; carga precoce quando a prótese é instalada em um segundo procedimento, antes do período convencional, sendo que o tempo de carga deve ser considerado em dias e semanas; carga tardia quando a prótese é instalada em um segundo procedimento, após o período convencional de reparação, ou seja, de três a seis meses.

De acordo com Francischone (2004) o termo carga é algo estático, e o que ocorre na boca é dinâmico, tratando-se de um carregamento e não carga. Assim o termo função imediata seria o mais adequado.

A aplicação de um protocolo bem sucedido para o tratamento do edentulismo com implantes de função imediata e ou precoce acrescenta vantagens e benefícios para o paciente. Podemos citar além da diminuição do custo do tratamento, que a realização de um procedimento cirúrgico único com a eliminação da prótese removível provisória, diminui os riscos para a obtenção da osteointegração, causados pela transmissão de cargas transmucosas a implantes submersos e não unidos durante a fase de reparo (SOUZA PINTO, 2004).

A maior exigência estética e funcional dos pacientes. Faz com que a cada dia desenvolvam-se maneiras de diminuir ou suprimir o tempo de espera para a introdução da prótese funcional. Todavia, se não houver critérios na indicação da carga imediata, a osteointegração das fixações poderá ser prejudicada (VIEGAS et al., 2004). 
Lekholm e Zarb (1985), propuseram uma classificação óssea quantitativa e qualitativa, que em conjunto são fatores determinantes para a obtenção da melhor resistência mecânica.

A quantidade óssea pode ser determinada com segurança por meio de radiografias convencionais e tomografia computadorizada (CHILVARQUER, 1997).

A qualidade óssea, no entanto, pode ser sugerida por meio de radiografias convencionais e tomografia computadorizada, mas a determinação final é baseada na percepção clínica do Cirurgião durante o processo de fresagem e ou de inserção do implante, sendo que os dados obtidos são subjetivos (SOUZA PINTO, 2004).

Segundo Nary Filho et al. (2004), Rocci, Martignoni e Gottlow (2003), Souza Pinto (2004) e Vasconcelos (2004) para a realização do protocolo de carga imediata ou precoce, certas condições devem ser respeitadas. O protocolo deve ser aplicado preferencialmente em pacientes com boa saúde, não fumantes, na ausência de bruxismo, portadores de osso tipo I, II ou III, segundo a classificação de Lekholm e Zarb (1985), com moderada reabsorção óssea e com alta estabilidade primária.

A utilização de procedimentos com protocolo é importante para que os Cirugiões-Dentistas possam utilizar procedimentos clínicos com previsibilidade e em bases rotineiras (LENHARO; COSSO, 2004; SOUZA PINTO, 2004).

A alta estabilidade primária do implante no leito receptor, de acordo com diversos autores, é um pré-requisito importante para a função oclusal precoce e ou imediata (BOGAERD et al., 2003; CALANDRIELLO; TOMATIS; RANGERT, 2003; TORTAMANO NETO; CAMARGO; VEIGA, 2004; VASCONCELOS, 2004).

A estabilidade primária alta está fundamentada no diagnóstico clínico e radiográfico da qualidade do osso, na utilização de técnica adequada de preparação 
do leito ósseo receptor e na seleção correta do tipo de implante (SOUZA PINTO, 2004).

A obtenção da estabilidade primária na instalação de implantes osteointegrados representa um dos principais requisitos para a viabilização dos mecanismos de reparação tecidual que resultam na denominada osteointegração e consiste basicamente no preparo ósseo sob dimensões ligeiramente menores que as dimensões do implante que se pretende instalar. Os parâmetros para a determinação da estabilidade primária representam uma etapa da técnica cirúrgica que depende essencialmente do Cirurgião Dentista (CONSTANTINO, 2004).

Como a estabilidade primária do implante depende da técnica de instrumentação e esta da determinação da qualidade óssea, isso torna o procedimento de instalação de implantes com estabilidade maximizada ainda empírico (CALANDRIELLO; TOMATIS ; RANGERT, 2003; SOUZA PINTO, 2004).

A estabilidade primária é obtida no ato cirúrgico, sendo resultado direto do contato entre o tecido ósseo e a superfície do implante, portanto é de natureza mecânica. Se o implante não obtiver uma boa estabilidade primária é consenso que ele não deva ser submetido à carga funcional, pois é grande a possibilidade de movimentação do mesmo, ocasionando a formação de tecido fibroso ao seu redor e posterior perda, sendo então necessário aguardar a estabilidade secundária, que depende do processo de reparo ósseo, sendo portanto de natureza biológica (OLIVEIRA et al., 2004; VASCONCELOS, 2004).

A reabilitação de mandíbulas edêntulas por meio da submissão de implantes à função imediata é uma modalidade de tratamento com altos índices de sucesso (VASCONCELOS et al., 2005). 
Já a maxila apresenta certas características que podem trazer dificuldades para serem reabilitadas com implantes, tais como acidentes anatômicos característicos: seios maxilares, forame incisivo e fossa nasal e a atrofia severa do processo alveolar, dificultando a estabilidade das próteses, podendo levar os pacientes a um estado de invalidez oral com a conseqüente piora da qualidade de vida.

Anatomicamente os ossos maxilares são constituídos por osso cortical e osso esponjoso. O osso cortical se caracteriza por possuir maior quantidade mineral e menor vascularização, o osso esponjoso, ao contrário, por possuir uma maior vascularização. Enquanto o osso cortical propicia melhor ancoragem ao implante, o esponjoso é mais facilmente remodelado.

$\mathrm{Na}$ maxila, principalmente na região posterior, a estabilidade inicial dos implantes pode não ser suficiente para a utilização da técnica da função oclusal imediata.

A presença de macro e micromovimentos na superfície do implante podem resultar em reparo fibroso na interface osso-implante ao invés de regeneração óssea, o qual pode ser detectado em controle radiográfico periapical, como uma perda óssea marginal nas faces distal e mesial do implante (BRUNSKY, 1992; VASCONCELOS, 2004). A esplintagem rígida e imediata protege contra micromovimentos e previne o direcionamento isolado de cargas oclusais sobre apenas um implante (NARY FILHO et al., 2004; SOUZA PINTO, 2004).

O exame radiográfico no pré-operatório tem como finalidade planejar o número e o tamanho dos implantes, de acordo com a altura e espessura do rebordo ósseo da maxila e da mandíbula, bem como o seu posicionamento em relação as estruturas nobres adjacentes (CHILVARQUER, 1993). 
Os objetivos principais do exame radiográfico no controle pós-operatório são: verificação do nível ósseo perimplantar e suas alterações ao longo do tempo, adaptação entre a fixação e o pilar e entre a prótese e o pilar, fratura do implante e do parafuso de fixação da prótese e diagnóstico das patologias relacionadas aos dentes adjacentes aos implantes que possam alterar o prognóstico da prótese (BRÄGGER, 1998; GRÖNDAHL; EKESTUBBE; GRÖNDAHL, 1996b).

De acordo com a literatura (CHILVARQUER, 1997; HOLLENDER, 1992; STRID, 1985; VEDOVATO; CHILVARQUER, 2001) o controle radiográfico pósoperatório utilizado em protocolos cirúrgicos de dois tempos, deve ser realizado imediatamente após a instalação da prótese, após 6 meses, após 1 ano e anualmente até o terceiro ano seguido por intervalos de 3 anos, ou em casos em que o aparecimento de sinais e sintomas não possam ser diagnosticados sem a utilização de radiografias, sendo extremamente improvável o risco de dano celular causado pela dose de radiação (GRÖNDAHL; EKESTUBBE; GRÖNDAHL, 1996a; STENSTRÖM et al., 1990).

Devido a metodologia empregada no controle radiográfico, ou seja, radiografias periapicais realizadas mensalmente até os seis primeiros meses após a instalação dos implantes, Souza Pinto (2004) observou que a maior perda óssea ocorreu entre a instalação dos implantes e o primeiro mês após e que entre o primeiro e o segundo mês ocorreu uma perda óssea ainda importante, porém menor do que a encontrada até o primeiro mês, diminuindo gradativamente em média até os seis primeiros meses e estabilizando-se até o décimo segundo mês. Estes dados coincidem com os dados observados na literatura sobre implantes realizados em dois estágios os quais conferem ao trauma da reabertura para a instalação da prótese relevante importância na perda óssea. 
Estes resultados obtidos por Souza Pinto (2004) confirmam que o protocolo radiográfico preconizado pela literatura especializada para o controle longitudinal de implantes realizados em dois estágios cirúrgicos, ou seja, radiografias periapicais obtidas imediatamente após a instalação da prótese, seis meses após, doze meses e anualmente, e que foi utilizado em nosso trabalho, também é válido para o controle radiográfico de implantes com função oclusal precoce e ou imediata (BOGAERD et al., 2003).

Os estudos sobre métodos radiográficos convencionais tem demonstrado alta especificidade com baixa sensibilidade em detectar alterações perimplantares (BRÄGGER et al., 1992).

A utilização de sistemas de análise de imagens de radiografias realizadas por computador, propicia maior capacidade de detectar alterações ósseas em relação às técnicas radiográficas convencionais. (BAXES, 1984; BRÄGGER, 1998; BRÄGGER et al., 1991; REDDY; JEFFCOAT; RICHARDSON, 1990; VAN DER STELT; GERAETS, 1991).

De acordo com Baxes (1984), o processamento digital de imagens tem como objetivos, intensificar visualmente ou avaliar estatisticamente alguns aspectos da imagem. O histograma de tons de cinza fornece uma representação da distribuição de cada ponto distinto dentro da imagem digital (pixel) sendo representado sob a forma de um gráfico, tendo em seu eixo horizontal, o brilho, variando de 0 a 255 (escala de 8 bits) e no eixo vertical o número de pixels.

O trabalho de Kullendorf, Nilsson e Rohlin (1996) mostrou que a qualidade da imagem digital direta é comparável a do filme Ektaspeed digitalizado, na detecção de lesão óssea periapical, no entanto, a imagem digital direta não tem sido o método de escolha utilizado em controle longitudinal de implantes verificado na literatura 
especializada consultada. O tamanho do sensor (maior espessura e menor área útil que o filme convencional) e a sua dificuldade no posicionamento intrabucal, especialmente em casos de rebordos extremamente reabsorvidos, o que dificulta a obtenção de radiografias padronizadas, parecem influenciar para a escolha do método digital indireto no controle de implantes.

Uma vasta gama de autores têm utilizado o método digital para a melhor avaliação das alterações ósseas, devido ao fato que o ajuste da densidade e contraste da imagem aumentam a capacidade do observador em detectar pequenos defeitos ósseos (JEFFCOAT, 1992; JEFFCOAT et al., 1996; REDDY; JEFFCOAT; RICHARDSON, 1990; VALE; BRAMANTE; BRAMANTE, 1998; VAN DER STELT, 1996; Van DER STELT; GERAETS, 1991; WENZEL, 1991), sendo que Kullendorff, Nilsson e Rohlin (1996) relataram que não observaram diferenças entre uma imagem digital em sua forma original e uma imagem radiográfica manipulada com as facilidades dos recursos digitais.

Segundo Kullendorff e Nilsson (1996) a qualidade das imagens digitais diretas é comparável à do filme Ektaspped na detecção de lesões ósseas periapicais, sendo que a metodologia empregada neste trabalho consistia de radiografias realizadas com filmes periapicais Ultraspeed, os quais proporcionam maior detalhe na imagem radiográfica por apresentarem uma menor granulação dos cristais de prata.

A osteointegração em condições de normalidade, sugere uma remodelação óssea perimplantar, após a colocação do implante, mostrando radiograficamente áreas radiopacas (osso) ao redor dos mesmos (ADELL et al., 1981; BRÅNEMARK et al., 1977).

Após a instalação de um implante, o osso ao redor da fixação começa a ser substituído por osso novo e, após quatro semanas, a quantidade de osso 
neoformado já é igual a de osso antigo, inicialmente em contato. A qualidade da osteointegração entre o período crítico de zero a seis semanas é melhor nos procedimentos de um estágio, se comparados aos de dois estágios cirúrgicos, baseado na Lei de Wolff, em que a aplicação de carga abaixo do nível de dano pode resultar em hipertrofia óssea (VIEGAS et al., 2004).

A avaliação da perda da osteointegração é evidenciada na radiografia pela presença de imagem radiolúcida perimplantar, podendo indicar falha no tratamento com implantes (ADELL et al., 1981; BRÅNEMARK et al., 1977; SMITH; ZARB, 1989; STRID, 1985).

Os implantes que apresentam radiolucência perimplantar contínua e mobilidade clínica, são diagnosticados como falhos (ADELL et al., 1981; Brånemark et al., 1977; STRID, 1985).

É interessante lembrar o trabalho de Adell et al. (1990) que demonstrou que implantes com áreas radiolúcidas perimplantares mas com ausência de mobilidade clínica, poderiam não estar osteointegrados nas faces proximais (observadas nas radiografias periapicais) mas nas faces vestibular e lingual terem mantido a osteointegração.

Devemos lembrar que a interpretação na radiografia periapical é realizada apenas nas faces mesial e distal do implante não permitindo a avaliação das faces vestibular e lingual, limitando a avaliação do suporte ósseo perimplantar (SMITH; ZARB, 1989).

Usando os critérios para avaliação do sucesso de implantes proposto por Smith e Zarb (1989), é necessário um controle longitudinal realizado com radiografias periapicais padronizadas para avaliação da presença ou ausência de 
radiolucência perimplantar e medir o nível ósseo nas faces interproximais (BRÄGGER, 1998).

Para a execução do controle longitudinal de implantes deve ser observada uma técnica rigorosa. A padronização da técnica tem sido descrita como um fator importante a ser observado, devido à possibilidade de erros na avaliação óssea em função de projeções geométricas diferentes de uma mesma região (BRÄGGER et al., 1998; CHILVARQUER; CHILVARQUER, 2000; HOLLENDER; ROCKLER, 1980; JEFFCOAT, 1992).

A literatura descreve que as técnicas mais utilizadas são a radiografia periapical e a panorâmica (GRÖNDAHL; EKESTUBBE; GRÖNDAHL, 1996a), podendo também ser utilizada a técnica tomográfica (LUDLOW et al., 1995; LUDLOW; GATES; NASON JR, 1995).

A radiografia mais indicada é a intrabucal pela técnica do paralelismo, cone longo, com o feixe de raios $\mathrm{X}$ direcionado perpendicularmente ao implante e o filme posicionado sem dobras ou curvaturas, paralelo ao implante (GRÖNDAHL; EKESTUBBE; GRÖNDAHL, 1996b; HOLLENDER, 1992; SMITH; ZARB, 1989; STRID, 1985).

Nos implantes rosqueáveis os passos das espiras servem como referência para a mensuração da altura óssea e possibilitam alterações na angulação vertical para melhor obtenção das imagens das estruturas perimplantares.

Os implantes rosqueáveis tipo Brånemark utilizados neste estudo favorecem a padronização da projeção geométrica em função da presença dos passos das espiras (GRÖNDAHL ; EKESTUBBE; GRÖNDAHL, 1996b; HOLLENDER, 1992).

Para a padronização da tomada radiográfica em relação ao fator geométrico, diversos autores utilizam suportes padrão (BAHAT, 2000; BRÅNEMARK et al., 1977; 
STRID, 1985), modificação em suporte pré-fabricado (BRÄGGER et al., 1998; NICOPOULOU-KARAYIANNI et al., 1991), enquanto outros autores desenvolveram suporte porta filme para ser adaptado ao abutment do implante (COX; PHAROAH, 1986; MEIJER; STEEN; BOSMAN, 1992). A necessidade de remoção da prótese fixa do implante e a confecção de suportes individuais, inviabilizam a utilização de suportes especiais para acompanhamento longitudinal (HOLLENDER, 1992).

As radiografias intrabucais foram realizadas em nosso trabalho utilizando-se de suporte padrão para a região anterior Hanshin (Hanshin Technical Laboratory, Ltdinishinomiya, Japão) sem modificação. A padronização da tomada radiográfica em relação ao fator geométrico foi obtida pela utilização de ângulo horizontal perpendicular ao pilar do implantes (inspeção clínica) e ângulo vertical perpendicular ao implante, verificado na imagem das espiras dos implantes observada na radiografia.

Em relação à falta de padronização na angulação vertical quando da obtenção das radiografias, é interessante lembrar o trabalho de Sewerin, Gotfredsen e Stoltze (1997), em que concluíram que a projeção ortorradial (com variação de $10^{\circ}$ ) não influenciou a exatidão no diagnóstico da perda óssea perimplantar realizada diretamente sobre a radiografia, discordando em relação a outros autores (HOLLENDER; ROCKLER, 1980; SEWERIN, 1990).

Loftin et al. (1998), verificaram em estudos com chips ósseos, que os resultados quantitativos obtidos pela subtração radiográfica podem variar significativamente dependendo da forma da lesão, sendo que o posicionamento dos chips que atenuavam ao máximo o feixe de raios $\mathrm{X}$ resultam em melhor estimativa da massa óssea. 
Para a correção das imagens radiográficas causadas por erro no posicionamento geométrico, Webber, Ruttimann e Groenhuis (1984) desenvolveram metodologia baseada na localização de pontos de referência conhecidos dentro de uma imagem e pontos homólogos na outra imagem, permitindo então que as radiografias sejam sobrepostas e subtraídas.

A subtração radiográfica é um método mais sensitivo que a análise do filme periapical convencional para o diagnóstico das alterações ósseas (JEFFCOAT et al., 1996), necessitando de pares de radiografias padronizadas realizadas em exames diferentes, tanto no fator geométrico (angulação do feixe de raios $\mathrm{X}$ e posicionamento do filme e objeto) como no fator contraste (tempo de exposição e processamento) (BRÄGGER et al., 1991; BRÄGGER et al., 1992; JEFFCOAT, 1992; JEFFCOAT; REDDY, 1993; NICOPOULOU-KARAYIANNI et al., 1991; REDDY; JEFFCOAT; RICHARDSON, 1990).

Acreditamos que a limitação no método de subtração radiográfica seja a necessidade de obtenção de radiografias padronizadas principalmente no fator projeção geométrica, sendo que ocorre uma diminuição da sensibilidade e especificidade do método de subtração radiográfica com o aumento da variação do ângulo vertical.

O método digital para a correção das diferenças de contrastes a partir dos histogramas de tons de cinza de radiografias a serem subtraídas, apresentado por Ruttimann, Webber e Schmidt (1986) foi utilizado por diversos autores (BRÄGGER et al., 1991; FOURMOUSIS et al., 1994; NICOPOULOU-KARAYIANNI et al., 1991; REDDY; JEFFCOAT; RICHARDSON, 1990).

No trabalho aqui apresentado, a padronização da densidade radiográfica foi realizada utilizando-se sempre os mesmos parâmetros do aparelho de raios $\mathrm{X}$ para a 
execução da técnica (quilovoltagem, miliamperagem e tempo de exposição) e da processadora automática (tempo, temperatura de processamento e soluções processadoras), além da comparação entre os pares de radiografias realizada logo após o processamento por um radiologista experiente, ou seja, apto a realizar as alterações no ângulo vertical se necessárias, de acordo com os estudos de Gröndahl, Ekestubbe e Gröndahl (1996b) e Hollender e Rockler (1980), por meio de interpretação visual em negatoscópio auxiliado por lupa com cinco vezes de aumento, possibilitando a observação dos passos das espiras nitidamente nos dois lados do implante Se as espiras estivessem nítidas do lado direito mas difusas do lado esquerdo, outra tomada radiográfica foi executada aumentando a angulação vertical; e no caso em que a imagem das espiras estivessem difusas no lado direito e precisas no lado esquerdo, repetiu-se a radiografia diminuindo a angulação vertical dos raios X (GRÖNDAHL; EKESTUBBE; GRÖNDAHL, 1996b; HAYEK, 2002; HOLLENDER, 1992; HOLLENDER; ROCKLER, 1980).

A técnica cirúrgica empregada por Vasconcelos (2004), foi direcionada com o intuito de obter a maior estabilidade primária possível dos implantes, e foram instalados em osso de melhor qualidade, entretanto dificultou a obtenção de radiografias periapicais padronizadas, sendo que da amostra original foram retirados nove implantes por apresentarem dados discrepantes (espiras difusas) em algum período do controle realizado e três implantes que não obtiveram sucesso na osteointegração e foram removidos, não sendo realizado o controle radiográfico.

Observamos que os implantes perdidos estavam próximos ou intimamente relacionados com o seio maxilar e isso pode ter deixado os implantes distais com menor quantidade óssea ao seu redor e conseqüentemente, menor resistência às cargas mastigatórias (VASCONCELOS, 2004). 
As radiografias foram posteriormente digitalizadas por meio de microscópio ótico com 40 vezes de aumento, sendo que estas imagens foram analisadas pelo software ImageLab para a verificação de possíveis alterações na densidade ótica.

A utilização de escala de referência de alumínio (observada na literatura) quando da tomada radiográfica inicial para futura subtração radiográfica, não fornece dados para o ajuste de contraste e densidade da imagem, mas facilita o cálculo quantitativo das alterações ósseas (JEFFCOAT; REDDY, 1993).

Dentro das imagens a serem estudadas, devem-se estabelecer as regiões de interesse, sendo considerada área de controle onde não é esperada modificação e área de teste, região na qual pode ocorrer alteração (BRÄGGER et al.,1991).

A área de controle utilizada em nosso trabalho foi o implante, devido a sua alta densidade física, a qual confere menor variação da densidade ótica, favorecendo a análise das alterações ósseas (HAYEK, 2002; LOFTIN et al., 1998).

A área de interesse selecionada no trabalho foi na região cervical do implante e está de acordo com o que foi proposto por Strid (1985) e verificado por Collaert e De Bruyn (1998), que citaram que as primeiras alterações ósseas perimplantares ocorrem nas primeiras espiras do implante.

A utilização de gabarito para a seleção da área de controle (implante) e área de interesse (osso implante) facilitou a padronização para a análise das mesmas regiões em períodos distintos.

Para a correção de possíveis variações na densidade da radiografia e projeção geométrica oriundas da metodologia empregada, utilizamos uma equação matemática para validar a análise dos dados obtidos.

As variações encontradas entre as diferenças de densidade da região de interesse (osso + implante) em função da área de controle (implante), podem ser 
explicadas em parte pela possibilidade de terem ocorrido pequenas reabsorções no osso perimplantar e ou aumento da densidade óssea nos casos de sucesso do implante e à incidência de cargas mastigatórias funcionais (SMITH; ZARB, 1989; STRID, 1985).

A análise da freqüência de ressonância quantifica a estabilidade do implante por meio de uma medida, o quociente de estabilidade do implante, que varia de zero a 100. O número registrado é relativo à rigidez na interface osso implante e a quantidade de osso que circunda o implante (VASCONCELOS, 2004).

A avaliação dos implantes (que serviram para a nossa amostra) pelo aparelho OSSTELLTM demonstrou uma diferença estatisticamente significante entre os períodos T1 e T2 e entre T1 e T3, contudo não foi observada diferença estatisticamente significante entre os períodos T2 e T3 (VASCONCELOS, 2004).

Os resultados obtidos neste trabalho demonstraram também uma diferença estatisticamente significante entre os períodos T1 e T2 e entre T1 e T3, não existindo alteração estatisticamente significante entre os períodos T2 e T3.

Comparando a variação da densidade ótica ocorrida em trabalho pregresso realizado por Hayek (2002), aonde os implantes eram localizados na mandíbula e a perda óssea observada foi de $3 \%$ nos primeiros seis meses e de $4 \%$ nos primeiros 18 meses, a perda óssea observada no presente trabalho foi maior, sendo de $5 \%$ para o lado direito e de $6 \%$ para o lado esquerdo. No entanto devemos lembrar das diferenças anatômicas existentes entre a mandíbula na região entre os forames mentuais, na qual o osso é quase sempre de boa qualidade e a maxila, na qual o osso é mais variável e quase sempre menos denso do que a mandíbula.

A média da perda óssea ocorrida ao redor dos implantes, de acordo com os resultados obtidos por alguns autores (HAYEK, 2002; SOUZA PINTO, 2004; 
VASCONCELOS, 2004), ocorre com maior velocidade nos primeiros seis meses, estabilizando até os doze meses da instalação dos implantes e também foi observada nos dados obtidos em nossa amostra.

Esta comparação dos dados obtidos por meio da avaliação digital das radiografias periapicais da amostra de Vasconcelos (2004) com os dados obtidos por meio da análise da freqüência de ressonância, associada a avaliação clínica dos implantes, sugere que a metodologia empregada está correta e está compatível com o sucesso clínico observado. 


\section{CONCLUSÕES}

Após a análise dos dados obtidos neste trabalho, pode-se concluir que:

1. As radiografias periapicais padronizadas, realizadas imediatamente após a instalação da prótese, após seis meses e após doze meses e analisadas por meio de avaliação digital, demonstraram ser um método confiável, efetivo e reprodutivo;

2. A variação da densidade ótica na área de interesse (osso + implante) foi de aproximadamente $-5 \%$ para o lado direito e de aproximadamente $-6 \%$ para o lado esquerdo nos primeiros seis meses, quando da utilização da área de controle (implante);

3. Em média, a variação da densidade ótica que indicou perda óssea, foi observada com maior velocidade nos primeiros seis meses, estabilizando-se até os doze meses;

4. As variações encontradas entre as diferenças de densidade ótica da região de interesse (osso + implante) demonstraram coincidência com a análise da freqüência da ressonância e com o exame clínico dos implantes, demonstrando aspecto compatível com o sucesso dos implantes osteointegrados com função imediata, o que também é observado na literatura especializada. 


\section{REFERÊNCIAS ${ }^{1}$}

Adell R, Lekholm U, Rockler B, Brånemark P-I. A 15-year study of osseointegrated implants in the treatment of the edentulous jaw. Int J Oral Surg 1981;10(6):387-416.

Adell R, Lekholm U, Gröndahl K, Brånemark P-I, Lindström J, Jacobsson M. Reconstruction of severely resorbed edenttulous maxilae using osseointegrated fixtures in immediate autogenous bone grafts. Int J Oral Maxillofac Implants 1990;5(3):233-46.

Bahat O. Brånemark System Implants in the posterior maxilla: Clinical study of 660 implants followed for 5 to 12 years. Int J Oral Maxillofac Implants 2000;15(5):646-53.

Baxes GA. Digital image processing: A pratical primer, Prentice-Hall, Englewood Cliffs:, 1984. 187p.

Bogaerde LV, Pedretti G, Dellacasa P, Mozzati M, Rangert B. Early function of splinted implants in maxillas and posterior mandibles using Brånemark System machined-surface implants: an 18-month prospective clinical multicenter study. Clin Implant Dent Relat Res 2003; 5(1): 21-8.

Botter R C. Tratamento de dados em modelos de simulação discreta [Tese de LivreDocência]. São Paulo: Escola Politécnica da USP;2002.

Brägger U. Use of radiographs in evaluating success, stability and failure in implant dentistry. Periodontology 2000 1998;17:77-88.

Brägger U, Burgin W, Fourmoussis I, Lang NP. Image processing for the evaculation of dental implants. Dentomaxillofac Radiol 1992;21(4):208-12.

Brägger U, Burgin W, Fourmousis I, Schmid G, Schild U, Lang NP. Computerassisted densitometric image analysis of digital subtraction images: in vivo error of the method and effect of thresholding. J Periodontol 1998;69(9):967-74.

\footnotetext{
${ }^{1}$ De acordo com Estilo Vancouver. Abreviatura de periódicos segundo base de dados MEDLINE.
} 
Brägger U, Burgin W, Lang NP, Buser D. Digital subtraction radiography for the asssessment of changes in peri-implant bone density. Int $\mathrm{J}$ Oral Maxillofac Implants $1991 ; 6(2): 160-6$.

Brånemark P-I The Brånemark novum protocol for same-day teeth: a global perspective. Berlin: Quintessenz Verlags; 2001.

Brånemark P-I, Engstrand P, Öhrnell L-O, Gröndahl K, Nilsson P, Hagberg K, et al. Brånemark Novum: A new treatment concept for rehabilitation of the edentulous mandible. Preliminary results from a prospective clinical follow-up study. Clin Implant Dent Res 1999;1(1):2-16.

Brånemark P-I, Hansson BO, Adell R, Breine U, Lindström J, Hallén O et al. Osseointegrated implants in the treatment of the edentulous jaw. Experience from a 10-year period. Scand J Plast Surg 1977;16(Suppl):1-132.

Brunsky JB. Biomechanical factors affecting the boné-dental implant surface: Review paper. Clin Mater 1992;10(3):153-220.

Calandriello R, Tomatis M, Rangert B. Immediate functional loading of Brånemark System implants with enhanced initial stability: a prospective 1 - to 2 - year clinical and radiographic study. Clin Implant Dent Relat Res 2003;5(1)10-20.

Chilvarquer I. A radiologia e seus avanços contemporâneos. Rev Assoc Paul Cir Dent 1993;47(2):1001-4.

Chilvarquer I. A partir de quanto tempo após a cirurgia para colocação dos implantes uma imagem radiográfica pode ser conclusiva para avaliar a osseointegração. Rev Assoc Paul Cir Dent 1997:51(3):275-6.

Chilvarquer I, Chilvarquer LW. Tecnologia de ponta em imagenologia. In: Feller C, Gorab R. Atualização na clínica odontológica. Artes Médicas: São Paulo; 2000;41531.

Collaert B, De Bruyn H. Comparison of Brånemark fixture integration and short-term survival using one-stage or two-stage durgery in completely and partially edentulous mandibles. Clin Oral Implants Res 1998;9(2):131-5.

Constantino A. Osteocompressão. Otimizando a estabilidade primária para a ativação imediata de implantes. Implant News 2004;1(3):219-26. 
Cox JF, Pharoah M. An Alternative holder for radiographic avalation of tissueintegrated prostheses. J Prosthet Dent 1986;56(3):338-41.

Fourmousis I, Brägger U, Bürgin W, Tonetti M, Lang NP. Digital image processing. Part I. Evaluation of gray level correction methods in vitro. Clin Oral Implants Res 1994;5(1)37-47.

Francischone CE. Função ou carga imediata? Implant News 2004;1(1):16-7.

Gottlow J, Lundgren A. Cenni storici e anallisi della letteratura. In: Chiapasco L. et al. Osteointegrazione e carico imediato: Fondamenti biologici e applicazione cliniche. Milano: Masson S.p.A. 2002;1-18.

Gröndahl K, EKestubbe A, Gröndahl H-G. The Digora® image plate system. In: Gröndahl K, Ekestubbe A, Gröndahl H-G. Radiography in oral endosseous prosthetics, Nobel Biocare AB: Göteborg; 1996a;47-56.

Gröndahl K, Ekestubbe A, Gröndahl H-G. Postopertaive radiographic examinations. In: Gröndahl K, Ekestubbe A, Gröndahl H-G. Radiography in oral endosseous prosthetics Nobel Biocare AB: Göteborg; 1996b;111-26.

Hayek JE. Avaliação da densidade ótica perimplantar cervical em controle longitudinal [Dissertação de Mestrado]. São Paulo: Faculdade de Odontologia da USP; 2002.

Hollender L. Radiographic examination of endosseous implants in the jaws. In: Worthington P, Brånemark P-I. Advanced osseointegration surgery: applications in the maxillofacial region, Chicago: Quintessence, 1992;80-93.

Hollender L, Rockler B. Radiographic evaluation of osseointegrated implants of the jaws. Dentomaxillofac Radiol 1980;9(2)91-5.

Jeffcoat MK. Digital radiology for implant treatment planning and evaluation. Dentomaxilllofac Radiol 1992;21(4):203-7.

Jeffcoat MK, Reddy MS. Digital subtraction radiography for longitudinal assessment of peri-implant bone change: method and validation. Adv Dent Res 1993;7(2):196201. 
Jeffcoat MK, Reddy MS, Magnusson I, Johnson B, Meredith MP, Cavanaugh JrPF. et al. Efficacy of quantitative digital subtraction radiography using radiographs exposed in a multicenter trial. J Periodont Res 1996;31:157- 60.

Kullendorff B, Nilsson M. Diagnostic accuracy of direct digital dental radiography for the detection of periapical bone lesions II: Effects on diagnostic accuracy after application of image processing. Oral Surg Oral Med Oral Pathol Oral Radiol Endod 1996;82(5):585-9.

Kullendorff B, Nilsson M, Rohlin M. Diagnostic accuracy of direct digital dental radiography for the detection of periapical bone lesions: overall comparison between conventional and direct digital radiography. Oral Surg Oral Med Oral Pathol Oral Radiol Endod 1996;82(3):344-50.

Lekholm U, Zarb GA. Patient selection and preparation in: Brånemark P-I, Zarb GA. Tissue integrated prostheses osseointegration in clinical dentistry. Berlin;1985. cap.12, p.199-209.

Lenharo A, Cosso F. Carga imediata em um único elemento dental. Um protocolo de duas horas. Implant News 2004;1(2):145-52.

Loftin R, Webber R, Horton R, Tyndall D, Moriartry J. Effect of projective aspect variations on estimates of changes in bone mass using digital subtraction radiography. J Periodont Res 1998;33:352-8.

Ludlow JB, Gates W, Nason Jr RH. Radiographic evaluation os implant-obscured bone. Comparison of digitally subtracted tomographic and periapical techniques. Oral Surg Oral Med Oral Pathol Oral Radiol Endod 1995;80(3):351-7.

Ludlow JB, Nason Jr RH, Hutchens Jr LH, Moriarty J. Radiographic evaluation of alveolar crest obscured by dental implants. Implant Dent Dentistry 1995;4(1):13-8.

Meijer HJA, Steen WHA, Bosman F. Standardized radiographs os the alveolar crest arouns implants in the mandible. J Prosthet Dent 1992;68(2):318-21.

Nary Filho H, Francischone Jr CE, Cunha HA, Francischone CE, Sartori IAM, Nary PE. Sistema IOL de prótese provisória em protocolo inferior com carga imediata. Relato de caso clínico. Implant News 2004;1(3):209-16. 
Nicopoulou-Karayianni K, Brägger U, Burgin W, Nielsen PM, Lang NP. Diagnosis of alveolar bone changes with digital subtraction images and conventional radiographs. Oral Surg Oral Med Oral Pathol 1991;72:251-6.

Oliveira RR, Novaes Jr AB, Muglia VA, Souza SLS, Taba Jr M, Grisi MFM, et al. Nova geração de implantes osseointegráveis. A busca das melhores características para carga imediata. Implant News 2004;1(2):129-33.

Reddy MS, Jeffcoat MK, Richardson RC. Assessment of adjunctive flurbiprofen, therapy in root-form implant healing with digital subtraction radiography. J Oral Implantol 1990;16(40):272-6.

Rocci A, Martignoni M, Gottlow J. Immediate loading of Brånemark System ${ }^{\circledR}$ TiUnite? And machined-surface implants of posterior mandible: a randomized open-ended clinical trial. J Clin Implant Dent Rel Res 2003;5(1):57-65.

Ruttimann UE, Webber RL, Schmidt E. A robust digital method for film contrast correction in subtraction radiography. J Periodontal Res 1986;21(5):486-95.

Schnitman PA, Wohrle PS, Rubenstein JE. Immediate fixed interim prostheses supported by two-stage threated implants: methodology and results. J Oral Implantol 1990;16(2):96-105.

Sewerin IP. Errors in radiographic assessment of marginal bone height around osseointegrated implants. Scand J Dent Res 1990;98(5):428-33.

Sewerin IP, Gotfredsen K, Stoltze K. Accuracy of radiographic diagnosis of periimplant radiolucencies - an in vitro experiment. Clin Oral Implants Res 1997;299304.

Smith DE, Zarb GA. Criteria for success of osseointegrated endosseous implants. J Prosthet Dent 1989;62(5):567-72.

Souza Pinto AV. Avaliação clínica e radiográfica de implantes osseointegráveis instalados na mandíbula posterior e submetidos a um protocolo de função oclusal precoce [Tese de Doutorado]. Araçatuba: Faculdade de Odontologia da UNESP; 2004. 
Stenström B, Karlsson L, Matsheko G, Henrikson CO. Radiation dose in the surface jayer around osseointegrated titanium implants [abstract]. Dentomaxillofac Radiol 1990;19:44.

Strid K-G. Radiographic Procedures. In: Brånemark P-I, Zarb GA, Albrektsson T. Tissue-integrated prosthesis. Osseointegration in clinical dentistry 1985:317-327.

Tortamano Neto P, Camargo LOA, Veiga JL. Critérios clínicos de estabilidade inicial e qualidade óssea para o carregamento imediato de implantes osseointegrados. Implant News 2004;1(1):61-6.

Vale IS, Bramante AS, Bramante MC. Fator de distorção da placa ótica do sistema de imagem digital Digora. Rev Assoc Paul Cir Dent 1998;52(4):280-2.

Van Der Stelt PF. Digital radiology using the Digora registration technic. Rev Belge Med Dent 1996;51(2):93-100.

Van Der Stelt PF, Geraets WG. Computer-aided interpretation and quantification of angular periodontal bone defects on dental radiographs. IEEE Trans Biomed Eng 1991;38(4):334-8.

Vasconcelos LW. Avaliação clínica, pelo método da freqüência de ressonância, de implantes instalados por meio de técnica cirúrgica modificada na maxila e submetidos à função oclusal imediata [Tese de Doutorado]. Araçatuba: Faculdade de Odontologia da UNESP; 2004.

Vasconcelos LW, Petrilli G, Vasconcelos RCB, Kobayashi F, Carvalho RS. Função imediata em mandíbula: simplificação da técnica. Implant News 2005;2(2):147-52.

Vedovato E, Chilvarquer I. Overdenture (sobredentadura): como e quando? In: Dinato JC; Polido WD. Implantes ósseointegrados. São Paulo: Artes Médicas; 2001. cap. 11 , p. 190-213.

Viegas VN, Mossini MC, Cauduro FS, Gallina C. Carga imediata em região maxilar posterior. Implant News 2004;1(6):461-6.

Webber RL, Ruttimann UE, Groenhuis RA.J Computer correction of projective distortions in dental radiographs. J Dent Res 1984;63(8):1032-103. 
Wenzel A. Influence of computerized information technologies on image quality in dental radiographs. Tandlaegebladet 1991;95(12):527-59.

Winer BJ. Statistical Principles in Experimental Design. 2ed. Tokyo: McGraw-Hill; 1971. 
ANEXO A - Parecer de aprovaçáo do Comte de Ética em Pesquisa da Faculdade de Odontologia da Universidade de Săo Paulo - Protocolo 168/04

\section{UNIVERSIDADE DESADO PAUTO \\ FACULDAEELE OMONTOLOGA}

\section{PARECER DE APROVAÇÃO \\ Protocolo 168/04}

O Grupo de Trabalho indicado pelo Comitê de Ética em Pesquisa, APROVOU o protocolo de pesquisa "Avaliação da densidade ótica perimplantar cervical em controle longitudinal de implantes de carga imediata realizados em maxila", de responsabilidade do Pesquisador Jorge Elie Hayek, sob orientação do Prof. Dr. Israel Chilvarquer.

Tendo em vista a legislaçăo vigente, devem ser encaminhados a este Comitê relatórios anuais referentes ao andamento da pesquisa e ao término cópia do trabalho em "cd". Qualquer emenda do projeto original deve ser apresentada a este CEP para apreciaçăo, de forma clara e sucinta, identificando a parte do protocolo a ser modificada e suas justificativas.

Săo Paulo, 14 de outubro de 2004

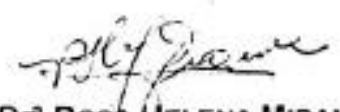

Profa Dra Rosa Helena Miranda Grande

Coordenadora do CEP-FOUSP 
APÊNDICE A - mensuração das densidades óticas realizadas imediatamente após a instalação da prótese

\begin{tabular}{|c|c|c|c|c|c|}
\hline & Implantes & T1DI & T1DOI & T1EI & T1EOI \\
\hline 1 & $\mathrm{~A} 1$ & 210 & 142 & 210 & 163 \\
\hline 2 & A2 & 215 & 145 & 194 & 165 \\
\hline 3 & A4 & 218 & 165 & 217 & 145 \\
\hline 4 & A5 & 207 & 148 & 212 & 158 \\
\hline \begin{tabular}{l|l}
5 \\
\end{tabular} & A6 & 197 & 147 & 202 & 151 \\
\hline \begin{tabular}{l|l|}
6 \\
\end{tabular} & B1 & 205 & 145 & 212 & 162 \\
\hline 7 & B2 & 197 & 134 & 212 & 156 \\
\hline 8 & B3 & 211 & 141 & 211 & 174 \\
\hline 9 & C1 & 220 & 145 & 218 & 144 \\
\hline 10 & C4 & 211 & 140 & 208 & 161 \\
\hline 11 & D1 & 212 & 161 & 209 & 163 \\
\hline 12 & $\mathrm{D} 2$ & 197 & 143 & 209 & 159 \\
\hline 13 & D3 & 205 & 137 & 206 & 177 \\
\hline 14 & D4 & 226 & 143 & 216 & 151 \\
\hline 15 & D6 & 215 & 133 & 219 & 155 \\
\hline 16 & $\mathrm{E} 1$ & 221 & 137 & 214 & 146 \\
\hline 17 & E2 & 199 & 135 & 240 & 148 \\
\hline 18 & E3 & 195 & 149 & 212 & 151 \\
\hline 19 & E4 & 198 & 133 & 209 & 163 \\
\hline 20 & E5 & 191 & 130 & 206 & 153 \\
\hline 21 & E6 & 209 & 127 & 206 & 144 \\
\hline 22 & F1 & 215 & 147 & 208 & 152 \\
\hline 23 & F2 & 213 & 130 & 227 & 146 \\
\hline 24 & F4 & 202 & 152 & 229 & 143 \\
\hline 25 & F5 & 215 & 127 & 213 & 159 \\
\hline 26 & F6 & 214 & 136 & 217 & 157 \\
\hline 27 & G1 & 196 & 150 & 202 & 165 \\
\hline 28 & G2 & 199 & 137 & 193 & 164 \\
\hline 29 & G3 & 211 & 145 & 211 & 132 \\
\hline 30 & G5 & 207 & 155 & 208 & 134 \\
\hline 31 & G6 & 212 & 151 & 198 & 147 \\
\hline 32 & $\mathrm{H} 1$ & 211 & 150 & 201 & 149 \\
\hline 33 & $\mathrm{H} 2$ & 195 & 164 & 207 & 156 \\
\hline 34 & $\mathrm{H} 3$ & 202 & 162 & 196 & 162 \\
\hline 35 & $\mathrm{H} 4$ & 214 & 135 & 217 & 158 \\
\hline 36 & $\mathrm{H} 5$ & 228 & 163 & 202 & 136 \\
\hline 37 & $\mathrm{H} 6$ & 217 & 151 & 216 & 157 \\
\hline 38 & 11 & 212 & 140 & 240 & 147 \\
\hline 39 & 13 & 195 & 145 & 206 & 158 \\
\hline \begin{tabular}{|l|}
40 \\
\end{tabular} & 14 & 199 & 164 & 198 & 170 \\
\hline 41 & 15 & 221 & 159 & 227 & 157 \\
\hline 42 & 16 & 200 & 155 & 203 & 154 \\
\hline \begin{tabular}{ll|}
43 \\
\end{tabular} & J1 & 201 & 155 & 208 & 156 \\
\hline 44 & $\mathrm{~J} 2$ & 226 & 153 & 215 & 144 \\
\hline 45 & $\mathrm{~J} 3$ & 220 & 157 & 213 & 152 \\
\hline 46 & J4 & 223 & 159 & 214 & 150 \\
\hline 47 & J5 & 205 & 135 & 206 & 163 \\
\hline \begin{tabular}{|l|}
48 \\
\end{tabular} & J6 & 196 & 144 & 208 & 168 \\
\hline
\end{tabular}


APÊNDICE B - mensuração das densidades óticas realizadas 6 meses após a instalação da prótese

\begin{tabular}{|c|c|c|c|c|c|}
\hline & Implantes & T2DI & T2DOI & T2EI & T2EOI \\
\hline 1 & A1 & 229 & 143 & 208 & 158 \\
\hline 2 & A2 & 222 & 138 & 222 & 173 \\
\hline 3 & A4 & 218 & 160 & 224 & 143 \\
\hline 4 & A5 & 220 & 157 & 226 & 144 \\
\hline 5 & A6 & 220 & 148 & 238 & 144 \\
\hline 6 & B1 & 206 & 149 & 221 & 164 \\
\hline 7 & B2 & 214 & 133 & 218 & 158 \\
\hline 8 & B3 & 214 & 130 & 216 & 167 \\
\hline 9 & C1 & 218 & 143 & 216 & 142 \\
\hline 10 & C4 & 211 & 123 & 213 & 152 \\
\hline 11 & D1 & 206 & 128 & 212 & 148 \\
\hline 12 & D2 & 202 & 137 & 211 & 163 \\
\hline 13 & D3 & 193 & 135 & 198 & 161 \\
\hline 14 & D4 & 219 & 125 & 216 & 149 \\
\hline 15 & D6 & 189 & 135 & 202 & 143 \\
\hline 16 & E1 & 219 & 128 & 225 & 146 \\
\hline 17 & E2 & 201 & 135 & 220 & 144 \\
\hline 18 & E3 & 195 & 142 & 213 & 146 \\
\hline 19 & E4 & 207 & 130 & 208 & 158 \\
\hline 20 & E5 & 226 & 124 & 229 & 150 \\
\hline 21 & E6 & 217 & 129 & 227 & 144 \\
\hline 22 & F1 & 211 & 119 & 213 & 147 \\
\hline 23 & $\mathrm{~F} 2$ & 230 & 120 & 242 & 150 \\
\hline 24 & F4 & 192 & 132 & 217 & 129 \\
\hline 25 & $\mathrm{~F} 5$ & 218 & 137 & 216 & 153 \\
\hline 26 & F6 & 211 & 122 & 224 & 153 \\
\hline 27 & G1 & 207 & 144 & 223 & 150 \\
\hline 28 & G2 & 217 & 154 & 205 & 158 \\
\hline 29 & G3 & 230 & 145 & 229 & 135 \\
\hline 30 & G5 & 199 & 144 & 226 & 142 \\
\hline 31 & G6 & 231 & 152 & 204 & 143 \\
\hline 32 & $\mathrm{H} 1$ & 227 & 154 & 226 & 156 \\
\hline 33 & $\mathrm{H} 2$ & 195 & 168 & 208 & 150 \\
\hline 34 & $\mathrm{H} 3$ & 208 & 150 & 198 & 159 \\
\hline 35 & $\mathrm{H} 4$ & 237 & 162 & 219 & 155 \\
\hline 36 & $\mathrm{H} 5$ & 207 & 145 & 232 & 154 \\
\hline 37 & $\mathrm{H} 6$ & 212 & 143 & 214 & 149 \\
\hline 38 & 11 & 222 & 155 & 239 & 133 \\
\hline 39 & 13 & 197 & 149 & 207 & 152 \\
\hline 40 & 14 & 199 & 148 & 199 & 154 \\
\hline 41 & 15 & 201 & 131 & 221 & 144 \\
\hline 42 & 16 & 188 & 141 & 206 & 151 \\
\hline 43 & J1 & 215 & 153 & 227 & 151 \\
\hline 44 & $\mathrm{~J} 2$ & 232 & 146 & 241 & 158 \\
\hline 45 & J3 & 233 & 166 & 240 & 154 \\
\hline 46 & J4 & 237 & 145 & 235 & 142 \\
\hline 47 & $\mathrm{J5}$ & 237 & 137 & 243 & 180 \\
\hline 48 & $\mathrm{~J} 6$ & 194 & 136 & 234 & 178 \\
\hline
\end{tabular}


APÊNDICE C - mensuração das densidades óticas realizadas 12 meses após a colocação da prótese

\begin{tabular}{|c|c|c|c|c|c|}
\hline & Implantes & T3DI & T3DOI & T3EI & T3EOI \\
\hline 1 & $\mathrm{~A} 1$ & 219 & 136 & 199 & 157 \\
\hline 2 & A2 & 224 & 138 & 228 & 163 \\
\hline 3 & A4 & 217 & 155 & 216 & 143 \\
\hline 4 & A5 & 215 & 145 & 208 & 154 \\
\hline 5 & A6 & 213 & 149 & 227 & 145 \\
\hline \begin{tabular}{l|l}
6 \\
\end{tabular} & B1 & 202 & 151 & 227 & 140 \\
\hline 7 & B2 & 190 & 117 & 211 & 152 \\
\hline 8 & B3 & 204 & 135 & 206 & 148 \\
\hline 9 & C1 & 202 & 130 & 196 & 128 \\
\hline 10 & $\mathrm{C} 4$ & 200 & 117 & 199 & 154 \\
\hline 11 & D1 & 203 & 126 & 210 & 146 \\
\hline 12 & $\mathrm{D} 2$ & 191 & 131 & 202 & 160 \\
\hline 13 & D3 & 200 & 137 & 204 & 156 \\
\hline 14 & D4 & 229 & 129 & 218 & 153 \\
\hline 15 & D6 & 218 & 131 & 220 & 153 \\
\hline 16 & E1 & 223 & 126 & 224 & 143 \\
\hline 17 & E2 & 215 & 146 & 229 & 146 \\
\hline 18 & E3 & 199 & 154 & 210 & 138 \\
\hline 19 & E4 & 201 & 129 & 210 & 158 \\
\hline 20 & E5 & 209 & 122 & 222 & 153 \\
\hline 21 & E6 & 200 & 134 & 211 & 149 \\
\hline 22 & F1 & 206 & 120 & 212 & 144 \\
\hline 23 & F2 & 210 & 121 & 228 & 144 \\
\hline 24 & F4 & 195 & 144 & 214 & 127 \\
\hline 25 & F5 & 225 & 127 & 227 & 155 \\
\hline 26 & F6 & 216 & 121 & 232 & 165 \\
\hline 27 & G1 & 196 & 136 & 214 & 166 \\
\hline 28 & G2 & 217 & 155 & 198 & 155 \\
\hline 29 & G3 & 207 & 135 & 219 & 126 \\
\hline 30 & G5 & 213 & 153 & 230 & 141 \\
\hline 31 & G6 & 231 & 167 & 198 & 136 \\
\hline 32 & $\mathrm{H} 1$ & 227 & 144 & 213 & 150 \\
\hline 33 & $\mathrm{H} 2$ & 208 & 168 & 220 & 155 \\
\hline 34 & $\mathrm{H} 3$ & 212 & 156 & 197 & 165 \\
\hline 35 & $\mathrm{H} 4$ & 227 & 154 & 221 & 152 \\
\hline 36 & $\mathrm{H} 5$ & 229 & 148 & 216 & 139 \\
\hline 37 & $\mathrm{H} 6$ & 198 & 137 & 216 & 156 \\
\hline 38 & 11 & 219 & 136 & 232 & 122 \\
\hline 39 & 13 & 190 & 139 & 217 & 160 \\
\hline 40 & 14 & 190 & 140 & 211 & 156 \\
\hline 41 & 15 & 205 & 137 & 211 & 139 \\
\hline 42 & 16 & 198 & 145 & 211 & 154 \\
\hline 43 & $\mathrm{~J} 1$ & 221 & 154 & 212 & 168 \\
\hline 44 & $\mathrm{~J} 2$ & 232 & 152 & 211 & 145 \\
\hline 45 & J3 & 223 & 159 & 222 & 141 \\
\hline 46 & J4 & 231 & 140 & 219 & 128 \\
\hline 47 & $\mathrm{~J} 5$ & 229 & 137 & 238 & 175 \\
\hline 48 & J6 & 218 & 166 & 217 & 147 \\
\hline
\end{tabular}


APÊNDICE D - mensuração das densidades óticas corrigidas realizadas imediatamente após a colocação da prótese

\begin{tabular}{|c|c|c|c|c|c|}
\hline & Implantes & Por T1DI & T1DOICor & Por T1EI & T1EOICor \\
\hline 1 & $\overline{\mathrm{A} 1}$ & 1,39 & 148 & 1,02 & 160 \\
\hline 2 & A2 & 1,37 & 149 & 0,90 & 183 \\
\hline 3 & A4 & 1,52 & 165 & 0,99 & 146 \\
\hline 4 & A5 & 1,40 & 153 & 0,98 & 160 \\
\hline 5 & $\mathrm{~A} 6$ & 1,47 & 157 & 0,91 & 166 \\
\hline 6 & $\mathrm{~B} 1$ & 1,44 & 145 & 0,96 & 168 \\
\hline 7 & B2 & 1,25 & 136 & 0,99 & 153 \\
\hline 8 & B3 & 1,38 & 140 & 1,00 & 174 \\
\hline 9 & $\mathrm{C} 1$ & 1,57 & 141 & 1,04 & 140 \\
\hline 10 & C4 & 1,30 & 138 & 1,01 & 156 \\
\hline 11 & D1 & 1,39 & 157 & 0,99 & 162 \\
\hline 12 & D2 & 1,19 & 143 & 1,01 & 156 \\
\hline 13 & D3 & 1,28 & 133 & 1,02 & 174 \\
\hline 14 & $\mathrm{D} 4$ & 1,50 & 142 & 1,00 & 151 \\
\hline 15 & D6 & 1,42 & 128 & 1,02 & 151 \\
\hline 16 & $\mathrm{E} 1$ & 1,56 & 137 & 0,97 & 151 \\
\hline 17 & E2 & 1,47 & 139 & 1,04 & 142 \\
\hline 18 & E3 & 1,44 & 150 & 1,00 & 151 \\
\hline 19 & E4 & 1,27 & 136 & 1,00 & 164 \\
\hline 20 & E5 & 1,37 & 142 & 0,94 & 163 \\
\hline 21 & E6 & 1,34 & 127 & 0,96 & 150 \\
\hline 22 & $\mathrm{~F} 1$ & 1,43 & 144 & 0,99 & 151 \\
\hline 23 & F2 & 1,46 & 133 & 0,98 & 149 \\
\hline 24 & $\mathrm{~F} 4$ & 1,54 & 148 & 1,04 & 137 \\
\hline 25 & F5 & 1,45 & 130 & 0,97 & 163 \\
\hline 26 & F6 & 1,31 & 136 & 0,97 & 162 \\
\hline 27 & $\mathrm{G} 1$ & 1,18 & 153 & 0,95 & 174 \\
\hline 28 & G2 & 1,40 & 145 & 0,97 & 169 \\
\hline 29 & G3 & 1,64 & 148 & 0,96 & 137 \\
\hline 30 & G5 & 1,51 & 155 & 0,94 & 143 \\
\hline 31 & G6 & 1,70 & 160 & 0,99 & 148 \\
\hline 32 & $\mathrm{H} 1$ & 1,51 & 158 & 0,94 & 158 \\
\hline 33 & $\mathrm{H} 2$ & 1,34 & 168 & 0,98 & 160 \\
\hline 34 & $\mathrm{H} 3$ & 1,28 & 166 & 0,99 & 163 \\
\hline 35 & $\mathrm{H} 4$ & 1,49 & 143 & 0,99 & 159 \\
\hline 36 & $\mathrm{H} 5$ & 1,65 & 158 & 0,93 & 146 \\
\hline 37 & $\mathrm{H} 6$ & 1,27 & 145 & 1,00 & 157 \\
\hline 38 & 11 & 1,80 & 144 & 1,01 & 145 \\
\hline 39 & 13 & 1,19 & 144 & 0,98 & 161 \\
\hline 40 & 14 & 1,22 & 162 & 0,98 & 174 \\
\hline 41 & 15 & 1,47 & 150 & 1,03 & 152 \\
\hline 42 & 16 & 1,29 & 151 & 0,98 & 157 \\
\hline 43 & $\mathrm{~J} 1$ & 1,32 & 164 & 0,96 & 162 \\
\hline 44 & $\mathrm{~J} 2$ & 1,60 & 156 & 0,97 & 149 \\
\hline 45 & $\mathrm{~J} 3$ & 1,58 & 161 & 0,95 & 161 \\
\hline 46 & $\mathrm{~J} 4$ & 1,80 & 164 & 0,96 & 156 \\
\hline 47 & $\mathrm{~J} 5$ & 1,31 & 147 & 0,90 & 181 \\
\hline 48 & $\mathrm{~J} 6$ & 1,48 & 149 & 0,95 & 177 \\
\hline
\end{tabular}


APÊNDICE E - mensuração das densidades óticas corrigidas realizadas 6 meses após a colocação da prótese e variação percentual na área de interesse osso + implante nos primeiros 6 meses

\begin{tabular}{|c|c|c|c|c|c|c|c|}
\hline & Implantes & Por T2DI & T2DOICor & Por T2EI & T2EOICor & P1DOI & P1EOI \\
\hline 1 & $\mathrm{~A} 1$ & 1,37 & 137 & 1,01 & 156 & $-0,08$ & $-0,02$ \\
\hline 2 & A2 & 1,52 & 137 & 1,03 & 167 & $-0,08$ & $-0,08$ \\
\hline 3 & A4 & 1,53 & 160 & 1,02 & 140 & $-0,03$ & $-0,04$ \\
\hline 4 & A5 & 1,42 & 153 & 1,05 & 137 & 0,00 & $-0,15$ \\
\hline 5 & A6 & 1,62 & 144 & 1,07 & 135 & $-0,08$ & $-0,19$ \\
\hline 6 & $\mathrm{~B} 1$ & 1,50 & 148 & 1,00 & 163 & 0,02 & $-0,03$ \\
\hline 7 & B2 & 1,26 & 125 & 1,02 & 155 & $-0,09$ & 0,01 \\
\hline \begin{tabular}{l|l}
8 \\
\end{tabular} & B3 & 1,38 & 127 & 1,02 & 163 & $-0,09$ & $-0,06$ \\
\hline 9 & C1 & 0,01 & 140 & 1,03 & 138 & 0,00 & $-0,01$ \\
\hline 10 & $\mathrm{C} 4$ & 1,29 & 121 & 1,03 & 147 & $-0,12$ & $-0,06$ \\
\hline 11 & D1 & 1,40 & 129 & 1,01 & 147 & $-0,18$ & $-0,09$ \\
\hline 12 & D2 & 1,18 & 133 & 1,02 & 160 & $-0,07$ & 0,03 \\
\hline 13 & D3 & 1,26 & 139 & 0,98 & 165 & 0,05 & $-0,05$ \\
\hline 14 & D4 & 1,50 & 128 & 1,00 & 142 & $-0,10$ & $-0,06$ \\
\hline 15 & D6 & 1,39 & 148 & 0,95 & 149 & 0,15 & $-0,01$ \\
\hline 16 & E1 & 1,61 & 129 & 1,02 & 143 & $-0,06$ & $-0,05$ \\
\hline 17 & E2 & 1,41 & 138 & 0,96 & 150 & $-0,01$ & 0,06 \\
\hline 18 & E3 & 1,44 & 143 & 1,01 & 145 & $-0,05$ & $-0,04$ \\
\hline 19 & E4 & 1,27 & 127 & 1,00 & 157 & $-0,07$ & $-0,04$ \\
\hline 20 & E5 & 1,45 & 120 & 1,05 & 143 & $-0,15$ & $-0,12$ \\
\hline 21 & E6 & 1,40 & 124 & 1,06 & 136 & $-0,02$ & $-0,09$ \\
\hline 22 & $\mathrm{~F} 1$ & 0,01 & 119 & 1,01 & 146 & $-0,18$ & $-0,03$ \\
\hline 23 & F2 & 1,49 & 114 & 1,04 & 144 & $-0,15$ & $-0,04$ \\
\hline 24 & $\mathrm{~F} 4$ & 1,48 & 135 & 0,99 & 131 & $-0,09$ & $-0,05$ \\
\hline 25 & F5 & 1,49 & 138 & 0,99 & 155 & 0,06 & $-0,05$ \\
\hline 26 & F6 & 1,35 & 124 & 1,00 & 153 & $-0,09$ & $-0,06$ \\
\hline 27 & G1 & 1,25 & 139 & 1,05 & 143 & $-0,09$ & $-0,18$ \\
\hline 28 & G2 & 1,44 & 150 & 1,03 & 153 & 0,03 & $-0,09$ \\
\hline 29 & G3 & 1,71 & 136 & 1,04 & 129 & $-0,08$ & $-0,06$ \\
\hline 30 & G5 & 1,60 & 149 & 1,02 & 139 & $-0,03$ & $-0,03$ \\
\hline 31 & G6 & 1,71 & 148 & 1,02 & 140 & $-0,08$ & $-0,06$ \\
\hline 32 & $\mathrm{H} 1$ & 1,61 & 150 & 1,06 & 147 & $-0,05$ & $-0,07$ \\
\hline 33 & $\mathrm{H} 2$ & 1,37 & 172 & 0,98 & 153 & 0,02 & $-0,04$ \\
\hline 34 & $\mathrm{H} 3$ & 1,29 & 150 & 1,01 & 158 & $-0,10$ & $-0,03$ \\
\hline 35 & $\mathrm{H} 4$ & 1,51 & 154 & 1,00 & 155 & 0,08 & $-0,03$ \\
\hline 36 & $\mathrm{H} 5$ & 1,77 & 155 & 1,07 & 144 & $-0,02$ & $-0,01$ \\
\hline 37 & $\mathrm{H} 6$ & 1,27 & 141 & 0,99 & 150 & $-0,03$ & $-0,04$ \\
\hline 38 & 11 & 1,78 & 152 & 1,01 & 132 & 0,06 & $-0,09$ \\
\hline 39 & 13 & 1,21 & 147 & 0,99 & 154 & 0,02 & $-0,04$ \\
\hline 40 & 14 & 1,25 & 146 & 0,98 & 157 & $-0,10$ & $-0,10$ \\
\hline 41 & 15 & 1,43 & 136 & 1,01 & 143 & $-0,09$ & $-0,06$ \\
\hline 42 & 16 & 1,31 & 147 & 1,00 & 152 & $-0,03$ & $-0,03$ \\
\hline 43 & $\mathrm{~J} 1$ & 1,36 & 151 & 1,05 & 143 & $-0,08$ & $-0,11$ \\
\hline 44 & $\mathrm{~J} 2$ & 1,65 & 145 & 1,08 & 146 & $-0,07$ & $-0,02$ \\
\hline 45 & J3 & 1,67 & 161 & 1,07 & 144 & 0,00 & $-0,10$ \\
\hline 46 & $\mathrm{~J} 4$ & 1,87 & 141 & 1,06 & 135 & $-0,14$ & $-0,14$ \\
\hline 47 & $\mathrm{~J} 5$ & 1,46 & 133 & 1,06 & 170 & $-0,10$ & $-0,06$ \\
\hline 48 & J6 & 1,57 & 142 & 1,07 & 167 & $-0,05$ & $-0,06$ \\
\hline
\end{tabular}


APÊNDICE F - mensuração das densidades óticas corrigidas realizadas 12 meses após a colocação da prótese e variação percentual na área de interesse osso+implante nos últimos 12 meses

\begin{tabular}{|c|c|c|c|c|c|c|c|}
\hline & Implantes & Por T3DI & T3DOICor & T3EOICor & Por T3EI & P2DOI & P2EOI \\
\hline 1 & $\mathrm{~A} 1$ & 1,00 & 136 & 162 & 0,97 & $-0,08$ & 0,02 \\
\hline 2 & A2 & 1,02 & 136 & 153 & 1,06 & $-0,09$ & $-0,16$ \\
\hline 3 & A4 & 1,00 & 155 & 145 & 0,99 & $-0,06$ & $-0,01$ \\
\hline 4 & A5 & 1,00 & 144 & 159 & 0,97 & $-0,06$ & $-0,01$ \\
\hline 5 & A6 & 1,01 & 147 & 142 & 1,02 & $-0,06$ & $-0,15$ \\
\hline 6 & B1 & 0,99 & 153 & 136 & 1,03 & 0,06 & $-0,19$ \\
\hline 7 & $\mathrm{~B} 2$ & 0,95 & 124 & 154 & 0,99 & $-0,09$ & 0,01 \\
\hline 8 & B3 & 0,97 & 139 & 152 & 0,98 & $-0,01$ & $-0,13$ \\
\hline 9 & C1 & 0,95 & 138 & 137 & 0,93 & $-0,02$ & $-0,02$ \\
\hline 10 & C4 & 0,96 & 122 & 160 & 0,96 & $-0,12$ & 0,02 \\
\hline 11 & D1 & 0,98 & 129 & 146 & 1,00 & $-0,18$ & $-0,10$ \\
\hline 12 & $\mathrm{D} 2$ & 0,97 & 135 & 164 & 0,97 & $-0,05$ & 0,05 \\
\hline 13 & D3 & 1,00 & 137 & 155 & 1,01 & 0,02 & $-0,11$ \\
\hline 14 & D4 & 1,02 & 127 & 142 & 1,01 & $-0,11$ & $-0,06$ \\
\hline 15 & D6 & 1,05 & 125 & 149 & 1,03 & $-0,03$ & $-0,02$ \\
\hline 16 & E1 & 1,01 & 125 & 141 & 1,01 & $-0,09$ & $-0,07$ \\
\hline 17 & E2 & 1,05 & 139 & 146 & 1,00 & 0,00 & 0,03 \\
\hline 18 & E3 & 1,01 & 152 & 139 & 0,99 & 0,01 & $-0,08$ \\
\hline 19 & E4 & 1,00 & 130 & 157 & 1,00 & $-0,04$ & $-0,04$ \\
\hline 20 & E5 & 1,00 & 122 & 151 & 1,01 & $-0,14$ & $-0,07$ \\
\hline 21 & E6 & 0,96 & 140 & 152 & 0,98 & 0,10 & 0,01 \\
\hline 22 & F1 & 0,98 & 123 & 143 & 1,00 & $-0,15$ & $-0,05$ \\
\hline 23 & F2 & 0,96 & 125 & 147 & 0,98 & $-0,06$ & $-0,02$ \\
\hline 24 & F4 & 0,99 & 145 & 130 & 0,97 & $-0,02$ & $-0,05$ \\
\hline 25 & F5 & 1,03 & 124 & 149 & 1,04 & $-0,04$ & $-0,09$ \\
\hline 26 & F6 & 1,01 & 120 & 160 & 1,03 & $-0,12$ & $-0,02$ \\
\hline 27 & G1 & 0,98 & 139 & 165 & 1,00 & $-0,09$ & $-0,05$ \\
\hline 28 & G2 & 1,03 & 151 & 156 & 1,00 & 0,04 & $-0,08$ \\
\hline 29 & G3 & 0,96 & 141 & 126 & 1,00 & $-0,05$ & $-0,08$ \\
\hline 30 & G5 & 1,03 & 148 & 136 & 1,04 & $-0,04$ & $-0,05$ \\
\hline 31 & G6 & 1,03 & 163 & 137 & 0,99 & 0,02 & $-0,07$ \\
\hline 32 & $\mathrm{H} 1$ & 1,02 & 141 & 150 & 1,00 & $-0,11$ & $-0,05$ \\
\hline 33 & $\mathrm{H} 2$ & 1,04 & 161 & 149 & 1,04 & $-0,04$ & $-0,07$ \\
\hline 34 & $\mathrm{H} 3$ & 1,02 & 153 & 155 & 1,00 & $-0,08$ & $-0,05$ \\
\hline 35 & $\mathrm{H} 4$ & 1,00 & 153 & 151 & 1,01 & 0,08 & $-0,06$ \\
\hline 36 & H5 & 1,03 & 143 & 140 & 1,00 & $-0,10$ & $-0,04$ \\
\hline 37 & $\mathrm{H} 6$ & 0,95 & 145 & 156 & 1,00 & $-0,01$ & $-0,01$ \\
\hline 38 & I1 & 1,01 & 135 & 124 & 0,98 & $-0,06$ & $-0,14$ \\
\hline 39 & 13 & 0,98 & 142 & 155 & 1,03 & $-0,02$ & $-0,04$ \\
\hline 40 & 14 & 0,97 & 144 & 150 & 1,04 & $-0,11$ & $-0,14$ \\
\hline 41 & 15 & 0,98 & 140 & 145 & 0,96 & $-0,07$ & $-0,05$ \\
\hline 42 & 16 & 1,01 & 143 & 151 & 1,02 & $-0,06$ & $-0,04$ \\
\hline 43 & $\mathrm{~J} 1$ & 1,04 & 148 & 141 & 0,98 & $-0,10$ & $-0,13$ \\
\hline 44 & J2 & 1,01 & 151 & 153 & 0,95 & $-0,03$ & 0,03 \\
\hline 45 & J3 & 0,99 & 161 & 143 & 0,99 & 0,00 & $-0,11$ \\
\hline 46 & $\mathrm{~J} 4$ & 1,00 & 140 & 130 & 0,98 & $-0,15$ & $-0,16$ \\
\hline 47 & $\mathrm{~J} 5$ & 1,02 & 140 & 168 & 1,04 & $-0,05$ & $-0,07$ \\
\hline 48 & J6 & 1,08 & 154 & 171 & 0,99 & 0,04 & $-0,04$ \\
\hline
\end{tabular}


